\title{
On the vasoprotective mechanisms underlying novel $\beta$-phosphorylated nitrones: focus on free radical characterization, scavenging and NO donation in a biological model of oxidative stress
}

Mathieu Cassien, Consuelo Petrocchi, Sophie Thétiot-Laurent, Maxime Robin, Emilie Ricquebourg, Chouaib Kandouli, Alice Asteian, Antal Rockenbauer, ${ }^{\dagger}$ Anne Mercier, Marcel Culcasi, and Sylvia Pietri*

Aix Marseille Université, CNRS, UMR 7273, Institut de Chimie Radicalaire, Equipe Sondes Moléculaires en Biologie et Stress Oxydant (SMBSO), Service 522, 13397, Marseille Cedex 20, France

${ }^{\dagger}$ Research Centre for Natural Sciences of the Hungarian Academy of Sciences, Institute of Materials and Environmental Chemistry, Budapest, Hungary and Budapest University of Technology and Economics, Hungary

*Corresponding author E-mail: sylvia.pietri@ univ-amu.fr

*To whom correspondence should be addressed.

Phone: +33 (0)4-91-28-85-79. Fax: +33 (0)4-91-28-87-58 


\section{ABSTRACT}

A series of new hybrid 2-(diethoxyphosphoryl)-N-(benzylidene)propan-2-amine oxide derivatives with different aromatic substitution (PPNs) were synthesized. These molecules were evaluated for their EPR spin trapping potential and NO donation properties in vitro, their cytotoxicity and on precontracted rat aortic rings. A subfamily of the new PPNs featured an antioxidant moiety occurring in natural phenolic acids. From the experimental screening of these hydroxyphenyl- and methoxyphenyl-substituted PPNs, biocompatible nitrones $\mathbf{4 d}, \mathbf{4 g}-\mathbf{i}$ deriving from caffeic, gallic, ferulic and sinapic acids, which combined improved EPR probing of ROS formation, vasorelaxant action and antioxidant potency, might be potential drug candidate alternatives to $\mathrm{PBN}$ and its analogues.

\section{Keywords}

$\beta$-Diethoxyphosphoryl nitrones, phenolic acids, antioxidant, NO donors, EPR spin trapping, aortic rings relaxation 


\section{Introduction}

Oxidative stress usually refers to an imbalance between cellular formation of reactive oxygen species (ROS), including free radicals (e.g., superoxide $\left(\mathrm{O}_{2^{*}}{ }^{-}\right)$and hydroxyl radicals $(\mathrm{HO} \cdot)$ ) and non-radical oxidants (e.g., hydrogen peroxide $\left(\mathrm{H}_{2} \mathrm{O}_{2}\right)$ or peroxynitrite), and efficacy of cell antioxidant defense machinery (e.g., superoxide dismutase, catalase, ascorbate) [1,2]. Many triggers of ROS formation have been identified, such as activation of endogenous enzymes (e.g., xanthine or NADPH oxidases) or exposure to UV light, ionizing radiations, toxins, cigarette smoke or environmental pollutants [1]. The concept of oxidative stress was recently re-defined as a disruption of redox signaling and control, a new perception that stimulated many investigations toward the role of cellular nucleophiles such as glutathione, or the identification of key enzymes perturbations [2-4]. Although it was now established that low levels of certain ROS can enhance cell defense capacity [2,5], there is a tremendous body of evidence from animal studies and clinical trials that a massive release of ROS contribute to the initiation and progression of a variety of chronic diseases such as inflammation, cancer, cardiovascular and neurodegenerative disorders, or acute iron overload-induced poisoning $[1,6]$.

In this context, the discovery of antioxidant molecules to regulate oxidative stress-related diseases has become a challenging area of pharmaceutical chemistry. In most investigations, the privileged targets are natural or synthetic substances having improved ability to (i) interrupt free radical-mediated chains of cell lipid peroxidation by scavenging free radicals or inactivating metal ions catalysts such as $\mathrm{Fe}^{2+}$ or (ii) retard or prevent new free radical chains to form, e.g., by decreasing local oxygen concentration [7-10]. Phenolic compounds $\mathrm{Ar}-\mathrm{OH}$ (many classes of them being abundant in plants) are the most effective antioxidants since they can meet some essential conditions of good chain-breaking antioxidants, i.e., (i) they are effective $\mathrm{H}$ donors due to relatively low $\mathrm{O}-\mathrm{H}$ bond dissociation energies, (ii) their interaction with propagating radicals, e.g., peroxyl radicals ROO·, forms unreactive, resonance-stabilized phenoxyl 
radicals $\mathrm{ArO} \cdot$, thus stopping peroxidation chains, (iii) they have ionization potentials high enough to prevent the formation of $\mathrm{O}_{2}{ }^{-}$from molecular oxygen by electron transfer, and (iv) they generally show suitable chemical properties such as iron chelation or increased lipophilicity to reach cell membranes $[7,8]$. In addition some of them were shown to inhibit initiating enzymes such as xanthine oxidase or directly scavenge the primarily formed $\mathrm{O}_{2} \bullet^{-}[1,7,8]$. Owing to these unique antioxidant properties, hundreds of natural and synthetic phenolics have been isolated or produced in the last 50 years and tested as inhibitors of oxidative stress and a further step to increase their biological efficacy would be to design multipotent hybrid compounds having additional sites for free radical scavenging.

Nitrones such as $\alpha$-phenyl- $N$-tert-butyl nitrone (PBN; Figure 1A) have been used extensively to characterize non-persistent free radicals using the EPR / spin trapping technique [11]. Three decades ago, Novelli and co-workers [12] opened the way to the therapeutic use of nitrones by reporting that i.p. administration of PBN efficiently decreased traumatic shock in rats. From then on, PBN and a growing number of its congeners have demonstrated biological activity in a variety of free radical-related disorders, including ischemia/reperfusion, brain or renal injury, retinal and neuronal damage [13]. Although the therapeutic efficacy of PBN-type nitrones (PBNs) in systems exposed to ROS may be consistently relevant to free radical scavenging, other mechanisms have been highlighted, such as iNOS and COX-2 gene induction suppression [14], modulation of phase II enzymes and caspase-3 activities [15] or activation of Ras-ERK pathway [16]. Moreover, in aqueous media, PBN [17] and other nitrones were shown to release nitric oxide (NO), a free radical implicated in both physiological and stressrelated signaling. Indeed, this chemical property of PBN is increasingly invoked to explain some of its pharmacological actions $[16,18]$. Among the increasing number of available PBNs designed for a therapeutic purpose, most were elaborated on the basis of cell targeting, bioavailability or increased membrane crossing $[13,19,20]$, and if a few were built around a phenolic-based antioxidant scaffold [2124] (Figure 1A), no further structural modification of the non aromatic side of the nitrone function was done to improve the EPR detection of spin adducts. 
In the search for biocompatible probes of oxidative stress acting both as antioxidants and EPR analytical tools, we describe herein the synthesis and biological evaluation of a new class of hybrid, natural product-inspired PBN derivatives bearing a diethoxyphosphoryl substituent on the $N$-alkyl arm. Because of the recognized antioxidant properties of food phenolics from diet, such as gallic, caffeic, ferulic and sinapic acids [25], and their implication in the prevention of many oxidative stress-related pathologies [26], their aromatic frameworks, which only contained hydroxy and methoxy substituents, were selected in the design of eight novel antioxidant-based nitrones (termed as PPNs; Figure 1B). The choice of incorporating a $\mathrm{P}(\mathrm{O})(\mathrm{OEt})_{2}$ group was motivated both by its high biocompatibility $[27,28]$ and the fact that $\mathrm{O}_{2}{ }^{-}$and $\mathrm{HO} \cdot$ spin adducts of the parent 2-(diethoxyphosphoryl)- $N$-(benzylidene)propan-2amine oxide (PPN) showed increased stabilities vs PBN in buffers [29].

In this paper, we first screened the new antioxidant-based PPNs using EPR spin trapping, spontaneous NO-releasing, lipophilicity, cytotoxicity and antioxidant endpoints, in comparison with relevant standards, PBN, PPN, and nine additional non phenolic PPNs, with seven of them being newly described (Figure 1B). In a second part of the study, PPNs with the best overall antioxidant and/or NO donation properties were tested in a model a free radical-challenged rat aortic rings both for their EPR detector properties and protective effect against vasorelaxant function impairment and protein carbonylation.

\section{Results and Discussion}

Chemistry and Crystallographic Analysis. The synthesis of the fifteen new PPNs was carried out using methodology developed for the synthesis of the unsubstituted PPN [30], with a few modifications for the first two steps (Scheme 1). Thus, the yield of $\beta$-phosphorylated amine 1 was increased up to 75\% by treating by $20 \% \mathrm{NaOH}$ the crude product dissolved in chloroform and further oxidation of 1 by 2 eq. $\mathrm{KMnO}_{4} / \mathrm{MgSO}_{4}$ gave the corresponding nitrophosphonate 2 in $70 \%$ yield. The key hydroxylamine 3 was then obtained by $\mathrm{Zn} / \mathrm{NH}_{4} \mathrm{Cl}$ reduction of $\mathbf{2}$ and PPNs $\mathbf{4 a}-\mathbf{r}$ (Figure 1B) were obtained in moderate to good yields by condensing the corresponding substituted benzaldehyde on $\mathbf{3}$ in THF or DCE at $100{ }^{\circ} \mathrm{C}$. 
Scheme 1. General Synthesis of PPNs $4 \mathbf{a}-\mathbf{r}^{a}$

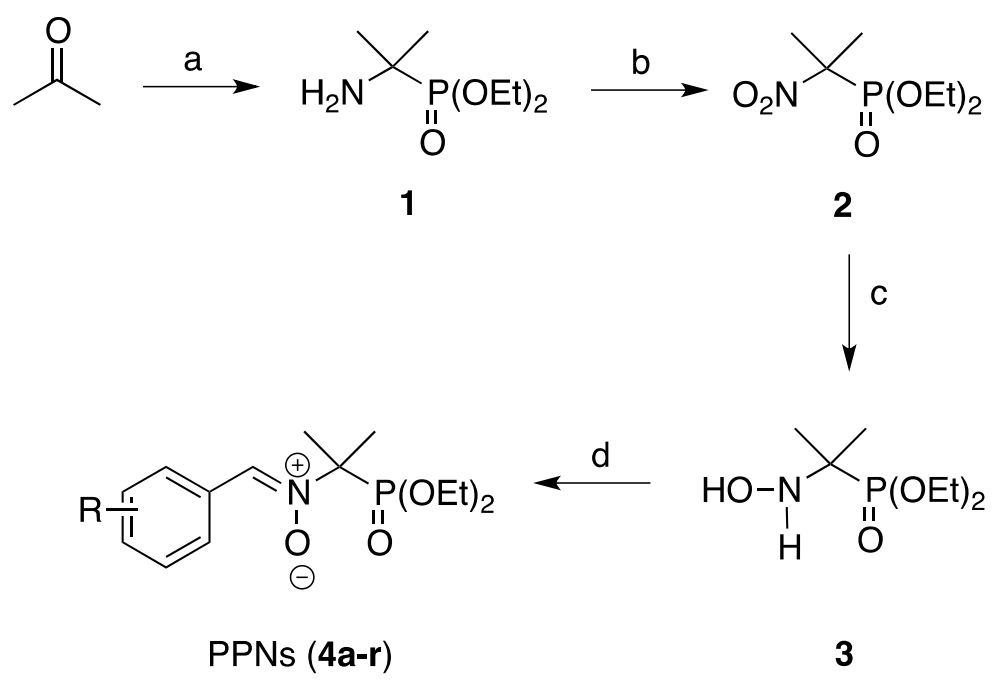

${ }^{a}$ Reagents and conditions: (a) $\mathrm{HP}(\mathrm{O})(\mathrm{OEt})_{2}, \mathrm{NH}_{3}$, acetone, $5{ }^{\circ} \mathrm{C}, 2 \mathrm{~h}, 75 \%$; (b) 2 eq $\mathrm{KMnO}_{4}, 2$ eq. $\mathrm{MgSO}_{4}$, acetone:water $(7.5: 1), 50-55{ }^{\circ} \mathrm{C}, 1$ day, $70 \%$; (c) $\mathrm{Zn}, \mathrm{NH}_{4} \mathrm{Cl}$, water, $-10{ }^{\circ} \mathrm{C}$, then $2 \mathrm{~h}$, room temp., then $50-55^{\circ} \mathrm{C}, 1 \mathrm{~h}, 53 \%$; (d) ArCHO, THF or DCE, $100{ }^{\circ} \mathrm{C}, 4 \mathrm{~h}, 32-87 \%$.

Nitrones $\mathbf{4 b}, \mathbf{4} \mathbf{f}, \mathbf{4 k}$ and $\mathbf{4 q}$, which were obtained as single crystals, were analyzed by X-ray diffraction. Selected crystal parameters are given in Table 1 and characteristic ORTEP drawings [31] with $50 \%$ probability displacement thermal ellipsoids are depicted in Figure 2 for $\mathbf{4 b}$ and $\mathbf{4 q}$. The four PPNs crystallized as $Z$-isomers, i.e., the aromatic ring and the $\left.\mathrm{N}^{+}\right)^{-}-\mathrm{O}^{-}$bond are in syn position, a geometry also found for 4-OH-PPN 4c [32]. Two types of intramolecular H-bonds toward the negatively charged oxygen of the nitrone function establish in $\mathbf{4 b}, \mathbf{4} \mathbf{k}$ and $\mathbf{4 q}$ (Figure 2 and Figure S1A in Supporting Information), i.e., one linking one ortho- $\mathrm{H}$ atom of the ring (in $\mathbf{4 b}$ and $\mathbf{4 k}$ ), and the other one linking one methylene hydrogen of the $\mathrm{P}(\mathrm{O})(\mathrm{OEt})_{2}$ group (in $\mathbf{4 k}$ and $\mathbf{4 q}$ ). Comparison of crystallographic data of the new PPNs vs $4 \mathbf{c}[32]$ also reveals even shorter $\mathrm{C}=\mathrm{N}$ bond distances in $\mathbf{4 f}$ and $\mathbf{4 q}$ (Table 1). In the case of compound $\mathbf{4 f}$ (which crystallises as $[\mathbf{4 f}-\mathbf{4 f}]$ and $\left[\mathbf{4 f}-\mathbf{4 f} \mathbf{f}^{\prime}\right]$ dimers with intermolecular $\pi-\pi$ and $\mathrm{CH}-\pi$ stacking interactions), a third type of intramolecular H-bond exist 
between the oxygen of the nitrone function and the hydroxyl group in ortho-position (Supporting Information, Figure S1B). As expected from the weak steric effect of meta substitution of the phenyl ring, the $\mathrm{C}=\mathrm{N}$ bond and the aromatic ring in $\mathbf{4 b}$ are nearly coplanar, allowing $\mathrm{C}(10)-\mathrm{P}(11)$ bond to preferentially occupy a position below the $\mathrm{C}(1)-\mathrm{N}(8)-\mathrm{O}(9)$ plane, with a $\mathrm{O}(9)-\mathrm{N}(8)-\mathrm{C}(10)-\mathrm{P}(11)$ dihedral angle close to $90^{\circ}$ (Figure 2A; see also Figure S1A for $4 \mathbf{k}$ ). Conversely, due to the high bulkiness of the 2,6-Me-Phenyl, a minimum steric interaction in $\mathbf{4 q}$ is obtained when both the $\mathrm{P}(\mathrm{O})(\mathrm{OEt})_{2}$ and the aromatic groups hinder almost equally the two faces of the $\mathrm{C}=\mathrm{N}$ spin trapping site (Figure 2B). Consistently, the high steric strain in $\mathbf{4 q}$ also resulted in the longest $\mathrm{C}(1)-\mathrm{C}(2)$ bond (Table 1). These steric-induced differences in both accessibility at $C(1)$ and $C(1)-C(2)$ bond lengths should affect the spin trapping and NO releasing properties of the PPNs, respectively (see below), although importance of solvation should be considered.

EPR Spin Trapping Studies. Note: to simplify, acronyms indicating aromatic substitution as indicated in Figure 1B were chosen to designate each of the PPNs and the related R radical spin adducts were termed as PPNs-R.

The spin trapping properties of the new PPNs were first investigated in vitro against a series of carbon-, nitrogen- and sulfur-centered radicals in water or phosphate buffer at near-neutral ( $\mathrm{pH} 7.4$; $\mathrm{nPB}$ ) or acidic $(\mathrm{pH} \sim 4$; acPB) $\mathrm{pH}$. In general, typical EPR spectra of nitroxides resulting from radical addition to PPNs retain the basic feature of PBNs spin adducts, i.e., a triplet of doublets (nitrogen $\left(a_{N}\right)$ and $\beta$-hydrogen $\left(\mathrm{a}_{\mathrm{H}}\right)$ couplings), with extra splitting by a large ${ }^{31} \mathrm{P} \beta$-coupling $\left(\mathrm{a}_{\mathrm{P}}\right)$. For the parent PPN and its hydroxy- and methoxy-substituted derivatives $\mathbf{4 a}-\mathbf{i}$, the hyperfine splitting constants (hfscs) extracted from computer simulation of the experimental EPR signals, together with some characteristic $g$-values of spin adducts, are listed in Table 2. To assess the importance of steric and electronic effects of aromatic substituents on hfscs, the trapping experiments were also carried out on PPNs $4 \mathbf{j}-\mathbf{p}$ substituted with electron-withdrawing groups or one ortho group (Table 3). Hence, for a given PPNs-R adduct, ortho/para substituents would increase spin density on nitrogen (which determines the 
magnitude of $\mathrm{a}_{\mathrm{N}}$ ) if they are electron-donating (such as hydroxy or methoxy groups), or conversely decrease $a_{N}$ if they are electron-withdrawing (such as nitro, acid or ester groups), while metasubstituents woud have no or little effect on $\mathrm{a}_{\mathrm{N}}$. This tendency was actually observed among PPNs-R adducts but, compared to the corresponding adducts with PPN itself, $\mathrm{a}_{\mathrm{N}}$ values were affected to a modest extent, not exceeding +0.03 and $-0.05 \mathrm{mT}$ for electron-donating (Table 2) or withdrawing (Table 3) groups, respectively.

Even for nitrones scarcely soluble in aqueous media, rather intense and long-lasting signals were detected when the sulfur trioxide anion radical $\left(\mathrm{SO}_{3}{ }^{-}\right)$or carbon-centered radicals were trapped in $\mathrm{nPB}$, an improved stability reported for the few previously tested PPNs [29,30,32]. As anticipated from its Xray structure revealing high steric effect around the nitrone function (Figure 2B), most spin trapping experiments on 2,6-Me-PPN 4q were unsuccessful, with the notable exception of $\mathrm{CO}_{2}{ }^{-}$which added to the nitrone to yield a weak composite signal containing the expected 2,6-Me-PPN-CO $2 \mathrm{H}$ adduct, with $\mathrm{a}_{\mathrm{N}}$ $=1.467 ; \mathrm{a}_{\mathrm{H}}=0.702 ; \mathrm{a}_{\mathrm{P}}=4.112 \mathrm{mT}$, and $\sim 50 \%$ of a decomposition triplet $\left(\mathrm{a}_{\mathrm{N}}=1.628 \mathrm{mT}\right)$.

Regardless of the trapped species, the largest $\mathrm{a}_{\mathrm{H}}$ values were found among the other ortho-substituted PPNs 4a,f, j,p, indicating that steric hindrance increases spin density on the $\beta$-hydrogen. The same trend was reported for hindered adducts of nitrones carrying two ortho-substituents such as 2,4,6-OMe-PBN [33] and 2,4,6-OMe-PPN [30]. For a given PPNs, both $\mathrm{a}_{\mathrm{H}}$ and $\mathrm{a}_{\mathrm{P}}$ augmented with decreasing size of the trapped alkyl radical, yielding significant differences in the spectrum total width (STW) [29]. Thus, going from methyl radical to the bulkier $\alpha$-hydroxyethyl radical led to a STW decrease of $c a$. $0.65 \mathrm{mT}$ for antioxidant-based PPNs (4d, $\mathbf{4 g}-\mathbf{i})$, a value reaching 0.80 and $1.18 \mathrm{mT}$ for ortho-substituted $\mathbf{4 a}$ and 4p, respectively. A STW difference of $0.75 \mathrm{mT}$ has been reported earlier between the $\mathrm{CO}_{2} \bullet^{-}$spin adducts of 3- and 4-pyridyl substituted PPNs [30] which cannot originate from a change in steric hindrance. Here, PPNs- $\mathrm{CO}_{2} \mathrm{H}$ adducts of $\mathrm{NO}_{2}$ - and $\mathrm{OH}$-substituted nitrones showed even larger STW differences, e.g., it was $+0.93 \mathrm{mT}$ between 4-OH-PPN 4c and 2-OH-PPN 4a (Table 2) and +1.13 mT between 4$\mathrm{NO}_{2}$-PPN $4 \mathbf{l}$ and 2-NO $-\mathrm{PPN}$ 4j (Table 3) and both cases it was spin density at phosphorus which 


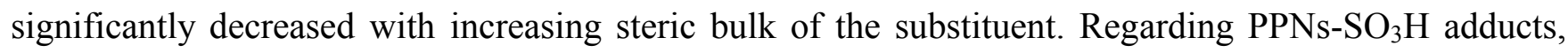
which were reported here for the first time, we found no straightforward explanation to interpret the interplay between nitrone structure and $\left(\mathrm{a}_{\mathrm{H}}, \mathrm{a}_{\mathrm{P}}\right)$ variations. Again, strong STW differences were found among these spin adducts, e.g., it was of $6.85 \mathrm{mT}$ for $2-\mathrm{CF}_{3}-\mathrm{PPN}_{-} \mathrm{SO}_{3} \mathrm{H}$ and $7.33 \mathrm{mT}$ for $4-\mathrm{OH}-3,5-$ OMe-PPN-SO ${ }_{3} \mathrm{H}$ with ap values as different as 3.990 and $4.479 \mathrm{mT}$, respectively (Figure $3 \mathrm{~A}, \mathrm{~B}$ ).

Contrary to the trapping experiments described above, only a limited number of PPNs gave detectable PPNs-N ${ }_{3}$ or PPNs-H adducts in aqueous media, the latter being formed by $\mathrm{NaBH}_{4}$ reduction of the nitrone (Table 3). Expectedly, azidyl radical $\left(\mathrm{N}_{3} \cdot\right)$ spin adducts exhibited an additional long-range nitrogen coupling such as in PPN-N ${ }_{3}\left(a_{N}=1.397 ; \mathrm{a}_{\mathrm{H}}=0.221 ; \mathrm{a}_{\mathrm{P}}=4.475\right.$ and $\left.\mathrm{a}_{\mathrm{N} \beta}=0.181 \mathrm{mT}\right)$ while in PPNs-H spectral simulations were in agreement with two equivalent $\beta$-hydrogen hfscs (for PPN-H: $\mathrm{a}_{\mathrm{N}}=$ $\left.1.534 ; \mathrm{a}_{\mathrm{H}}=1.061(2 \mathrm{H}) ; \mathrm{a}_{\mathrm{P}}=4.851 \mathrm{mT}\right)$.

We next examined if the new PPNs could form EPR detectable spin adducts with oxygen-centered radicals in aqueous environment and for this purpose we used PPN, 4-NO 2 -PPN $4 \mathbf{l}$ and 4-Cl-PPN 4r as benchmarks since their $\mathrm{O}_{2}{ }^{-}, \mathrm{HO} \cdot$ and $\mathrm{CH}_{3} \mathrm{O} \cdot$ spin adducts were characterized previously $[29,30,34]$. To generate $\mathrm{O}_{2} \bullet^{-} / \mathrm{HOO} \cdot$ in aqueous milieu, we used alternatively a xanthine/xanthine oxidase system in nPB or UV-photolysis of $30 \% \mathrm{H}_{2} \mathrm{O}_{2}$ in water and, in our hands, PPN was the only nitrone that yielded moderately stable PPN-OOH with both systems, with hfscs from the enzymatic (photolytic) generator of: $\mathrm{a}_{\mathrm{N}}=1.359(1.366), \mathrm{a}_{\mathrm{H}}=0.226(0.235)$, and $\mathrm{a}_{\mathrm{P}}=4.129(4.173) \mathrm{mT}$. Photolytically generated HOO• radicals gave rather strong PPNs-OOH EPR signals with all non-phenolic PPNs (Figure 3C), whose hfscs are in agreement with those of PPN-OOH [30], and which again showed a dramatic increase in $\mathrm{a}_{\mathrm{H}}$ value with steric hindrance, as in $\mathbf{4} \mathbf{j}$ and $\mathbf{4 p}$ (Table 3 ). However, such addition of HOO in aqueous medium failed to yield detectable levels of PPNs-OOH signals in the particular case of hydroxy- and methoxy-substituted PPNs 4a-i. However, using nucleophilic addition of $\mathrm{H}_{2} \mathrm{O}_{2}$ in a polar aprotic solvent such as pyridine as a means to produce PPNs-OOH, the expected EPR signals having $g$-values $\sim 2.0060$ were observed for most of the tested PPNs (Tables 2 and 3), with the notable exception of 4-OH-3,5- 
OMe-PPN 4i which afforded a transient decomposition spectrum, whose simulated couplings are compatible with the corresponding $\beta$-phosphorylated benzoyl nitroxide PPNsOX-1 (i.e., 4-OH-3,5OMe-PPNsOX) where, due its $\operatorname{Ar}-\mathrm{C}(\mathrm{O})-\mathrm{N}(\mathrm{O} \cdot)$ structure, spin density is delocalized through the aromatic ring $\left(\right.$ hfscs: $\mathrm{a}_{\mathrm{N}}=0.500 ; \mathrm{a}_{\mathrm{P}}=0.932 ; \mathrm{a}_{\text {ortho-H }}(2 \mathrm{H})=0.371 ; \mathrm{a}_{\mathrm{H}-\mathrm{OMe}}(6 \mathrm{H})=0.177 ; \mathrm{a}_{\mathrm{H}-\mathrm{para}-\mathrm{OH}}=0.090$ $\mathrm{mT} ; \mathrm{g}=2.0062$; Figure S2 in Supporting Information).

In another hand, when $\mathrm{HO} \cdot$ radicals were generated by a Fenton reaction in acPB only PPN and a few nitrones among compounds $\mathbf{4} \mathbf{j}-\mathbf{r}$, but none of the antioxidant-based PPNs $\mathbf{4 a}-\mathbf{i}$, yielded PPNs-OH adducts. EPR signals lasted only a few minutes, showing $g$-values of $\sim 2.0057$ and hfscs summarized in Table 3 in agreement with literature data for the $\mathrm{HO}$ adducts of 4-Cl-PPN 4r and 4-NO $-\mathrm{PPN} 4 \mathbf{l}$ $[29,30]$. Thus, we obtained for PPN-OH at $\mathrm{pH} 4.5: \mathrm{a}_{\mathrm{N}}=1.426 ; \mathrm{a}_{\mathrm{H}}=0.248 ; \mathrm{a}_{\mathrm{P}}=4.313 \mathrm{mT} ; \mathrm{g}=2.00561$. From our observations and similar reported earlier [29,30], the presence of a $\mathrm{P}(\mathrm{O})(\mathrm{OEt})_{2}$ group in the PPNs structure did result in an increase of PPNs-OH stability vs PBNs-OH (e.g., half-life of PBN-OH in buffer is only $90 \mathrm{~s}$ at $\mathrm{pH} 6$ [35]), but this effect has not yet been quantified to our knowledge.

In marked contrast with $\mathrm{HO} \cdot$, long-lasting methoxy radical adducts $\mathrm{PPNs}-\mathrm{OCH}_{3}$ were easily detected in DMSO/methanol $(75: 25)$ solution with most of the tested PPNs using the reaction of lead tetraacetate with the alcohol followed by aerial oxidation as the free radical generator (Figure 3D). One must notice that in this system antioxidant-based nitrones $\mathbf{4 g}$ and $\mathbf{4 i}$ yielded the benzoyl nitroxides PPNsOX-2,3, respectively instead of the expected adduct (Tables 2 and 3). Despite they both arise from nitrone 4i the observed strong difference in EPR spectrum shapes and hfses strongly suggest PPNsOX1 and PPNsOX3 are different species. Until now only a few other $\mathrm{PPNs}_{-} \mathrm{OCH}_{3}$ adducts have been described in the literature $[32,34]$.

In the spin trapping respect, the lack of detection of $\mathrm{O}_{2}{ }^{-} / \mathrm{HO} \cdot$ adducts of antioxidant-constructed nitrones 4a-i, which like other PPNs yet contain a stabilizing $\mathrm{P}(\mathrm{O})(\mathrm{OEt})_{2}$ group, may be a consequence of preferential attack on the phenolic sites rather than on the nitrone function. Hence, the reaction of bulky RO• radicals on BHT-PBN (Figure 1) in benzene selectively yielded the persistent, di-ortho-tert- 
butyl protected phenoxyl radical ArO while the normal nitroxide spin adduct was seen alone upon addition of carbon-centered radicals [36]. Our EPR data therefore suggest that the phenoxyl radicals arising from nitrones $\mathbf{4 a}-\mathbf{i}$, which have a lower steric protection, decay too fast to allow EPR detection and are not spin trapped.

EPR Measurement of NO Release from PPNs. We then turned our attention to the potential NOreleasing properties of PPNs in water and for this purpose we used the water soluble nitrosyl-Fe(II) complex of $N$-methyl- $D$-glucamide dithiocarbamate (MGD), [Fe(II)- $\left.\mathrm{MGD}_{2}\right]$ as a trap for NO. When a saturated aqueous solution of 4-Cl-PPN 4r ( $\mathrm{pH} 6.58)$ was UV-photolyzed in the dark for 10 min in the presence of a solution of $\left[\mathrm{Fe}(\mathrm{II})-\mathrm{MGD}_{2}\right]$ prepared as described in the Experimental Section, the characteristic EPR triplet of $\left[\mathrm{Fe}(\mathrm{II})-\mathrm{MGD}_{2}-\mathrm{NO}\right]$ [37] was detected at room temperature, with $\mathrm{a}_{\mathrm{N}}=$ $1.269 \mathrm{mT}$ and $\mathrm{g}_{\text {iso }}=2.0418$, identical to that recorded from $20 \mathrm{mM}$ sodium nitrite $\left(\mathrm{NaNO}_{2}\right)$, an inorganic NO donor. The NO-derived EPR triplet from $4 \mathbf{r}$ increased with photolysis time, reaching a maximum after $\sim 1 \mathrm{~h}$ (final $\mathrm{pH} 6.56$ ), while additional signals appeared (Figure 4A), corresponding to an alkyl radical adduct $\left(\mathrm{a}_{\mathrm{N}}=1.464 ; \mathrm{a}_{\mathrm{H}}=0.297 ; \mathrm{a}_{\mathrm{P}}=4.349 \mathrm{mT} ; \mathrm{g}=2.0071\right)$ and a decomposition triplet $\left(\mathrm{a}_{\mathrm{N}}=\right.$ $1.623 \mathrm{mT} ; \mathrm{g}=2.0069)$. The same radical mixture with similar EPR intensities was observed when aqueous $4 \mathbf{r}$ was allowed to stand in ambient light for $4.5 \mathrm{~h}$ (not shown), consistent with a spontaneous NO release in aqueous environment.

To systematically compare the magnitude of this NO-releasing property among tested nitrones, they were photolyzed for 70 min under complete solubility conditions (i.e., at $20 \mathrm{mM}$ ) and the relative $\left[\mathrm{Fe}(\mathrm{II})-\mathrm{MGD}_{2}-\mathrm{NO}\right]$ concentrations and $\mathrm{pH}$ variation were compared to that $0.1 \mathrm{mM}$ sodium nitroprusside dihydrate (SNP), a widely used NO donor. As shown in Figure 4B, NO release significantly varied with PPNs structure, and the greatest effect was found for nitrones $\mathbf{4 q}, \mathbf{j}, \mathbf{p}$ whose aryl groups bear the bulkiest ortho-substituents. During most experiments a typical benzaldehyde's smell developed in test tubes and maximal $\mathrm{pH}$ variations were within instrumental error (i.e., $0.03 \mathrm{pH}$ units). PBN was the weakest NO donor while decomposition of SNP in water, even at a 200-fold lower 
concentration, yielded $2 \times 10^{4}$ times greater amounts of NO relative to the best PPNs. On the basis of the reported mechanisms of NO release from aqueous spin traps, including PBN [17,37], a similar behavior for PPNs can be postulated where the $\mathrm{C}(1)-\mathrm{N}(8)$ bond of the primarily formed hydroxylamine 5 cleaves to give a benzaldehyde and the $\beta$-phosphorylated nitroso compound $\mathbf{6}$ as the actual photolytic source of NO (Figure 5). In agreement, performing the NO-trapping assay on synthesized nitroso 6 (0.1 M) allowed to detect the Fe(II)-nitrosyl complex after only 10 min of photolysis but in this case a very strong triplet $\left(\mathrm{a}_{\mathrm{N}}=1.612 ; \mathrm{a}_{13-\mathrm{C}}=0.60 \mathrm{mT} ; \mathrm{g}=2.0066\right)$ was the major EPR signal. To rule out any additional role of the phosphorylated moiety in NO-donation by PPNs, we found no EPR signal when the assay was carried out on the $\beta$-phosphorylated amino analogue 7 (Figure 5, inset).

Altogether, the increased NO-releasing power for the bulkiest PPNs and a mechanism such as that shown in Figure 5 suggest a possible correlation between substitution at $\mathrm{C}(3), \mathrm{C}(7)$ and the $\mathrm{C}(1)-\mathrm{N}(8)$ bond length of the key intermediate $\mathbf{5}$, which should cleave more easily as this bond is lengthened. Figure $4 \mathrm{~B}$ shows the $\mathrm{C}(1)-\mathrm{N}(8)$ distances determined after modeling and optimization of the geometry using HyperChem 8.0 software (Autodesk, Inc.). Although the hydroxylamines from all orthosubstituted PPNs had signifiantly longer $\mathrm{C}(1)-\mathrm{N}(8)$ bonds even for small $\mathrm{OH}$ groups, the relationship with trapped NO amounts was not straightforward, as exemplified by PPN (Figure 4B). Experimental studies [38] and density functional theory (DFT) calculations [39,40] have established $\beta$-cleavage of the $\mathrm{C}-\mathrm{N}$ bond as a major step leading to $\mathrm{NO}$ release and affecting stability of $\mathrm{O}_{2}{ }^{-}$and $\mathrm{HO} \cdot$ nitroxide spin adducts of phosphorylated cyclic nitrones. Regarding linear PPNs, a DFT study has proposed alternative mechanisms for the unimolecular decomposition of 4-OH-PPN-OOH adduct involving intramolecular H-bonds and nonbonding interactions [32], yet without excluding this may ultimately proceed via NO release.

Antioxidant Activity of PPNs Derivatives. The antioxidant properties of PPNs were assessed using three standard assays, i.e., scavenging of 1,1'-diphenyl-2-picrylhydrazyl (DPPH) in methanol, determination of the total reactive antioxidant potential (TRAP) in DMSO (2\%)-supplemented Tris-HCl 
buffer ( $\mathrm{pH}$ 7.4) and quenching of $\mathrm{O}_{2}{ }^{-}$in glycine buffer (pH 10) [41-43]. As most PPNs did not yield PPNs-OOH EPR signals upon xanthine oxidase-based generation of $\mathrm{O}_{2} \bullet^{-}$(see above), we also investigated whether this enzyme is inhibited by these nitrones. Experimental details for all antioxidant studies are provided in Supporting Information. The results are shown in Table 4 and are compared to the parent PBN and PPN nitrones, four natural product-based phenolic acids whose aromatic framework was used to build compounds $\mathbf{4 d}, \mathbf{g}-\mathbf{i}$, and two standard antioxidants, the flavonol quercetin and Trolox, a water-soluble vitamin E analogue.

$D P P H$ reducing capacity of PPNs. Measuring the decay at $517 \mathrm{~nm}$ of the stable nitrogen radical DPPH in a polar organic solvent has been routinely used to probe the radical scavenging property of phenolic antioxidants which can react with the divalent $\mathrm{N}$ atom of DPPH [44]. The mechanism involves reduction of DPPH by a formal H-atom transfer reaction from the aromatic hydroxy groups $[10,41,44]$. Accordingly, mixing DPPH (0.13 $\mathrm{mM}$ in methanol) for $3 \mathrm{~min}$ with PBN, PPN or its non-phenolic derivatives $\mathbf{4 j}-\mathbf{q}(5 \mu \mathrm{M}-1 \mathrm{mM})$ did not result in a significant absorption decrease, giving $\mathrm{EC}_{50}$ values $>$ $1 \mathrm{mM}$ (defined as the concentration necessary to halve DPPH concentration). Among phenolic PPNs, the strong DPPH scavenging activities of gallic and caffeic acids, both incorporating a 3,4-OH pattern, were well translated to their analogues $\mathbf{4 g}$ and $\mathbf{4 d}$, respectively, with $\mathrm{EC}_{50} \sim 10-20 \mu \mathrm{M}$ similar to that of Trolox and quercetin. Introduction of one or two methoxy substituents to the 4-OH phenolic structure, such as in nitrones $\mathbf{4 h}$ and $\mathbf{4 i}$, slightly decreased the activity in the assay, which yet remained $4-5$ times lower than that observed in the analogues ferulic and sinapic acids, respectively. Lastly, monohydroxylated PPNs $4 \mathbf{a}-\mathbf{c}$ and the other phenolic nitrones lacking the 3,4-OH catechol pattern 4 e,f did not significantly scavenge DPPH. The present results are consistent with general structural features promoting the antioxidant activity of phenolic acids [25] and literature data reporting that DPPH scavenging activity of hydroxycinnamic acid derivatives is enhanced by the presence of either a 3,4-OH pattern $[25,45]$ or electron donors such as methoxy groups in ortho position to a 4-OH group [46]. 
TRAP Assay. To determine the TRAP (expressed in Trolox equivalents (TE), i.e., TRAP $=1$ for Trolox) of PPNs $(1-30 \mu \mathrm{M})$, we used the concentration-dependent inhibition of luminol $(13 \mu \mathrm{M})$ chemiluminescence as a probe of ROO radical formation during the decomposition of 2,2'-azobis(2amidinopropane) dihydrochloride (AAPH, $150 \mathrm{mM}$ ) at $37^{\circ} \mathrm{C}$. If $\mathrm{OH}$ groups in phenolic antioxidants are privileged targets for AAPH-derived peroxyl radicals [10,25,41,44], additional trapping at the nitrone site of PPNs may synergistically participate in the TRAP. However, PBN, PPN and all non-phenolic PPNs (with the exception of the ester nitrone 4o) had virtually no TRAP, a result also reported for PBN and some non phenolic $N$-alkyl analogues [47]. Based on TRAP results on phenolic PPNs, the good antioxidant properties of caffeic, gallic, ferulic and sinapic acids (TRAP $=1.18-2.73 \mathrm{TE}$ ) were quite completely preserved in their PPNs analogues $\mathbf{4 b}, \mathbf{4 g}, \mathbf{4 h}$ and $\mathbf{4 i}$, respectively (TRAP $=1.44-2.22 \mathrm{TE}$ ), in correlation with the presence of a para-OH (Table 4). Regarding phenolic PPNs, our findings that (i) they all showed reactivity with AAPH-derived ROO•, and (ii) no spin adducts were detected upon reaction with $\mathrm{HOO} \cdot$ in aqueous medium (see above), we could conclude that these PPNs should act as classical antioxidants in oxidative stress situation. However one must consider that in buffers PPNs$\mathrm{OOH}$ nitroxides have relatively short half-lives [48] and that the addition rate of the bulky AAPHderived peroxyl radical at the hindered nitrone site of PPNs is likely too low to compete with H-atom abstraction.

Superoxide quenching activity. First, the xanthine oxidase inhibiting activity of PPNs and four parent phenolic acids was assessed using a reported procedure [49]. Each compound (ranging 1-100 $\mu \mathrm{M}$ ) was incubated at $37{ }^{\circ} \mathrm{C}$ for $30 \mathrm{~min}$ with a mixture of xanthine $(50 \mu \mathrm{M})$-xanthine oxidase $(1.25 \mathrm{mU} / \mathrm{mL})$ in DMSO (1\%)-supplemented PBS (200 mM, pH 7.5) and uric acid formation was monitored spectrophotometrically. Under these conditions, none of the tested compounds interfered with uric acid formation (not shown), whereas in this assay known xanthine oxidase inhibitors such as allopurinol and quercetin showed $\mathrm{IC}_{50}$ values of $0.95 \pm 0.07 \mu \mathrm{M}$ and $3.50 \pm 0.14 \mu \mathrm{M}$, respectively. Our results are in 
agreement with the reported weak activity of caffeic, gallic and sinapic acids (at concentrations up to $100 \mu \mathrm{M})$ toward xanthine oxidase [50].

Next, $\mathrm{O}_{2} \bullet^{-}$inhibition properties of the new compounds, selected phenolic acids and antioxidants Trolox and quercetin (within the range $0.1 \mu \mathrm{M}-40 \mathrm{mM}$ ) were evaluated at $25{ }^{\circ} \mathrm{C}$ in DMSO $(0.1 \%)$ supplemented glycine buffer $(6.25 \mathrm{mM}, \mathrm{pH} 10.1)$ by an improved method ${ }^{43}$ using allopurinol (12.5 $\left.\mu \mathrm{M}\right)$ xanthine oxidase $(0.458 \mathrm{mU} / \mathrm{mL})$ as the free radical generator and lucigenin chemiluminescence as the detector. Under basic conditions, $\mathrm{O}_{2}{ }^{--}$may undergo two competitive reactions in the presence of PPNs, i.e., (i) addition at the electrophilic carbon of the nitrone function (that is the spin trapping reaction) and/or (ii) electron transfer from the phenolate groups $[10,25,45]$, in the case of antioxidant-based PPNs. Consistent with the spin trapping mechanism, $\mathrm{IC}_{50}$ values $<60 \mu \mathrm{M}$ were obtained for non-phenolic PPNs $4 \mathbf{j}-\mathbf{p}$ and the most active within this set of nitrones were those bearing electron-withdrawing substituents at ortho or para position (Table 4). Indeed, such attractive inductive effects, which could accelerate the rate of $\mathrm{O}_{2} \cdot^{-}$addition by increasing the electrophilicity of the carbon of the nitrone group, may also explain the 10-fold lower activity found for PBN vs PPN, which bears an electronegative $\beta$ diethoxyphosphoryl group. Thus, both attractive effects of $(\mathrm{EtO})_{2} \mathrm{P}(\mathrm{O})$ moiety and aromatic substituents on $\mathrm{O}_{2}{ }^{-}$inhibition superimposed in nitrones $\mathbf{4} \mathbf{j}-\mathbf{p}$, leading to a 7-90 increase in activity vs PPN. Moreover, the $\beta$-phosphorylated secondary amine 7 (Figure 5, inset) showed no activity $\left(\mathrm{IC}_{50}>40 \mathrm{mM}\right.$ ) in the assay, further confirming that the nitrone function is an active site for scavenging. Finally, 2,6Me-PPN 4q exhibited a poor scavenging effect $\left(\mathrm{IC}_{50} \sim 350 \mu \mathrm{M}\right)$ as a possible consequence of the slow rate of radical addition at the sterically-hindered nitrone site (Figure 2B).

Of the phenolic PPNs 4a-i tested against $\mathrm{O}_{2} \cdot^{-}, 3,5-\mathrm{OH}-\mathrm{PPN}$ 4e was the less active, being however twice better than PPN (Table 4). Hydroxylated PPNs showing the best activities were substituted at the ortho or para position (e.g., in $\mathbf{4 a}, \mathbf{c}$ ) and, as in the DPPH assay above, compounds having a 3,4-OH pattern (i.e., 4d,g) exhibited antioxidant properties equivalent to their structural analogues (caffeic and gallic acids, respectively) and references (Trolox and quercetin). In contrast, 3-MeO substituted $4 \mathbf{i}$ was 
found less active than sinapic acid while $\mathbf{4 h}$ and ferulic acid demonstrated similar effects. It is noteworthy that at the basic $\mathrm{pH}$ of the assay hydroxylated PPNs predominate in the phenolate anionic form, a situation reported to favor $\mathrm{O}_{2}{ }^{-}$quenching by electron transfer [45]. However, this does not rule out that part of the inhibition effect seen here reflects actual $\mathrm{O}_{2} \cdot{ }^{--}$trapping at the nitrone site.

PPNs Cytotoxicity on A549 Cells and Lipophilicity. The cytotoxic properties of PPN, selected PPNs derivatives, four related phenolic acids, and PBN were screened against A549 human lung carcinoma cells by measuring lactate dehydrogenase (LDH) release and cell ATP content, and by running FMCA and MTT cell viability and metabolic activity assays (see details in Supporting Information). Cells were incubated in DMEM containing 0.5\% DMSO as vehicle for $1-48 \mathrm{~h}$ with nine PPNs that showed the highest overall antioxidant potency (Table 4) and/or NO-releasing property (Figure 4B) in comparison to less active nitrones such as $\mathbf{4 c}, 4 \mathbf{4}, 4 \mathbf{l}, \mathbf{4 n}$ and $4 \mathbf{0}$ at a range of concentrations relevant to general pharmacological usage (i.e., $10 \mu \mathrm{M}-1 \mathrm{mM}$ ) or compatible with EPR spin trapping (i.e., $10-30 \mathrm{mM}$ ). Prior to experiments we checked that addition of $0.5 \%$ DMSO in DMEM had no impact vs DMEM alone on LDH release, ATP content decrease and loss of viability of confluent cells after incubation for $48 \mathrm{~h}$ (not shown).

Using an incubation time of $6 \mathrm{~h}$ and concentrations up to $1 \mathrm{mM}$, none of the tested compounds demonstrated cytotoxicity, i.e., LDH leakage (overall range of $29 \pm 2.6-32.6 \pm 1.9 \mathrm{U} / \mathrm{L}$ in extracellular medium) did not exceed $2 \%$ of total LDH activity of untreated cells (being $1979 \pm 240 \mathrm{U} / \mathrm{L}$ ), while ATP content was not significantly altered (overall range of $4.93 \pm 0.25-6.12 \pm 0.19 \mu \mathrm{M}$ vs $5.69 \pm 0.41 \mu \mathrm{M}$ in control cells, $P>0.5$ by one-way ANOVA). Since FMCA and MTT assays showed a $95-99 \%$ preservation of cell viability following treatment with PPNs for $6 \mathrm{~h}$ (not shown), a common nontoxic concentration of $200 \mu \mathrm{M}$ was adopted in experiments on isolated rat aortic rings (see below).

Table 5 (left panel) summarizes $\mathrm{IC}_{50}$ values obtained upon incubating cells for $48 \mathrm{~h}$ with an extended concentration range of $0.01-30 \mathrm{mM}$. Gallic and caffeic acids decreased cell viability by $50 \%$ at concentrations as low as $\sim 370 \mu \mathrm{M}$ and $\sim 630 \mu \mathrm{M}$, respectively, while a ca. 8-10-fold lower cytotoxic 
effect was observed with the methoxylated ferulic and sinapic acids. Whereas this same trend was found among the PPNs derivatives $\mathbf{4 d}, \mathbf{g}-\mathbf{i}$ of these phenolic acids, the nitrones were found comparatively less cytotoxic, e.g., the mean $\mathrm{IC}_{50}$ was $\sim 14 \mathrm{mM}$ for $4 \mathbf{i}$ and only $\sim 5 \mathrm{mM}$ for sinapic acid. Of interest, the mean $\mathrm{IC}_{50}$ value for PBN ( $\left.\sim 9 \mathrm{mM}\right)$, close to those reported in bovine aortic endothelial cells $(9.4 \mathrm{mM})[51]$ or 3 T3 murine fibroblasts (7 mM) [52], slightly improved for PPN ( 13 mM) despite this latter nitrone was more lipophilic (see computed AlogP values in Table 4). In this regard, literature reported a connexion between cytotoxicity of phosphorylated nitrones and lipophilicity-driven cell penetration and/or disturbance of membrane integrity [51-54], a trend confirmed in this study for PPNs such as 4-CO $\mathrm{CO}_{2}$ PPN 4o, 2- $\mathrm{CF}_{3}-\mathrm{PPN}$ 4p or 2,6-Me-PPN 4q having AlogP values higher than that of PPN (i.e., 1.65). In marked contrast, the most hydrophilic antioxidant-based nitrones 3,4-OH-PPN 4d and 3,4,5-OH-PPN 4g, which demonstrated the best antioxidant potency (Table 4), were the most cytotoxic of the tested PPNs (Table 5, left panel). Consistent with data showing that methoxylation of polyhydroxyphenols results in decreased cytotoxicity [55], a significant increase in $\mathrm{IC}_{50}$ values was achieved by nitrones 4OH-3-OMe-PPN 4h and 4-OH-3,5-OMe-PPN 4i although they are more lipophilic than their non methoxylated analogues $\mathbf{4 d}, \mathbf{g}$, respectively. In terms of a possible mechanism underlying the cytotoxicity of the new antioxidant, phenolic-based PPNs, the detrimental prooxidant action of intermediately formed $\mathrm{ArO} \cdot$ radicals on intracellular pool and/or key signalling enzymes can be hypothesized, similar to that proposed for flavonoids [55]. Based upon this mechanism of action, studies are currently underway to examine the anti-proliferative and apoptotic properties of anticancer drugs constructed from phenolic antioxidants such as ferulic and caffeic acids [56]. Unrelated to its lipophilicity 2-NO $2-\mathrm{PPN} \mathbf{4 j}$ was found 6-fold more cytotoxic than PPN, a result not surprising given the known toxicity of nitroso spin traps [51] and nitroaromatic compounds.

When cells were exposed to PPNs for $48 \mathrm{~h}$ the mean $\mathrm{IC}_{50}$ values found for each tested compound using FMCA, ATP and MTT assays showed little dispersion, suggesting the cytotoxicity seen here is mainly due to alteration of intracellular enzymatic and mitochondrial functions that caused cell death. In parallel, however, only a modest LDH leakage was observed for all PPNs (5-25\% of total baseline 
intracellular content) as concentrations causing cell death were applied. Under these conditions the calculated $\mathrm{IC}_{50}$ values for the $\mathrm{LDH}$ assay are overestimated, showing an apparent increase of viability as compared to the above assays, giving false-positive results. It is thus possible that PPNs-induced membrane damage and/or necrosis is low compared to intracellular alterations or, more likely, that released LDH was degraded after $48 \mathrm{~h}$ incubation to reach undetectable levels.

In the last step of the cytotoxicity study, we looked for concentration and incubation conditions allowing PPNs to be safely used for EPR-spin trapping studies in stressed cells. When A549 cells were exposed for $3 \mathrm{~h}$ to $15 \mathrm{mM}$ of various nitrones, the MTT assay showed no significant decrease in cell viability compared to untreated cells (overall range of $97.1 \pm 1.2-101.3 \pm 1.9 \%, P>0.5$ by one-way ANOVA). However, a few nitrones led to a decrease of total intracellular LDH indicating they significantly impact cell integrity (i.e., when $\Delta>20 \%$; Table 5), particularly the antioxidant 3,4-OHPPN 4d and 3,4,5-OH-PPN 4g, and even more the nitro derivatives $\mathbf{4 j}$, $\mathbf{l}$. When a short incubation time was applied, LDH leakage therefore appeared as a good endpoint of early cytotoxicity of PPNs. Using this index, we found a minimal cytotoxicity (i.e., $\Delta<5 \%$ ) for all tested PPNs when incubation time was $1 \mathrm{~h}$ and, according to these data, the safe use of PPNs at $15 \mathrm{mM}$ as EPR probes in cell cultures or aortic rings preparations (see below) was considered guaranteed for incubation durations of $\sim 20 \mathrm{~min}$.

\section{NO-Mediated Vasorelaxant Potency and Antioxidant Properties of PPNs in Aortic Ring}

Preparations. To investigate the vascular relaxant potency of a subset of PPNs, we used endotheliumintact rat aortic rings precontracted with $5 \times 10^{-6} \mathrm{M}$ of the $\alpha 1$-adrenoceptor agonist phenylephrine (PE) to similar levels. Concentration-response curves to endothelium-independent NO-donor SNP were recorded in the presence of nitrones $(200 \mu \mathrm{M})$ in $\mathrm{KH}$ buffer with $0.1 \%$ DMSO as cosolvent, allowing quantification of the potency half maximal effective concentration $\left(\mathrm{pEC}_{50}\right)$ and relaxation efficacy $\left(R_{\max }\right)$

Most of the examined compounds improved concentration-dependent vasorelaxing responses to SNP, with full efficacy as shown by $R_{\max }$ values $\sim 100 \%$. Consistent with the implication of NO in the 
observed vasorelaxing effect, the strongest in vitro NO-donating PPNs 4j,p,q (see Figure 4B) significantly enhanced the potency of vasorelaxation to SNP (Table 5). However, the vasorelaxing actions of weaker, yet efficient NO donors such as $\mathbf{4 a}, \mathbf{b}$ were almost comparable to that of PBN, despite it releases $\sim 6$-times less NO amounts in vitro (Figure 4B). High concentrations of PBN (millimolar range) were needed to induce a sustained dose-response relaxation in rat pulmonary arteries contracted with PE [57]. Here, a number of PPNs tested at submillimolar doses (i.e., having $\mathrm{pEC}_{50}>8.6$ ), but not PBN, demonstrated their remarkable ability to induce a leftward shift of the relaxation curve to SNP although it is a far better NO-donor than the nitrones (by at least five orders of magnitude).

Besides their NO-donating effect, PPNs are endowed with other intrinsic properties that may also induce strong vasorelaxation of rings, a feature which could explain the apparent lack of correlation between the ease of NO donation and the vasodilation potency. To illustrate, we found that 3,4-OH-PPN 4d and 3,4,5-OH-PPN $4 \mathbf{g}$ significantly improved the relaxant response to SNP by $20 \%$ although both PPNs are weak NO-donors in vitro (Table 5). To assess if this effect could rely on the decrease of vascular basal $\mathrm{O}_{2}{ }^{-}$, the response to SNP was determined in six additional wells in which SOD (30 $\mathrm{U} / \mathrm{mL}$ ) was preincubated into the ring medium for $30 \mathrm{~min}$ before adding PE. A significant increase of $\mathrm{pEC}_{50}$ value $(9.05 \pm 0.03, P<0.05$ vs vehicle $)$ with full efficacy $\left(R_{\max }=105 \%\right)$ was observed in these rings. Accordingly, improvement in the vasorelaxant effect seen for the antioxidant PPNs 4d,g may be an indirect consequence of their good $\mathrm{O}_{2} \cdot^{-}$scavenging properties (Table 4) which preserves endothelium-derived NO biodisponibility. This second chemical mechanism by which PPNs may improve vasorelaxant response to SNP agrees with previous observations in vessels treated with polyphenolic compounds such as quercetin, which strongly enhanced vasodilatation in an endotheliumindependent manner [58,59].

A third mechanism underlying PPNs vasorelaxant properties can be postulated from the finding that the $\mathrm{pEC}_{50}$ data of the methoxylated $\mathbf{4 h}, \mathbf{i}$ were similar to that of hydroxylated $\mathbf{4 d , g}$ (Table 5) despite they are $\sim 100$-times less efficient $\mathrm{O}_{2}{ }^{-}$scavengers (Table 4) and show very weak NO-donating potency 
(Figure 4B). Indeed, the key structural feature of derivatives $\mathbf{4 h , \mathbf { i }}$ is a 3-methoxyphenyl group, whose presence in the ferulic and sinapic acids structures was reported to confer improved relaxant activity as compared to caffeic acid in rat aortic rings [60]. In this connection, a bioactive effect involving inhibition of endothelial NADPH oxidase ROS formation was demonstrated for a wide series of 3methoxyphenyl substituted flavonoids and phenolics [61].

On this basis of preserving the endothelium-mediated NO release function under high levels of ROS, we speculated that the lead antioxidant-based PPNs emerging from Table 4 should demonstrate enhanced efficacy. In additional experiments, aortic rings were first incubated for 10 min with a xanthine $(0.1 \mathrm{mM})$-xanthine oxidase $(10 \mathrm{mU} / \mathrm{mL}) \mathrm{O}_{2}{ }^{-}$generator, then precontracted with $\mathrm{PE}\left(\sim 10^{-6} \mathrm{M}\right)$ in the presence of either nitrones $\mathbf{4 d}, \mathbf{g}-\mathbf{i}$, PBN or PPN (all at $200 \mu \mathrm{M}$ ) and the relaxing activity to the endothelium-dependent vasorelaxant agent acetylcholine ( $\left.\mathrm{ACh} ; 10^{-9}-10^{-4} \mathrm{M}\right)$ was examined. Addition of $\mathrm{O}_{2}{ }^{-}$led to significant endothelial dysfunction ( $\sim 40 \%$ reduction in $R_{\max }$ to $\mathrm{ACh}$ ), which was almost completely reversed by all tested PPNs, but only to a lesser extent by PBN or PPN (Table 6). Compounds 4d,g, which showed the best $\mathrm{O}_{2}{ }^{-}$scavenging properties (Table 4) and had moderate NO releasing properties (Figure 4B), were the most efficient in limiting $\mathrm{O}_{2}{ }^{-}$-induced rightward shift of the concentration-response curves to ACh (Figure 6A), which result to the decrease of $\mathrm{pEC}_{50}$ (Table 6).

Since these latter data strongly implicate the antioxidant properties of PPNs in protecting endothelial function upon exogenous ROS formation, we carried out a last series of experiments in aortic rings to assess biochemical changes following stimulation of vascular NADPH oxidase to produce high levels of $\mathrm{O}_{2}{ }^{-}$. Rings were incubated for 90 min with excess NADPH $(1 \mathrm{mM})$ and the protective effect of eight PPNs $(200 \mu \mathrm{M})$ on protein oxidation was evaluated by assaying tissue protein carbonyl levels with an improved procedure [62]. Incubation medium contained diethyldithiocarbamate (DTC; $15 \mu \mathrm{M})$ to inactivate intracellular SOD [63]. Addition of NADPH to the incubation medium resulted in a burst of protein carbonyls, which was expectedly reversed by the NADPH oxidase inhibitor diphenylene iodonium (DPI). Treatment with PPNs, but not PBN, achieved a variable, significant inhibition of ROS- 
induced elevation of protein oxidation (Figure 6B), with the four antioxidant-based compounds $\mathbf{4 d , g}-\mathbf{i}$ having a better efficacy than nitrones $\mathbf{4 b}, \mathbf{e}, \mathbf{q}$ which have shown a poorer global antioxidant effect in vitro (Table 4). However, this correlation between antioxidant effects and apparent limitation of lipid peroxidation of rings was not observed for 4-OH-PPN $\mathbf{4 c}$ which significantly inhibited protein carbonyls formation despite its moderate TRAP value and lack of reactivity toward DPPH. Some slight discrepancy in the inhibition results could also be seen between the methoxyphenyl-substituted compounds $\mathbf{4 h , i}$ and the strong antioxidant polyhydroxylated derivatives 4d,g (Figure 6B), suggesting other factors may be involved in the in vivo effects of nitrones, such as lipophilicity or cell permeation. Other mechanisms such as reversion of eNOS dysfunction have been proposed to explain the protection of endothelial integrity by nitrones [include new 64 and 65]. On the other hand, hydrolysis products of PPNs such as benzaldehydes and hydroxylamine 5 (Figure 5) may exert stronger antioxidant effects. This has been reported for $N$-tert-butylhydroxylamine which displays powerful $\mathrm{O}_{2} \bullet^{-}$inhibition at mitochondrial level and is considered the major active species mediating the anti-senescence action of PBN [64 (will be 66)].

Spin Trapping in Aortic Rings Undergoing Oxidative Stress. With the protein carbonyls data in hand, we sought (i) to validate PPNs as efficient in vivo EPR probes by characterizing free radical species released in the incubation medium of rings preparations exposed to NADPH $(1 \mathrm{mM})$ as described above, and (ii) to test if EPR signal intensities may bear witness to the antioxidant role of nitrones as shown in Figure 6B.

After having stimulated the rings for $60 \mathrm{~min}$ with NADPH $(1 \mathrm{mM})$ in the presence of antioxidant PPNs $(200 \mu \mathrm{M})$ as described above, the incubation medium was renewed with a mixture of NADPH (1 $\mathrm{mM})$ and each PPNs (15 mM) in buffer containing 1\% DMSO as cosolvent, incubation was prolonged for $20 \mathrm{~min}$ at $37^{\circ} \mathrm{C}$ and samples were assayed by EPR at room temperature following a freeze/thawing sequence. For PPNs $\mathbf{4 b}-\mathbf{e}$ and $\mathbf{4 g}-\mathbf{i}$, with the exception of PBN, easily detectable EPR spectra characteristic of PPNs- $\mathrm{CH}_{3}$ adducts (Table 2) were obtained in the rings supernatants, the signal being 
abolished when either DMSO or NADPH are omitted, or upon addition of DPI to the complete incubation system (Figure 7A). In most experiments, computer simulation of the EPR signals revealed decomposition adducts representing $<10 \%$ of the total signal. Our NADPH/NADPH oxidase inhibition data strongly suggest that trapped methyl radicals seen here are formed secondary to $\mathrm{O}_{2} \cdot^{-}$which gives almost undetectable PPNs spin adducts in buffers. Moreover, the fact that DMSO was required to obtain the PPNs-Me signals indicates $\mathrm{HO} \cdot$ radicals were formed (see EPR section). Indeed a DMSO-assisted spin trapping involving linear nitrones such as PBN has been shown a useful technique to specifically evidence hydroxyl radical production in vivo [65].

Upon NADPH stimulation of rings, high levels of $\mathrm{O}_{2}{ }^{-}$and/or $\mathrm{H}_{2} \mathrm{O}_{2}$ are generated by membrane located endothelial and vascular NAPDH oxidases [66], consecutively leading to HO formation [67]. In our indirect radical-trapping system, we expected to get lower EPR signals for nitrones having at least two available sites for $\mathrm{HO} \cdot$ addition, i.e., for antioxidant PPNs. Figure 7B reveals that the mean PPNs$\mathrm{CH}_{3}$ EPR signal intensities show apparent inverse correlation with antioxidant properties of Table 4 and with protein carbonyl contents of Figure 6B. Finally, to account for the reliability of PPNs adduct concentrations of freeze/thawed samples, we recorded the decay of EPR signal intensities of chemically formed PPNs- $\mathrm{CH}_{3}$ adducts after 4 days of storage in liquid nitrogen. While the concentrations of thawed methyl radical adducts of PBN and PPN decayed upon by $25 \%$ and $30 \%$, respectively, they decreased by only $<5 \%$ for the other tested PPNs (not shown). Regardless of the comparative kinetics of the reactions

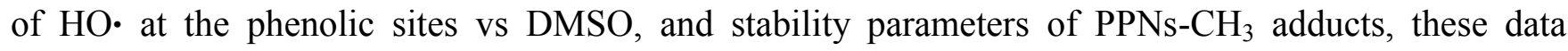
highlight the behavior of phenolic acids-based PPNs 4d,g-i as dual antioxidants and EPR probes, which should be preferred to PBN or PPN which may yield underestimated quantitative results on ROS formation in vivo.

\section{Conclusions}


In summary, we have documented the versatile synthesis of PPNs, a series of new diethoxyphosphoryl substituted derivatives of $\alpha$-phenyl- $N$-tert-butyl nitrone having a variably substituted aromatic ring, constructed on a natural phenolic antioxidant scaffold or which brings about steric constraint. These PPNs were subjected to a complete panel of in vitro (EPR spin trapping, antioxidant assays and NOdonating properties) and in vivo (cytotoxicity, vasorelaxant effect and protection against ROS-induced vascular protein oxidation) testing. Lead hybrid PPNs $\mathbf{4 d}$ and $\mathbf{4 g - i}$ bearing an aromatic structure close to that of caffeic, gallic, ferulic and sinapic acids emerged as non-toxic, moderately-lipophilic potential alternatives to PBN in pharmacological studies relevant to vascular tone control.

\section{Experimental Section}

Chemistry. General Methods. Starting materials, reagents and solvents were from Sigma-Aldrich (Saint Quentin Fallavier, France), Fluka, SDS and Acros Organics (Fisher Scientific, Illkirch, France) and were of analytical grade quality. ${ }^{1} \mathrm{H}$ and ${ }^{13} \mathrm{C}$ NMR spectra were recorded on a Bruker DPX-300 (at $300 \mathrm{MHz}$ ) or Bruker Avance III nanobay-400 (at $400 \mathrm{MHz}$ ) spectrometers in $\mathrm{CDCl}_{3}$ or DMSO- $d_{6}$ solution (from Euriso-Top, Saint Aubin, France). Chemical shifts $(\delta)$ for ${ }^{1} \mathrm{H}$ and ${ }^{13} \mathrm{C}$ are reported in parts per million (ppm) relative to tetramethylsilane (TMS) as internal standard and coupling constants $(J)$ are given in Hertz (Hz). Multiplicity abbreviations used are as follows: br, broad; s, singlet; d, doublet; dd, doublet of doublets; $\mathrm{t}$, triplet; dt, doublet of triplets; td, triplet of doublets; m, multiplet. Melting points were obtained using a Büchi Melting Point B-540 apparatus and are not corrected. High-resolution mass spectrometry (HRMS) in electron spray ionization (ESI) was performed at the Spectropole (Analytical Laboratory) at Campus St. Jérôme (Marseille, France) on a Q-STAR Elite instrument (Applied Biosystems, USA). Purity of final compounds was determined at $254 \mathrm{~nm}$ by HPLC (Agilent 1200 series, USA) using a C18 column (Beckman Coulter Inc., USA) and was 95\% or greater.

Synthesis of diethyl-2-aminopropan-2-ylphosphonate (1). Being a starting material in all syntheses, this compound was prepared in large scale. Acetone $(220 \mathrm{~mL}, 3 \mathrm{~mol}, 2 \mathrm{eq})$ was bubbled in continuum 
with dry ammonia at $5^{\circ} \mathrm{C}$ for $15 \mathrm{~min}$. Diethylphosphite $(192 \mathrm{~mL} 1.5 \mathrm{~mol})$ was added dropwise and the solution was stirred at $5{ }^{\circ} \mathrm{C}$ for $2 \mathrm{~h}$. After removing the ammonia-bubbling, the mixture was stirred at room temperature overnight. The excess acetone was evaporated under reduced pressure and the residue was treated with $20 \%$ aqueous $\mathrm{NaOH}(20 \mathrm{~mL})$ and chloroform $(100 \mathrm{~mL})$. The organic layer was separated, dried over $\mathrm{MgSO}_{4}$ and filtered. The solvent was removed under reduced pressure to give $\mathbf{1}$ as a colourless oil $(438 \mathrm{~g}, 75 \%):{ }^{1} \mathrm{H}$ NMR $\left(300 \mathrm{MHz}, \mathrm{CDCl}_{3}\right) \delta 4.12-4.01\left(\mathrm{~m}, 4 \mathrm{H}, 2 \times \mathrm{OCH}_{2} \mathrm{CH}_{3}\right)$, $1.30-1.16(\mathrm{~m}, 12 \mathrm{H}) ;{ }^{13} \mathrm{C} \mathrm{NMR}\left(75 \mathrm{MHz}, \mathrm{CDCl}_{3}\right) \delta 62.3\left(\mathrm{OCH}_{2} \mathrm{CH}_{3}\right), 62.2\left(\mathrm{OCH}_{2} \mathrm{CH}_{3}\right), 49.0(\mathrm{~d}, J=$ $\left.147.7 \mathrm{~Hz}, \mathrm{C}\left(\mathrm{CH}_{3}\right)_{2}\right), 25.1\left(\mathrm{~d}, J=3.8 \mathrm{~Hz}, \mathrm{C}\left(\mathrm{CH}_{3}\right)_{2}\right), 16.6\left(\mathrm{OCH}_{2} \mathrm{CH}_{3}\right), 16.5\left(\mathrm{OCH}_{2} \mathrm{CH}_{3}\right) ;{ }^{31} \mathrm{P}$ NMR $(121$ $\left.\mathrm{MHz}, \mathrm{CDCl}_{3}\right) \delta 32.39$.

Synthesis of diethyl-2-nitropropan-2-ylphosphonate (2). To a vigorously stirred mixture of 1 (20 g, $0.1 \mathrm{~mol})$ and $\mathrm{MgSO}_{4}(24 \mathrm{~g}, 0.2 \mathrm{~mol}, 2 \mathrm{eq})$ in acetone/water $(150: 20 \mathrm{~mL})$ and water $(20 \mathrm{~mL})$ was added $\mathrm{KMnO}_{4}(32 \mathrm{~g}, 0.2 \mathrm{~mol}, 2 \mathrm{eq})$ portionwise. The mixture was heated at $50-55^{\circ} \mathrm{C}$ for $1 \mathrm{day}$, cooled at room temperature and filtered. The cake was washed with $\mathrm{Et}_{2} \mathrm{O}$, the filtrate was concentrated and the residue was extracted with $\mathrm{CH}_{2} \mathrm{Cl}_{2}(3 \times 50 \mathrm{~mL})$. The organic layers were gathered, dried over $\mathrm{MgSO}_{4}$, filtered and concentrated to yield 2 as a pale yellow oil (16 g, 70\%): ${ }^{1} \mathrm{H}$ NMR $\left(300 \mathrm{MHz}, \mathrm{CDCl}_{3}\right) \delta 4.11(\mathrm{~m}, 4 \mathrm{H}$, $\left.2 \times \mathrm{OCH}_{2} \mathrm{CH}_{3}\right), 1.72\left(\mathrm{~d}, J=14.5 \mathrm{~Hz}, 6 \mathrm{H}, \mathrm{C}\left(\mathrm{CH}_{3}\right)_{2}\right), 1.24\left(\mathrm{t}, J=7.1 \mathrm{~Hz}, 6 \mathrm{H}, 2 \times \mathrm{OCH}_{2} \mathrm{CH}_{3}\right) ;{ }^{13} \mathrm{C} \mathrm{NMR}$ $\left(75 \mathrm{MHz}, \mathrm{CDCl}_{3}\right) \delta 86.0\left(\mathrm{~d}, J=151.30 \mathrm{~Hz}, C\left(\mathrm{CH}_{3}\right)_{2}\right), 64.0\left(\mathrm{~d}, J=7.1 \mathrm{~Hz}, \mathrm{OCH}_{2} \mathrm{CH}_{3}\right), 22.6(\mathrm{~d}, J=1.0$ $\left.\mathrm{Hz}, \mathrm{C}\left(\mathrm{CH}_{3}\right)_{2}\right), 16.0\left(\mathrm{~d}, J=6.0 \mathrm{~Hz} \mathrm{OCH}_{2} \mathrm{CH}_{3}\right) ;{ }^{31} \mathrm{P} \mathrm{NMR}\left(121 \mathrm{MHz}, \mathrm{CDCl}_{3}\right) \delta 17.24$.

Synthesis of diethyl-2-(hydroxyamino)propan-2-ylphosphonate (3). Compound 2 (4.0 g, 18 mmol, $1.7 \mathrm{eq})$ and $\mathrm{NH}_{4} \mathrm{Cl}(0.58 \mathrm{~g}, 10.8 \mathrm{mmol})$ were dissolved in water $(20 \mathrm{~mL})$ at room temperature under vigorous stirring. The mixture was cooled at $-10{ }^{\circ} \mathrm{C}$ and $\mathrm{Zn}$ powder $(2.4 \mathrm{~g}, 37 \mathrm{mmol}, 3.4 \mathrm{eq})$ was added portionwise. The mixture was stirred at room temperature for $2 \mathrm{~h}$ and at $50-55{ }^{\circ} \mathrm{C}$ for $1 \mathrm{~h}$, cooled to room temperature and filtered. The filtrate was extracted with $\mathrm{CH}_{2} \mathrm{Cl}_{2}(3 \times 20 \mathrm{~mL})$, the organic layers were gathered, dried over $\mathrm{MgSO}_{4}$, filtered and concentrated under vacuum. The residue was precipitated in hexane $(20 \mathrm{~mL})$ to yield 3 as colourless crystals $(1.2 \mathrm{~g}, 53 \%), \mathrm{mp} 62.3{ }^{\circ} \mathrm{C}$ (litt. [68] $\left.56-57{ }^{\circ} \mathrm{C}\right):{ }^{1} \mathrm{H}$ $\operatorname{NMR}\left(300 \mathrm{MHz}, \mathrm{CDCl}_{3}\right) \delta 3.93\left(\mathrm{~m}, 4 \mathrm{H}, 2 \times \mathrm{OCH}_{2} \mathrm{CH}_{3}\right), 1.11\left(\mathrm{~d}, J=15.4 \mathrm{~Hz}, 6 \mathrm{H}, \mathrm{C}\left(\mathrm{CH}_{3}\right)_{2}\right), 1.10(\mathrm{t}, J=$ 
$\left.7.2 \mathrm{~Hz}, 6 \mathrm{H}, 2 \times \mathrm{OCH}_{2} \mathrm{CH}_{3}\right) ;{ }^{13} \mathrm{C} \mathrm{NMR}\left(75 \mathrm{MHz}, \mathrm{CDCl}_{3}\right) \delta 61.6\left(\mathrm{~d}, J=7.1 \mathrm{~Hz}, \mathrm{OCH}_{2} \mathrm{CH}_{3}\right), 57.6(\mathrm{~d}, J=$ $\left.146.4 \mathrm{~Hz}, C\left(\mathrm{CH}_{3}\right)_{2}\right), 20.0\left(\mathrm{~d}, J=1.6 \mathrm{~Hz}, \mathrm{C}\left(\mathrm{CH}_{3}\right)_{2}\right), 16.0\left(\mathrm{~d}, J=6.0 \mathrm{~Hz}, \mathrm{OCH}_{2} \mathrm{CH}_{3}\right) ;{ }^{31} \mathrm{P} \mathrm{NMR}(121$ $\left.\mathrm{MHz}, \mathrm{CDCl}_{3}\right) \delta: 30.69$

General procedure for the synthesis of PPNs (4a-4r). A mixture of 3 (4 mmol, 1 eq) and the corresponding benzaldehyde ( $4 \mathrm{mmol}, 1 \mathrm{eq})$ in THF or DCE $(30 \mathrm{~mL})$ was stirred at $100{ }^{\circ} \mathrm{C}$ for $4 \mathrm{~h}$ in the presence of $\mathrm{MgSO}_{4}$ (spatula tip). The mixture was allowed to cool at room temperature and filtered. The filtrate was concentrated under vacuum and the residue was purified by either precipitation or crystallization from a defined solvent.

2-(Diethoxyphosphoryl)-N-(benzylidene)propan-2-amine oxide (PPN). The title compound was obtained from 3 (400 mg, $1.9 \mathrm{mmol})$ and benzaldehyde (200 mg, $1.9 \mathrm{mmol})$ in THF (20 mL) as a yellow pale oil after $\mathrm{SiO}_{2}$-chromatography $\left(\mathrm{CHCl}_{3} / \mathrm{CH}_{3} \mathrm{CN}, 50: 50\right)(65 \mathrm{mg}, 12 \%):{ }^{1} \mathrm{H} \mathrm{NMR}\left(400 \mathrm{MHz}, \mathrm{CDCl}_{3}\right)$ $\delta 8.20(\mathrm{dt}, J=7.5$ and $J=1.8 \mathrm{~Hz}, 2 \mathrm{H}, \mathrm{H}-2), 7.68(\mathrm{~d}, J=2.7 \mathrm{~Hz}, 1 \mathrm{H}, \mathrm{HC}=\mathrm{NO}), 7.34(\mathrm{~d}, J=7.5 \mathrm{~Hz}, 2 \mathrm{H}$, H-3), 7.33 (br d, 1H, H-4), $4.13\left(\mathrm{~m}, 4 \mathrm{H}, 2 \times \mathrm{OCH}_{2} \mathrm{CH}_{3}\right), 1.79\left(\mathrm{~s}, 3 \mathrm{H}, \mathrm{C}\left(\mathrm{CH}_{3}\right)_{2}\right), 1.74(\mathrm{~s}, 3 \mathrm{H}$, $\left.\mathrm{C}\left(\mathrm{CH}_{3}\right)_{2}\right), 1.25\left(\mathrm{t}, J=7.0 \mathrm{~Hz}, 6 \mathrm{H}, 2 \times \mathrm{OCH}_{2} \mathrm{CH}_{3}\right) ;{ }^{13} \mathrm{C} \mathrm{NMR}\left(75 \mathrm{MHz}, \mathrm{CDCl}_{3}\right) \delta 133.2(\mathrm{~d}, J=2.0 \mathrm{~Hz}$, $\mathrm{HC}=\mathrm{NO}), 130.7(\mathrm{~d}, J=1.6 \mathrm{~Hz}, \mathrm{C}-1), 130.4(\mathrm{C}-4), 129.0(\mathrm{C}-3), 128.4(\mathrm{C}-2), 72.8(\mathrm{~d}, J=154.6$, $\left.C\left(\mathrm{CH}_{3}\right)_{2}\right), 63.4\left(\mathrm{~d}, J=7.2 \mathrm{~Hz}, \mathrm{OCH}_{2} \mathrm{CH}_{3}\right), 23.3\left(\mathrm{C}\left(\mathrm{CH}_{3}\right)_{2}\right), 16.4\left(\mathrm{~d}, J=6.1 \mathrm{~Hz}, \mathrm{OCH}_{2} \mathrm{CH}_{3}\right) ;{ }^{31} \mathrm{P}$ NMR $\left(162 \mathrm{MHz}, \mathrm{CDCl}_{3}\right) \delta$ 22.65. HRMS-ESI: calcd for $\mathrm{C}_{14} \mathrm{H}_{23} \mathrm{NO}_{4} \mathrm{P}^{+}[\mathrm{M}+\mathrm{H}]^{+}$300.1359, found 300.1360.

2-(Diethoxyphosphoryl)-N-(2-hydroxybenzylidene) propan-2-amine oxide $(2-O H-P P N ; 4 a)$. The title compound was obtained from $3(400 \mathrm{mg}, 2.0 \mathrm{mmol})$ and 2-hydroxybenzaldehyde $(230 \mathrm{mg}, 2.0 \mathrm{mmol})$ in DCE $(12.5 \mathrm{~mL})$ as a yellow oil $(0.3 \mathrm{~g}, 50 \%):{ }^{1} \mathrm{H}$ NMR $\left(300 \mathrm{MHz}, \mathrm{CDCl}_{3}\right) \delta 7.90(\mathrm{~d}, J=2.8 \mathrm{~Hz}, 1 \mathrm{H}$, $\mathrm{HC}=\mathrm{NO}), 7.39(\mathrm{td}, J=8.0$ and $J=1.5 \mathrm{~Hz}, 1 \mathrm{H}, \mathrm{H}-4), 7.15(\mathrm{dd}, J=7.9$ and $J=1.5 \mathrm{~Hz}, 1 \mathrm{H}, \mathrm{H}-6), 6.96$ (br d, $J=8.0 \mathrm{~Hz}, 1 \mathrm{H}, \mathrm{H}-3), 6.86$ (br t, $J=8.0 \mathrm{~Hz}, 1 \mathrm{H}, \mathrm{H}-5), 4.23\left(\mathrm{~m}, 4 \mathrm{H}, 2 \times \mathrm{OCH}_{2} \mathrm{CH}_{3}\right), 1.88(\mathrm{~s}, 3 \mathrm{H}$, $\left.\mathrm{C}\left(\mathrm{CH}_{3}\right)_{2}\right), 1.83\left(\mathrm{~s}, 3 \mathrm{H}, \mathrm{C}\left(\mathrm{CH}_{3}\right)_{2}\right), 1.35\left(\mathrm{t}, J=7.1 \mathrm{~Hz}, 6 \mathrm{H}, 2 \times \mathrm{OCH}_{2} \mathrm{CH}_{3}\right) ;{ }^{13} \mathrm{C} \mathrm{NMR}\left(75 \mathrm{MHz}, \mathrm{CDCl}_{3}\right) \delta$ 159.7 (C-2), 140.4 (d, $J=6.0$ Hz, HC=NO), 134.0 (C-6), 132.5 (C-4), 120.2 (C-5), 119.0 (C-3), 116.8

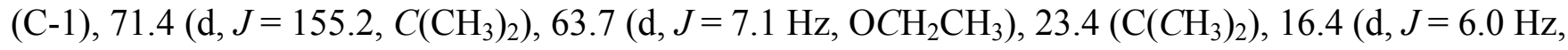


$\left.\mathrm{OCH}_{2} \mathrm{CH}_{3}\right) ;{ }^{31} \mathrm{P}$ NMR (121 MHz, $\left.\mathrm{CDCl}_{3}\right) \delta$ 21.91. HRMS-ESI: calcd for $\mathrm{C}_{14} \mathrm{H}_{23} \mathrm{NO}_{5} \mathrm{P}^{+}[\mathrm{M}+\mathrm{H}]^{+}$ 316.1308, found 316.1308.

2-(Diethoxyphosphoryl)-N-(3-hydroxybenzylidene)propan-2-amine oxide (3-OH-PPN; 4b). The title compound was obtained from 3 (500 mg, $2.4 \mathrm{mmol})$ and 3-hydroxybenzaldehyde (290 $\mathrm{mg}, 2.4 \mathrm{mmol})$ in DCE $(15 \mathrm{~mL})$ as pink crystals from a mixture $\mathrm{Et}_{2} \mathrm{O} / n$-hexane, 50:50 (0.33 g, 44\%), mp $101.2{ }^{\circ} \mathrm{C}:{ }^{1} \mathrm{H}$ NMR (400 MHz, $\left.\mathrm{CDCl}_{3}\right) \delta 8.36$ (br s, $\left.1 \mathrm{H}, \mathrm{H}-2\right), 7.74$ (d, $\left.J=2.8 \mathrm{~Hz}, 1 \mathrm{H}, H \mathrm{C}=\mathrm{NO}\right), 7.31$ (br d, $J=8.0$ $\mathrm{Hz}, 1 \mathrm{H}, \mathrm{H}-6), 7.19$ (t, $J=8.0 \mathrm{~Hz}, 1 \mathrm{H}, \mathrm{H}-5), 6.91(\mathrm{dd}, J=8.0$ and $J=2.1 \mathrm{~Hz}, 1 \mathrm{H}, \mathrm{H}-4), 4.23(\mathrm{~m}, 4 \mathrm{H}, 2 \times$ $\left.\mathrm{OCH}_{2} \mathrm{CH}_{3}\right), 1.87\left(\mathrm{~s}, 3 \mathrm{H}, \mathrm{C}\left(\mathrm{CH}_{3}\right)_{2}\right), 1.82\left(\mathrm{~s}, 3 \mathrm{H}, \mathrm{C}\left(\mathrm{CH}_{3}\right)_{2}\right), 1.33\left(\mathrm{t}, J=7.2 \mathrm{~Hz}, 6 \mathrm{H}, 2 \times \mathrm{OCH}_{2} \mathrm{CH}_{3}\right) ;{ }^{13} \mathrm{C}$ $\operatorname{NMR}\left(75 \mathrm{MHz}, \mathrm{CDCl}_{3}\right) \delta 157.1(\mathrm{C}-3), 135.5(\mathrm{~d}, J=6.0 \mathrm{~Hz}, \mathrm{HC}=\mathrm{NO}), 131.0(\mathrm{~d}, J=1.7 \mathrm{~Hz}, \mathrm{C}-1), 129.3$ (C-5), $121.7(\mathrm{C}-6), 118.7(\mathrm{C}-2), 115.6(\mathrm{C}-4), 72.7\left(\mathrm{~d}, J=155.2, C\left(\mathrm{CH}_{3}\right)_{2}\right), 63.7(\mathrm{~d}, J=7.2 \mathrm{~Hz}$

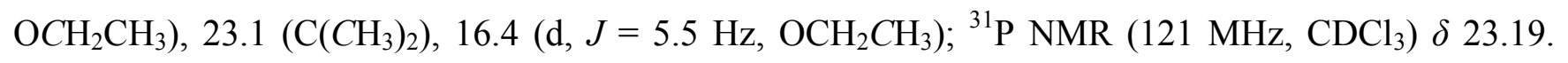
HRMS-ESI: calcd for $\mathrm{C}_{14} \mathrm{H}_{23} \mathrm{NO}_{5} \mathrm{P}^{+}[\mathrm{M}+\mathrm{H}]^{+} 316.1308$, found 316.1307 .

2-(Diethoxyphosphoryl)-N-(4-hydroxybenzylidene)propan-2-amine oxide (4-OH-PPN; 4c). The title compound was obtained from 3 (600 mg, $2.85 \mathrm{mmol})$ and 4-hydroxybenzaldehyde (350 mg, $2.85 \mathrm{mmol})$ in THF $(20 \mathrm{~mL})$ as colourless crystals from $\mathrm{Et}_{2} \mathrm{O}(0.63 \mathrm{~g}, 70 \%), \mathrm{mp} 138.9{ }^{\circ} \mathrm{C}$ (litt. [32] 138.5-139.5 $\left.{ }^{\circ} \mathrm{C}\right):{ }^{1} \mathrm{H} \mathrm{NMR}\left(300 \mathrm{MHz}, \mathrm{CDCl}_{3}\right) \delta 9.41($ br s, $1 \mathrm{H}, \mathrm{OH}), 7.88(\mathrm{~d}, J=8.6 \mathrm{~Hz}, 2 \mathrm{H}, \mathrm{H}-2), 7.37$ (br s, $1 \mathrm{H}$, $H \mathrm{C}=\mathrm{NO}), 6.75(\mathrm{~d}, J=8.6 \mathrm{~Hz}, 2 \mathrm{H}, \mathrm{H}-3), 4.27\left(\mathrm{~m}, 4 \mathrm{H}, 2 \times \mathrm{OCH}_{2} \mathrm{CH}_{3}\right), 1.84\left(\mathrm{~s}, 3 \mathrm{H}, \mathrm{C}(\mathrm{CH})_{2}\right), 1.79(\mathrm{~s}$, $\left.3 \mathrm{H}, \mathrm{C}\left(\mathrm{CH}_{3}\right)_{2}\right), 1.37\left(\mathrm{t}, J=7.1 \mathrm{~Hz}, 6 \mathrm{H}, 2 \times \mathrm{OCH}_{2} \mathrm{CH}_{3}\right) ;{ }^{13} \mathrm{C} \mathrm{NMR}\left(75 \mathrm{MHz}, \mathrm{CDCl}_{3}\right) \delta 159.8(\mathrm{C}-4), 133.4$ $(\mathrm{d}, J=6.6 \mathrm{~Hz}, \mathrm{HC}=\mathrm{NO}), 131.4(\mathrm{C}-2), 121,8(\mathrm{~d}, J=1.0, \mathrm{C}-1), 115.7(\mathrm{C}-3), 72.6\left(\mathrm{~d}, J=159.0, C\left(\mathrm{CH}_{3}\right)_{2}\right)$, $61.5\left(\mathrm{~d}, J=7.1 \mathrm{~Hz}, \mathrm{OCH}_{2} \mathrm{CH}_{3}\right), 22.3\left(\mathrm{~d}, J=1.0 \mathrm{~Hz}, \mathrm{C}\left(\mathrm{CH}_{3}\right)_{2}\right), 16.4\left(\mathrm{~d}, J=6.0 \mathrm{~Hz}, \mathrm{OCH}_{2} \mathrm{CH}_{3}\right) ;{ }^{31} \mathrm{P}$ NMR (121 MHz, $\left.\mathrm{CDCl}_{3}\right) \delta$ 23.96. HRMS-ESI: calcd for $\mathrm{C}_{14} \mathrm{H}_{23} \mathrm{NO}_{5} \mathrm{P}^{+}[\mathrm{M}+\mathrm{H}]^{+} 316.1308$; found 316.1311.

2-(Diethoxyphosphoryl)-N-(3,4-dihydroxybenzylidene)propan-2-amine oxide (3,4-OH-PPN; 4d). The title compound was obtained from 3 (500 mg, $2.4 \mathrm{mmol})$ and 3,4-dihydroxybenzaldehyde (400 mg, 2.4 $\mathrm{mmol})$ in DCE $(20 \mathrm{~mL})$ as a brown solid from $\mathrm{Et}_{2} \mathrm{O}(0.56 \mathrm{~g}, 70 \%), \mathrm{mp} 172.8^{\circ} \mathrm{C}:{ }^{1} \mathrm{H} \mathrm{NMR}(300 \mathrm{MHz}$, DMSO-d6) $\delta 8.70($ br s, $1 \mathrm{H}, H \mathrm{C}=\mathrm{NO}), 7.62(\mathrm{~d}, J=1.7 \mathrm{~Hz}, 1 \mathrm{H}, \mathrm{H}-2), 7.47(\mathrm{dd}, J=8.3$ and $J=1.7 \mathrm{~Hz}$ 
1H, H-6), 6.77 (d, $J=8.3 \mathrm{~Hz}, 1 \mathrm{H}, \mathrm{H}-5), 4.07\left(\mathrm{~m}, 4 \mathrm{H}, 2 \times \mathrm{OCH}_{2} \mathrm{CH}_{3}\right), 1.69\left(\mathrm{~s}, 3 \mathrm{H}, \mathrm{C}\left(\mathrm{CH}_{3}\right)_{2}\right), 1.64(\mathrm{~s}$, $\left.3 \mathrm{H}, \mathrm{C}\left(\mathrm{CH}_{3}\right)_{2}\right), 1.22\left(\mathrm{t}, J=7.0 \mathrm{~Hz}, 6 \mathrm{H}, 2 \times \mathrm{OCH}_{2} \mathrm{CH}_{3}\right) ;{ }^{13} \mathrm{C} \mathrm{NMR}(75 \mathrm{MHz}, \mathrm{DMSO}-d 6) \delta 144.9(\mathrm{C}-3$ and C-4), $132.1(\mathrm{~d}, J=6.0 \mathrm{~Hz}, \mathrm{HC}=\mathrm{NO}), 123.2(\mathrm{C}-1), 122.6(\mathrm{C}-6), 116.1(\mathrm{C}-2), 115.7(\mathrm{C}-5), 72.5(\mathrm{~d}, J=$

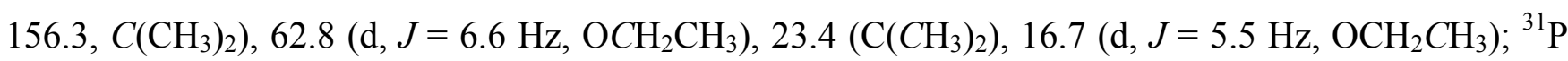
NMR (121 MHz, DMSO-d6) $\delta$ 23.67. HRMS-ESI: calcd for $\mathrm{C}_{14} \mathrm{H}_{23} \mathrm{NO}_{6} \mathrm{P}^{+}[\mathrm{M}+\mathrm{H}]^{+} 332.1258$, found 332.1258.

2-(Diethoxyphosphoryl)-N-(3,5-dihydroxybenzylidene)propan-2-amine oxide (3,5-OH-PPN; 4e). The title compound was obtained from $3(600 \mathrm{mg}, 2.85 \mathrm{mmol})$ and 3,5-dihydroxybenzaldehyde $(0.35 \mathrm{~g}, 2.85$ $\mathrm{mmol})$ in DCE $(20 \mathrm{~mL})$ as a white solid from $\mathrm{CH}_{2} \mathrm{Cl}_{2}(0.45 \mathrm{~g}, 55 \%), \mathrm{mp} 180.2{ }^{\circ} \mathrm{C}:{ }^{1} \mathrm{H} \mathrm{NMR}(300 \mathrm{MHz}$, DMSO-do) $\delta 9.34$ (br s, 2H, OH), 7.66 (d, $J=2.4 \mathrm{~Hz}, 1 \mathrm{H}, H \mathrm{C}=\mathrm{NO}), 7.24$ (d, $J=2.2 \mathrm{~Hz}, 2 \mathrm{H}, \mathrm{H}-2), 6.29$ $(\mathrm{t}, J=2.2 \mathrm{~Hz}, 1 \mathrm{H}, \mathrm{H}-4), 4.08\left(\mathrm{~m}, 4 \mathrm{H}, 2 \times \mathrm{OCH}_{2} \mathrm{CH}_{3}\right), 1.71\left(\mathrm{~s}, 3 \mathrm{H}, \mathrm{C}\left(\mathrm{CH}_{3}\right)_{2}\right), 1.66\left(\mathrm{~s}, 3 \mathrm{H}, \mathrm{C}\left(\mathrm{CH}_{3}\right)_{2}\right), 1.23$ $\left(\mathrm{t}, J=7.1 \mathrm{~Hz}, 6 \mathrm{H}, 2 \times \mathrm{OCH}_{2} \mathrm{CH}_{3}\right) ;{ }^{13} \mathrm{C} \mathrm{NMR}(75 \mathrm{MHz}, \mathrm{DMSO}-d 6) \delta 158.4(\mathrm{C}-3), 132.5(\mathrm{~d}, J=1.7 \mathrm{~Hz}$, C-1), $132.0(\mathrm{~d}, J=6.0 \mathrm{~Hz}, \mathrm{HC}=\mathrm{NO}), 107.4(\mathrm{C}-2), 105.3(\mathrm{C}-4), 72.9\left(\mathrm{~d}, \mathrm{~J}=155.7 \mathrm{~Hz}, C\left(\mathrm{CH}_{3}\right)_{2}\right), 62.6(\mathrm{~d}$,

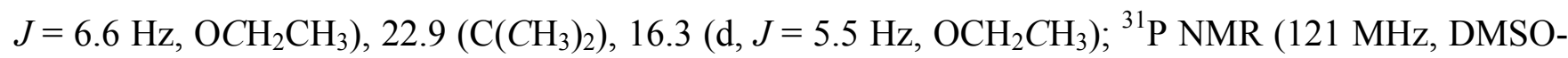
d6) $\delta$ 23.26. HRMS-ESI: calcd for $\mathrm{C}_{14} \mathrm{H}_{23} \mathrm{NO}_{6} \mathrm{P}^{+}[\mathrm{M}+\mathrm{H}]^{+} 332.1258$, found 332.1259.

2-(Diethoxyphosphoryl)-N-(2,4-dihydroxybenzylidene)propan-2-amine oxide (2,4-OH-PPN; 4f). The title compound was obtained from $3(500 \mathrm{mg}, 2.4 \mathrm{mmol})$ and 2,4-dihydroxybenzaldehyde (330 mg, 2.4 $\mathrm{mmol})$ in THF $(15 \mathrm{~mL})$ as a white powder from $\mathrm{Et}_{2} \mathrm{O}(0.29 \mathrm{~g}, 36 \%), \mathrm{mp} 133.3{ }^{\circ} \mathrm{C}:{ }^{1} \mathrm{H} \mathrm{NMR}(300 \mathrm{MHz}$, DMSO-d6) $\delta 7.94(\mathrm{~d}, J=2.4 \mathrm{~Hz}, 1 \mathrm{H}, H \mathrm{C}=\mathrm{NO}), 7.38(\mathrm{~d}, J=8.7 \mathrm{~Hz}, 1 \mathrm{H}, \mathrm{H}-6), 6.30(\mathrm{dd}, J=8.3$ and $J=$ $2.2 \mathrm{~Hz}, 1 \mathrm{H}, \mathrm{H}-5), 6.16(\mathrm{~d}, J=2.2 \mathrm{~Hz}, 1 \mathrm{H}, \mathrm{H}-3), 4.08\left(\mathrm{~m}, 4 \mathrm{H}, 2 \times \mathrm{OCH}_{2} \mathrm{CH}_{3}\right), 1.72\left(\mathrm{~s}, 3 \mathrm{H}, \mathrm{C}\left(\mathrm{CH}_{3}\right)_{2}\right)$, $1.68\left(\mathrm{~s}, 3 \mathrm{H}, \mathrm{C}\left(\mathrm{CH}_{3}\right)_{2}\right), 1.24\left(\mathrm{t}, J=7.1 \mathrm{~Hz}, 6 \mathrm{H}, 2 \times \mathrm{OCH}_{2} \mathrm{CH}_{3}\right) ;{ }^{13} \mathrm{C}$ NMR $(75 \mathrm{MHz}, \mathrm{DMSO}-d 6) \delta 163.4$ (C-2), 161.4 (C-4), 139.2 (d, $J=5.5$ Hz, HC=NO), 135.1 (C-6), 108.9 (C-1), 107.5 (C-5), 104.3 (C-3),

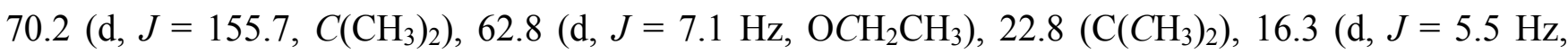
$\left.\mathrm{OCH}_{2} \mathrm{CH}_{3}\right) ;{ }^{31} \mathrm{P}$ NMR (121 MHz, DMSO-d6) $\delta$ 22.82. HRMS-ESI: calcd for $\mathrm{C}_{14} \mathrm{H}_{23} \mathrm{NO}_{6} \mathrm{P}^{+}[\mathrm{M}+\mathrm{H}]^{+}$ 332.1258, found 332.1257. 
2-(Diethoxyphosphoryl)-N-(3,4,5-trihydroxybenzylidene)propan-2-amine oxide (3,4,5-OH-PPN; 4g).

The title compound was obtained from $3(500 \mathrm{mg}, 2.4 \mathrm{mmol})$ and 3,4,5-trihydroxybenzaldehyde (400 $\mathrm{mg}, 2.4 \mathrm{mmol})$ in DCE $(15 \mathrm{~mL})$ as a brown pale powder from ethylacetate $(0.28 \mathrm{~g}, 35 \%), \mathrm{mp}>170{ }^{\circ} \mathrm{C}$ : ${ }^{1} \mathrm{H}$ NMR (400 MHz, DMSO-d6) $\delta 9.03$ (br s, 2H, HO-C-3), 8.70 (b rs, 1H, HO-C-4), 7.52 (d, $J=2.5$ $\mathrm{Hz}, 1 \mathrm{H}, \mathrm{HC}=\mathrm{NO}), 7.38(\mathrm{~s}, 2 \mathrm{H}, \mathrm{H}-2), 4.07\left(\mathrm{~m}, 4 \mathrm{H}, 2 \times \mathrm{OCH}_{2} \mathrm{CH}_{3}\right), 1.69\left(\mathrm{~s}, 3 \mathrm{H}, \mathrm{C}\left(\mathrm{CH}_{3}\right)_{2}\right), 1.64(\mathrm{~s}, 3 \mathrm{H}$, $\left.\mathrm{C}\left(\mathrm{CH}_{3}\right)_{2}\right), 1.23\left(\mathrm{t}, J=7.1 \mathrm{~Hz}, 6 \mathrm{H}, 2 \times \mathrm{OCH}_{2} \mathrm{CH}_{3}\right) ;{ }^{13} \mathrm{C}$ NMR $(75 \mathrm{MHz}, \mathrm{DMSO}-d 6) \delta 145.6(\mathrm{C}-3), 136.3$ (C-4), $131.8(\mathrm{~d}, J=6.1 \mathrm{~Hz}, \mathrm{HC}=\mathrm{NO}), 121.9(\mathrm{C}-1), 108.9(\mathrm{C}-2), 72.1\left(\mathrm{~d}, J=156.3 \mathrm{~Hz}, C\left(\mathrm{CH}_{3}\right)_{2}\right), 62.4$ $\left(\mathrm{d}, J=6.6 \mathrm{~Hz}, \mathrm{OCH}_{2} \mathrm{CH}_{3}\right), 23.0\left(\mathrm{C}\left(\mathrm{CH}_{3}\right)_{2}\right), 16.3\left(\mathrm{~d}, J=5.5 \mathrm{~Hz}, \mathrm{OCH}_{2} \mathrm{CH}_{3}\right) ;{ }^{31} \mathrm{P} \mathrm{NMR}(121 \mathrm{MHz}$, DMSO-d6) $\delta$ 23.68. HRMS-ESI: calcd for $\mathrm{C}_{14} \mathrm{H}_{23} \mathrm{NO}_{7} \mathrm{P}^{+}[\mathrm{M}+\mathrm{H}]^{+} 348.1207$, found 348.1205.

2-(Diethoxyphosphoryl)-N-(4-hydroxy-3-methoxybenzylidene)propan-2-amine oxide (4-OH-3-OMe$P P N ; 4 \boldsymbol{h})$. The title compound was obtained from 3 (500 mg, $2.4 \mathrm{mmol}$ ) and 4-hydroxy-3methoxybenzaldehyde $(0.36 \mathrm{~g}, 2.4 \mathrm{mmol})$ in DCE $(15 \mathrm{~mL})$ as a white powder from $\mathrm{Et}_{2} \mathrm{O}(0.4 \mathrm{~g}, 49 \%)$, mp $128.5{ }^{\circ} \mathrm{C}:{ }^{1} \mathrm{H}$ NMR (400 MHz, $\left.\mathrm{CDCl}_{3}\right) \delta 8.57(\mathrm{~d}, J=1.8 \mathrm{~Hz}, 1 \mathrm{H}, \mathrm{H}-2), 7.68(\mathrm{~d}, J=2.8 \mathrm{~Hz}, 1 \mathrm{H}$, $H \mathrm{C}=\mathrm{NO}), 7.31(\mathrm{dd}, J=8.3$ and $J=1.8 \mathrm{~Hz}, 1 \mathrm{H}, \mathrm{H}-6), 6.94(\mathrm{~d}, J=8.3 \mathrm{~Hz}, 1 \mathrm{H}, \mathrm{H}-5), 4.21(\mathrm{~m}, 4 \mathrm{H}, 2 \times$ $\left.\mathrm{OCH}_{2} \mathrm{CH}_{3}\right), 3.95\left(\mathrm{~s}, 3 \mathrm{H}, \mathrm{OCH}_{3}\right), 1.85\left(\mathrm{~s}, 3 \mathrm{H}, \mathrm{C}\left(\mathrm{CH}_{3}\right)_{2}\right), 1.83\left(\mathrm{~s}, 3 \mathrm{H}, \mathrm{C}\left(\mathrm{CH}_{3}\right)_{2}\right), 1.33(\mathrm{t}, J=7.0 \mathrm{~Hz}, 6 \mathrm{H}, 2$ $\left.\times \mathrm{OCH}_{2} \mathrm{CH}_{3}\right) ;{ }^{13} \mathrm{C} \mathrm{NMR}\left(75 \mathrm{MHz}, \mathrm{CDCl}_{3}\right) \delta 147.9(\mathrm{C}-3), 146.0(\mathrm{C}-4), 133.7(\mathrm{~d}, J=5.5, \mathrm{HC}=\mathrm{NO})$, 124.5 (C-6), $123.5(\mathrm{C}-1), 114.3(\mathrm{C}-5), 72.1\left(\mathrm{~d}, J=154.0, C\left(\mathrm{CH}_{3}\right)_{2}\right), 63.4\left(\mathrm{~d}, J=7.2 \mathrm{~Hz}, \mathrm{OCH}_{2} \mathrm{CH}_{3}\right)$,

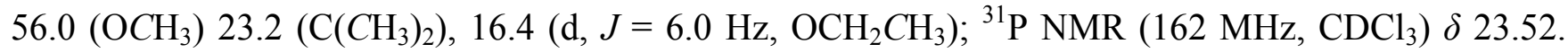
HRMS-ESI: calcd for $\mathrm{C}_{15} \mathrm{H}_{25} \mathrm{NO}_{6} \mathrm{P}^{+}[\mathrm{M}+\mathrm{H}]^{+}$346.1414, found 346.1413.

2-(Diethoxyphosphoryl)-N-(4-hydroxy-3,5-dimethoxybenzylidene)propan-2-amine oxide (4-OH-3,5$O M e-P P N ; 4 i)$. The title compound was obtained from 3 (500 mg, $2.4 \mathrm{mmol})$ and 4-hydroxy-3,5dimethoxybenzaldehyde $(290 \mathrm{mg}, 2.4 \mathrm{mmol})$ in DCE $(15 \mathrm{~mL})$ as a white solid from ethyl acetate $(0.28$ g, 57\%), mp $139.2{ }^{\circ} \mathrm{C}:{ }^{1} \mathrm{H}$ NMR $\left(300 \mathrm{MHz}, \mathrm{CDCl}_{3}\right) \delta 7.67$ (br s, $\left.1 \mathrm{H}, H \mathrm{C}=\mathrm{NO}\right), 7.61(\mathrm{~s}, 2 \mathrm{H}, \mathrm{H}-2), 4.20$ $\left(\mathrm{m}, 4 \mathrm{H}, 2 \times \mathrm{OCH}_{2} \mathrm{CH}_{3}\right), 3.86\left(\mathrm{~s}, 6 \mathrm{H}, \mathrm{OCH}_{3}\right), 1.77\left(\mathrm{~s}, 3 \mathrm{H}, \mathrm{C}\left(\mathrm{CH}_{3}\right)_{2}\right), 1.75\left(\mathrm{~s}, 3 \mathrm{H}, \mathrm{C}\left(\mathrm{CH}_{3}\right)_{2}\right), 1.26(\mathrm{t}, J=$ $\left.6.9 \mathrm{~Hz}, 6 \mathrm{H}, 2 \times \mathrm{OCH}_{2} \mathrm{CH}_{3}\right) ;{ }^{13} \mathrm{C} \mathrm{NMR}\left(75 \mathrm{MHz}, \mathrm{CDCl}_{3}\right) \delta 146.6(\mathrm{C}-3), 137.2(\mathrm{C}-4), 134.0$ (br s, $\mathrm{HC}=\mathrm{NO}), 122.3(\mathrm{C}-1), 106.6(\mathrm{C}-2), 72.1\left(\mathrm{~d}, J=153.5, C\left(\mathrm{CH}_{3}\right)_{2}\right), 63.4\left(\mathrm{~d}, J=6.6 \mathrm{~Hz}, \mathrm{OCH}_{2} \mathrm{CH}_{3}\right), 56.3$ 


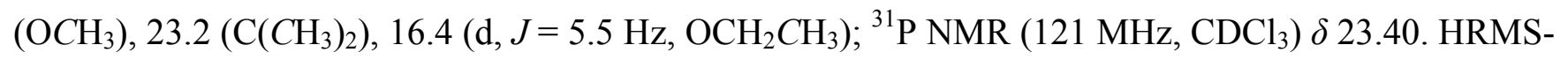
ESI: calcd for $\mathrm{C}_{16} \mathrm{H}_{27} \mathrm{NO}_{7} \mathrm{P}^{+}[\mathrm{M}+\mathrm{H}]^{+} 376.1520$, found 376.1518 .

2-(Diethoxyphosphoryl)-N-(2-nitrobenzylidene)propan-2-amine oxide (2-NO2-PPN; 4j). The title compound was obtained from $3(400 \mathrm{mg}, 1.9 \mathrm{mmol})$ and 2-nitrobenzaldehyde $(0.29 \mathrm{~g}, 1.9 \mathrm{mmol})$ in DCE $(20 \mathrm{~mL})$ as a yellow oil $(0.29 \mathrm{~g}, 46 \%):{ }^{1} \mathrm{H}$ NMR $\left(300 \mathrm{MHz}, \mathrm{CDCl}_{3}\right) \delta 9.01(\mathrm{~d}, J=8.1 \mathrm{~Hz}, 1 \mathrm{H}, \mathrm{H}-$ 3), $8.32(\mathrm{~d}, J=2.0 \mathrm{~Hz}, 1 \mathrm{H}, H \mathrm{C}=\mathrm{NO}), 8.03(\mathrm{~d}, J=8.3 \mathrm{~Hz}, 1 \mathrm{H}, \mathrm{H}-6), 7.68(\mathrm{t}, J=7.7 \mathrm{~Hz}, 1 \mathrm{H}, \mathrm{H}-4), 7.52(\mathrm{t}$, $J=7.5 \mathrm{~Hz}, 1 \mathrm{H}, \mathrm{H}-5), 4.24\left(\mathrm{~m}, 4 \mathrm{H}, 2 \times \mathrm{OCH}_{2} \mathrm{CH}_{3}\right), 1.88\left(\mathrm{~s}, 3 \mathrm{H}, \mathrm{C}\left(\mathrm{CH}_{3}\right)_{2}\right), 1.83\left(\mathrm{~s}, 3 \mathrm{H}, \mathrm{C}(\mathrm{CH})_{2}\right), 1.36(\mathrm{t}$, $\left.J=7.2 \mathrm{~Hz}, 6 \mathrm{H}, 2 \times \mathrm{OCH}_{2} \mathrm{CH}_{3}\right) ;{ }^{13} \mathrm{C} \mathrm{NMR}\left(75 \mathrm{MHz}, \mathrm{CDCl}_{3}\right) \delta 147.5(\mathrm{C}-2), 133.3(\mathrm{C}-5), 130.1(\mathrm{C}-4)$, $129.7(\mathrm{C}-6), 127.3$ (d, $J=4.9 \mathrm{~Hz}, \mathrm{HC}=\mathrm{NO}), 124.8(\mathrm{C}-3), 124.6(\mathrm{~d}, J=1.6 \mathrm{~Hz}, \mathrm{C}-1), 74.2(\mathrm{~d}, J=154.6$ $\left.\mathrm{Hz}, C\left(\mathrm{CH}_{3}\right)_{2}\right), 63.5\left(\mathrm{~d}, J=6.6 \mathrm{~Hz}, \mathrm{OCH}_{2} \mathrm{CH}_{3}\right), 23.2\left(\mathrm{C}_{2}\left(\mathrm{CH}_{3}\right)_{2}\right), 16.4\left(\mathrm{~d}, J=6.0 \mathrm{~Hz}, \mathrm{OCH}_{2} \mathrm{CH}_{3}\right) ;{ }^{31} \mathrm{P}$ NMR (121 MHz, $\left.\mathrm{CDCl}_{3}\right) \delta$ 22.34. HRMS-ESI: calcd for $\mathrm{C}_{14} \mathrm{H}_{22} \mathrm{~N}_{2} \mathrm{O}_{6} \mathrm{P}^{+}[\mathrm{M}+\mathrm{H}]^{+} 345.1210$, found 345.1209.

2-(Diethoxyphosphoryl)-N-(3-nitrobenzylidene)propan-2-amine oxide (3-NO2-PPN; $4 \boldsymbol{k})$. The title compound was obtained from $3(500 \mathrm{mg}, 2.4 \mathrm{mmol})$ and 3-nitrobenzaldehyde $(0.36 \mathrm{~g} 2.4 \mathrm{mmol})$ in DCE $(15 \mathrm{~mL})$ as white crystals from $\mathrm{Et}_{2} \mathrm{O} /$ pentane, $50: 50(0.67 \mathrm{~g}, 87 \%) \mathrm{mp} 80.2{ }^{\circ} \mathrm{C}:{ }^{1} \mathrm{H} \mathrm{NMR}(300 \mathrm{MHz}$, $\left.\mathrm{CDCl}_{3}\right) \delta 9.18$ (br s, $\left.1 \mathrm{H}, \mathrm{H}-2\right), 8.58$ (br d, $\left.J=8.0 \mathrm{~Hz}, 1 \mathrm{H}, \mathrm{H}-2\right), 8.23$ (br d, $\left.J=8.0 \mathrm{~Hz}, 1 \mathrm{H}, \mathrm{H}-6\right), 7.91$ (d, $J=2.6 \mathrm{~Hz}, 1 \mathrm{H}, H \mathrm{C}=\mathrm{NO}), 7.58(\mathrm{t}, J=8.0 \mathrm{~Hz}, 1 \mathrm{H}, \mathrm{H}-5), 4.21\left(\mathrm{~m}, 4 \mathrm{H}, 2 \times \mathrm{OCH}_{2} \mathrm{CH}_{3}\right), 1.88(\mathrm{~s}, 3 \mathrm{H}$, $\left.\mathrm{C}\left(\mathrm{CH}_{3}\right)_{2}\right), 1.83\left(\mathrm{~s}, 3 \mathrm{H}, \mathrm{C}\left(\mathrm{CH}_{3}\right)_{2}\right), 1.34\left(\mathrm{t}, J=7.3 \mathrm{~Hz}, 6 \mathrm{H}, 2 \times \mathrm{OCH}_{2} \mathrm{CH}_{3}\right) ;{ }^{13} \mathrm{C} \mathrm{NMR}\left(75 \mathrm{MHz}, \mathrm{CDCl}_{3}\right) \delta$ 148.3 (C-3), 134.1 (C-6), 132.1 (C-1), 131.2 (d, $J=6.0 \mathrm{~Hz}, \mathrm{HC}=\mathrm{NO}), 129.4$ (C-6), 124.5 (C-2), 123.3 $\left.(\mathrm{C}-4), 73.6\left(\mathrm{~d}, J=154.1 \mathrm{~Hz}, C\left(\mathrm{CH}_{3}\right)_{2}\right), 63.6\left(\mathrm{~d}, J=7.2 \mathrm{~Hz}, \mathrm{OCH}_{2} \mathrm{CH}_{3}\right), 23.2\left(\mathrm{C}_{\left(C \mathrm{H}_{3}\right.}\right)_{2}\right), 16.4(\mathrm{~d}, J=5.5$ $\left.\mathrm{Hz}, \mathrm{OCH}_{2} \mathrm{CH}_{3}\right) ;{ }^{31} \mathrm{P}$ NMR $\left(121 \mathrm{MHz}, \mathrm{CDCl}_{3}\right) \delta$ 22.52. HRMS-ESI: calcd for $\mathrm{C}_{14} \mathrm{H}_{22} \mathrm{~N}_{2} \mathrm{O}_{6} \mathrm{P}^{+}[\mathrm{M}+\mathrm{H}]^{+}$ 345.1210 , found 345.1212 .

2-(Diethoxyphosphoryl)-N-(4-nitrobenzylidene)propan-2-amine oxide (4-NO2-PPN; 4l). The title compound was obtained from $3(600 \mathrm{mg}, 2.85 \mathrm{mmol})$ and 4-nitrobenzaldehyde $(0.43 \mathrm{~g} 2.85 \mathrm{mmol})$ in DCE $(20 \mathrm{~mL})$ as a white solid from $\mathrm{Et}_{2} \mathrm{O} / \mathrm{DCM}, 70: 30(0.44 \mathrm{~g}, 46 \%)$, mp $139.9{ }^{\circ} \mathrm{C}\left(\mathrm{litt} .{ }^{30} 139.9{ }^{\circ} \mathrm{C}\right):{ }^{1} \mathrm{H}$ $\operatorname{NMR}\left(300 \mathrm{MHz}, \mathrm{CDCl}_{3}\right) \delta 8.44(\mathrm{~d}, J=9.1 \mathrm{~Hz}, 2 \mathrm{H}, \mathrm{H}-3), 8.26(\mathrm{~d}, J=9.1 \mathrm{~Hz}, 2 \mathrm{H}, \mathrm{H}-2), 7.92(\mathrm{~d}, J=2.7$ 
$\mathrm{Hz} 1 \mathrm{H}, H \mathrm{C}=\mathrm{NO}), 4.21\left(\mathrm{~m}, 4 \mathrm{H}, 2 \times \mathrm{OCH}_{2} \mathrm{CH}_{3}\right), 1.89\left(\mathrm{~s}, 3 \mathrm{H}, \mathrm{C}\left(\mathrm{CH}_{3}\right)_{2}\right), 1.84\left(\mathrm{~s}, 3 \mathrm{H}, \mathrm{C}\left(\mathrm{CH}_{3}\right)_{2}\right), 1.34(\mathrm{t}, J$ $\left.=7.0 \mathrm{~Hz}, 6 \mathrm{H}, 2 \times \mathrm{OCH}_{2} \mathrm{CH}_{3}\right) ;{ }^{13} \mathrm{C} \mathrm{NMR}\left(75 \mathrm{MHz}, \mathrm{CDCl}_{3}\right) \delta 147.8(\mathrm{C}-4), 136.2(\mathrm{~d}, J=1.5 \mathrm{~Hz}, \mathrm{C}-1)$, $131.5(\mathrm{~d}, J=4.4 \mathrm{~Hz}, \mathrm{HC}=\mathrm{NO}), 129.2(\mathrm{C}-2), 123.7(\mathrm{C}-3), 74.0\left(\mathrm{~d}, J=153.5 \mathrm{~Hz}, C\left(\mathrm{CH}_{3}\right)_{2}\right), 63.6(\mathrm{~d}, J=$

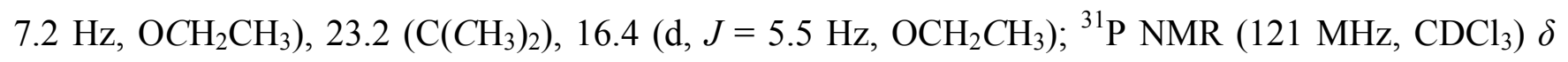
22.38. HRMS-ESI: calcd for $\mathrm{C}_{14} \mathrm{H}_{22} \mathrm{~N}_{2} \mathrm{O}_{6} \mathrm{P}^{+}[\mathrm{M}+\mathrm{H}]^{+}$345.1210, found 345.1210.

2-(Diethoxyphosphoryl)-N-(4-acetamidobenzylidene)propan-2-amine oxide (4-NHAc-PPN; 4m). The title compound was obtained from $3(600 \mathrm{mg}, 2.85 \mathrm{mmol})$ and 4-acetamidobenzaldehyde $(0.39 \mathrm{~g} 2.85$ $\mathrm{mmol})$ in DCE $(15 \mathrm{~mL})$ as a white powder from $\mathrm{Et}_{2} \mathrm{O}(0.60 \mathrm{~g}, 73 \%), \mathrm{mp} 154.7{ }^{\circ} \mathrm{C}:{ }^{1} \mathrm{H} \mathrm{NMR}(300 \mathrm{MHz}$, DMSO-d6) $\delta 10.15(\mathrm{~s}, 1 \mathrm{H}, \mathrm{NH}), 8.28(\mathrm{~d}, J=8.8 \mathrm{~Hz}, 2 \mathrm{H}, \mathrm{H}-3), 7.80(\mathrm{~d}, J=2.4 \mathrm{~Hz}, 1 \mathrm{H}, H \mathrm{C}=\mathrm{NO}), 7.63$ $(\mathrm{d}, J=8.8 \mathrm{~Hz}, 2 \mathrm{H}, \mathrm{H}-2), 4.07\left(\mathrm{~m}, 4 \mathrm{H}, 2 \times \mathrm{OCH}_{2} \mathrm{CH}_{3}\right), 2.05\left(\mathrm{~s}, 3 \mathrm{H}, \mathrm{CH}_{3}\right), 1.72\left(\mathrm{~s}, 3 \mathrm{H}, \mathrm{C}\left(\mathrm{CH}_{3}\right)_{2}\right), 1.67(\mathrm{~s}$, $\left.3 \mathrm{H}, \mathrm{C}\left(\mathrm{CH}_{3}\right)_{2}\right), 1.22\left(\mathrm{t}, J=7.0 \mathrm{~Hz}, 6 \mathrm{H}, 2 \times \mathrm{OCH}_{2} \mathrm{CH}_{3}\right) ;{ }^{13} \mathrm{C} \mathrm{NMR}(75 \mathrm{MHz}, \mathrm{DMSO}-d 0) \delta 169.1(\mathrm{CO})$, $141.2(\mathrm{C}-4), 131.7$ (d, $J=6.0 \mathrm{~Hz}, \mathrm{HC}=\mathrm{NO}), 130.0(\mathrm{C}-2), 126.3(\mathrm{C}-1), 118.6(\mathrm{C}-3), 72.4(\mathrm{~d}, J=155.7$

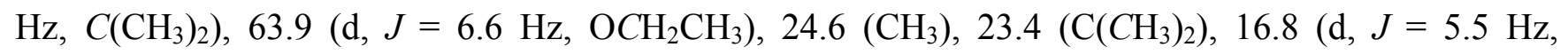
$\left.\mathrm{OCH}_{2} \mathrm{CH}_{3}\right) ;{ }^{31} \mathrm{P}$ NMR (121 MHz, DMSO-d6) $\delta$ 23.39. HRMS-ESI: calcd for $\mathrm{C}_{16} \mathrm{H}_{26} \mathrm{~N}_{2} \mathrm{O}_{5} \mathrm{P}^{+}[\mathrm{M}+\mathrm{H}]^{+}$ 357.1574 , found 357.1572 .

2-(Diethoxyphosphoryl)-N-(4-carboxybenzylidene)propan-2-amine oxide (4-CO $\left.\mathrm{O}_{2} \mathrm{H}-\mathrm{PPN} ; \quad 4 \boldsymbol{n}\right)$. The title compound was obtained from 3 (400 mg, $2.0 \mathrm{mmol})$ and 4-carboxybenzaldehyde (0.29 g $2.0 \mathrm{mmol})$ in DCE $(12.5 \mathrm{~mL})$ as a white powder from $\mathrm{Et}_{2} \mathrm{O}(0.43 \mathrm{~g}, 66 \%), \mathrm{mp} 141.9{ }^{\circ} \mathrm{C}:{ }^{1} \mathrm{H} \mathrm{NMR}(400 \mathrm{MHz}$, $\left.\mathrm{CDCl}_{3}\right) \delta 8.16(\mathrm{~d}, J=8.3 \mathrm{~Hz}, 2 \mathrm{H}, \mathrm{H}-3), 7.75(\mathrm{~d}, J=8.3 \mathrm{~Hz}, 2 \mathrm{H}, \mathrm{H}-2), 7.68(\mathrm{~d}, J=2.4 \mathrm{~Hz}, 1 \mathrm{H}, H \mathrm{C}=\mathrm{NO})$, $4.30\left(\mathrm{~m}, 4 \mathrm{H}, 2 \times \mathrm{OCH}_{2} \mathrm{CH}_{3}\right), 1.91\left(\mathrm{~s}, 3 \mathrm{H}, \mathrm{C}\left(\mathrm{CH}_{3}\right)_{2}\right), 1.86\left(\mathrm{~s}, 3 \mathrm{H}, \mathrm{C}\left(\mathrm{CH}_{3}\right)_{2}\right), 1.39(\mathrm{t}, J=7.0 \mathrm{~Hz}, 6 \mathrm{H}, 2 \times$ $\left.\mathrm{OCH}_{2} \mathrm{CH}_{3}\right) ;{ }^{13} \mathrm{C} \mathrm{NMR}\left(75 \mathrm{MHz}, \mathrm{CDCl}_{3}\right) \delta 167.9(\mathrm{CO}), 133.9(\mathrm{~d}, J=1.1 \mathrm{~Hz}, \mathrm{C}-1), 132.5(\mathrm{~d}, J=6.0 \mathrm{~Hz}$, $\mathrm{HC}=\mathrm{NO}), 131.5(\mathrm{C}-4), 129.9(\mathrm{C}-2), 128.5(\mathrm{C}-3), 74.0\left(\mathrm{~d}, J=157.9 \mathrm{~Hz}, C\left(\mathrm{CH}_{3}\right)_{2}\right), 63.8(\mathrm{~d}, J=7.1 \mathrm{~Hz}$, $\left.\mathrm{OCH}_{2} \mathrm{CH}_{3}\right), 23.3\left(\mathrm{C}\left(\mathrm{CH}_{3}\right)_{2}\right), 16.4\left(\mathrm{~d}, J=6.0 \mathrm{~Hz}, \mathrm{OCH}_{2} \mathrm{CH}_{3}\right) ;{ }^{31} \mathrm{P} \mathrm{NMR}\left(162 \mathrm{MHz}, \mathrm{CDCl}_{3}\right) \delta 23.61$. HRMS-ESI: calcd for $\mathrm{C}_{15} \mathrm{H}_{23} \mathrm{NO}_{6} \mathrm{P}^{+}[\mathrm{M}+\mathrm{H}]^{+}$344.1258, found 344.1260.

2-(Diethoxyphosphoryl)-N-(4-ethoxycarbonylbenzylidene)propan-2-amine oxide (4-CO $\left.\mathrm{Et}_{2} \mathrm{PPN} ; 4 \boldsymbol{0}\right)$. The title compound was obtained from $3(300 \mathrm{mg}, 1.4 \mathrm{mmol})$ and ethyl-4-formylbenzoate (253 mg, 1.4 
mmol) in DCE $(12.5 \mathrm{~mL})$ as a yellow oil $(0.40 \mathrm{~g}, 76 \%):{ }^{1} \mathrm{H}$ NMR $\left(300 \mathrm{MHz}, \mathrm{CDCl}_{3}\right) \delta 8.35(\mathrm{~d}, J=7.3$ $\mathrm{Hz}, 2 \mathrm{H}, \mathrm{H}-3), 8.07$ (d, $J=7.3 \mathrm{~Hz}, 2 \mathrm{H}, \mathrm{H}-2), 7.80(\mathrm{~d}, J=2.2 \mathrm{~Hz}, 1 \mathrm{H}, H \mathrm{C}=\mathrm{NO}), 4.35$ (q, $J=7.3 \mathrm{~Hz}, 2 \mathrm{H}$, $\left.\mathrm{CO}_{2} \mathrm{CH}_{2} \mathrm{CH}_{3}\right), 4.20\left(\mathrm{~m}, 4 \mathrm{H}, \mathrm{P}\left(\mathrm{OCH}_{2} \mathrm{CH}_{3}\right)_{2}\right), 1.87\left(\mathrm{~s}, 3 \mathrm{H}, \mathrm{C}\left(\mathrm{CH}_{3}\right)_{2}\right), 1.82\left(\mathrm{~s}, 3 \mathrm{H}, \mathrm{C}\left(\mathrm{CH}_{3}\right)_{2}\right), 1.37(\mathrm{t}, J=$ $\left.7.3 \mathrm{~Hz}, 3 \mathrm{H}, \mathrm{CO}_{2} \mathrm{CH}_{2} \mathrm{CH}_{3}\right), 1.31\left(\mathrm{t}, J=7.0 \mathrm{~Hz}, 6 \mathrm{H}, \mathrm{P}\left(\mathrm{OCH}_{2} \mathrm{CH}_{3}\right)_{2}\right) ;{ }^{13} \mathrm{C} \mathrm{NMR}\left(75 \mathrm{MHz}, \mathrm{CDCl}_{3}\right) \delta 165.9$ (CO), 133.4 (d, $J=2.3 \mathrm{~Hz}, \mathrm{C}-1), 132.5$ (d, $J=6.0 \mathrm{~Hz}, \mathrm{HC}=\mathrm{NO}), 131.5$ (C-4), $129.6(\mathrm{C}-2), 128.6$ (C-3), $73.4\left(\mathrm{~d}, J=153.0 \mathrm{~Hz}, C\left(\mathrm{CH}_{3}\right)_{2}\right), 63.5\left(\mathrm{~d}, J=7.5 \mathrm{~Hz}, \mathrm{P}\left(\mathrm{OCH}_{2} \mathrm{CH}_{3}\right)_{2}\right), 61.1\left(\mathrm{CO}_{2} \mathrm{CH}_{2} \mathrm{CH}_{3}\right), 23.2$ $\left(\mathrm{C}\left(\mathrm{CH}_{3}\right)_{2}\right), 16.5\left(\mathrm{~d}, J=6.0 \mathrm{~Hz}, \mathrm{P}\left(\mathrm{OCH}_{2} \mathrm{CH}_{3}\right)_{2}\right), 14.3\left(\mathrm{CO}_{2} \mathrm{CH}_{2} \mathrm{CH}_{3}\right) ;{ }^{31} \mathrm{P} \mathrm{NMR}\left(121 \mathrm{MHz}, \mathrm{CDCl}_{3}\right) \delta$ 22.74. HRMS-ESI: calcd for $\mathrm{C}_{17} \mathrm{H}_{26} \mathrm{NO}_{6} \mathrm{P}^{+}[\mathrm{M}+\mathrm{H}]^{+} 372.1571$, found 372.1568 .

\section{2-(Diethoxyphosphoryl)-N-(2-trifluoromethylbenzylidene)propan-2-amine oxide (2-CF $-P P N ; 4 p)$.}

The title compound was obtained from $3(300 \mathrm{mg}, 1.4 \mathrm{mmol})$ and 2-trifluoromethylbenzaldehyde (250 $\mathrm{mg}, 1.4 \mathrm{mmol})$ in $\mathrm{CH}_{2} \mathrm{Cl}_{2}(15 \mathrm{~mL})$ as a green oil $(0.33 \mathrm{~g}, 60 \%):{ }^{1} \mathrm{H} \mathrm{NMR}\left(300 \mathrm{MHz}, \mathrm{CDCl}_{3}\right) \delta 9.42(\mathrm{~d}, J$ $=8.1 \mathrm{~Hz}, 1 \mathrm{H}, \mathrm{H}-3), 7.80(\mathrm{~d}, J=2.5 \mathrm{~Hz}, 1 \mathrm{H}, H \mathrm{C}=\mathrm{NO}), 7.72(\mathrm{~d}, J=7.8 \mathrm{~Hz}, 1 \mathrm{H}, \mathrm{H}-6), 7.62(\mathrm{t}, J=7.7 \mathrm{~Hz}$, 1H, H-4), 7.47 (t, $J=7.7 \mathrm{~Hz}, 1 \mathrm{H}, \mathrm{H}-5), 4.20\left(\mathrm{~m}, 4 \mathrm{H}, 2 \times \mathrm{OCH}_{2} \mathrm{CH}_{3}\right), 1.88\left(\mathrm{~s}, 3 \mathrm{H}, \mathrm{C}\left(\mathrm{CH}_{3}\right)_{2}\right), 1.83(\mathrm{~s}$, $\left.3 \mathrm{H}, \mathrm{C}\left(\mathrm{CH}_{3}\right)_{2}\right), 1.34\left(\mathrm{t}, J=7.1 \mathrm{~Hz}, 6 \mathrm{H}, 2 \times \mathrm{OCH}_{2} \mathrm{CH}_{3}\right) ;{ }^{13} \mathrm{C} \mathrm{NMR}\left(75 \mathrm{MHz}, \mathrm{CDCl}_{3}\right) \delta 132.0(\mathrm{C}-5), 129.4$ (C-4), 129.0 (C-6), 127.9 (br s, C-1 and HC=NO), 127.4 (q, $J=29.7, \mathrm{C}-2$ ), 125.7 (q, $J=6.1 \mathrm{~Hz}, \mathrm{C}-3$ ),

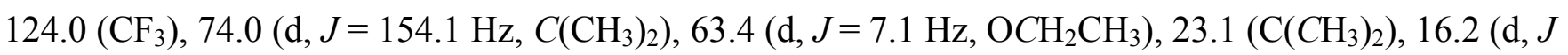
$\left.=5.5 \mathrm{~Hz}, \mathrm{OCH}_{2} \mathrm{CH}_{3}\right) ;{ }^{31} \mathrm{P} \mathrm{NMR}\left(121 \mathrm{MHz}, \mathrm{CDCl}_{3}\right) \delta$ 22.36. HRMS-ESI: calcd for $\mathrm{C}_{15} \mathrm{H}_{22} \mathrm{NO}_{4} \mathrm{PF}_{3}{ }^{+}$ $[\mathrm{M}+\mathrm{H}]^{+}$368.1233, found 368.1233.

2-(Diethoxyphosphoryl)-N-(2,6-dimethylbenzylidene)propan-2-amine oxide (2,6-Me-PPN; 4q). The title compound was obtained from $3(300 \mathrm{mg}, 1.4 \mathrm{mmol})$ and 2,6-dimethylbenzaldehyde (190 mg, 1.4 $\mathrm{mmol})$ in THF $(20 \mathrm{~mL})$ as a white precipitate from $\mathrm{Et}_{2} \mathrm{O}(0.15 \mathrm{~g}, 32 \%), \mathrm{mp} 66.7{ }^{\circ} \mathrm{C}:{ }^{1} \mathrm{H}$ NMR $(300$

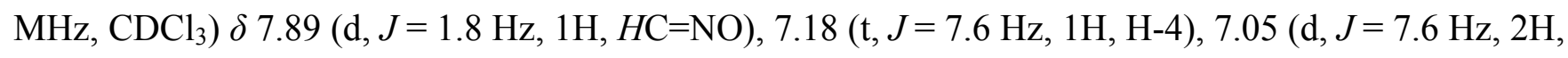
H-3); $4.24\left(\mathrm{~m}, 4 \mathrm{H}, \mathrm{P}\left(\mathrm{OCH}_{2} \mathrm{CH}_{3}\right)_{2}\right), 2.30\left(\mathrm{~s}, 6 \mathrm{H}, 2 \times \mathrm{CH}_{3}\right), 1.89\left(\mathrm{~s}, 3 \mathrm{H}, \mathrm{C}\left(\mathrm{CH}_{3}\right)_{2}\right), 1.84\left(\mathrm{~s}, 3 \mathrm{H}, \mathrm{C}(\mathrm{CH})_{2}\right)$, $1.36\left(\mathrm{t}, J=7.1 \mathrm{~Hz}, 6 \mathrm{H}, \mathrm{P}\left(\mathrm{OCH}_{2} \mathrm{CH}_{3}\right)_{2}\right) ;{ }^{13} \mathrm{C} \mathrm{NMR}\left(75 \mathrm{MHz}, \mathrm{CDCl}_{3}\right) \delta 137.6(\mathrm{~d}, J=1.5 \mathrm{~Hz}, \mathrm{C}-2), 133.4$ $(\mathrm{d}, J=5.5 \mathrm{~Hz}, \mathrm{HC}=\mathrm{NO}), 129.1(\mathrm{C}-4), 128.8(\mathrm{C}-1), 127.5(\mathrm{C}-3), 72.5\left(\mathrm{~d}, J=155.7 \mathrm{~Hz}, C\left(\mathrm{CH}_{3}\right)_{2}\right), 63.35$

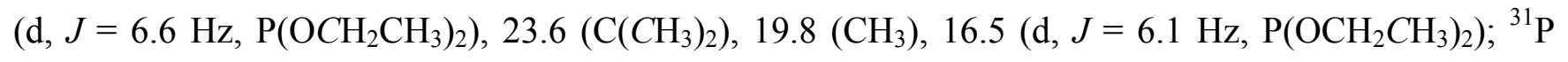


NMR (121.5 MHz, $\left.\mathrm{CDCl}_{3}\right) \delta$ 23.03. HRMS-ESI: calcd for $\mathrm{C}_{16} \mathrm{H}_{27} \mathrm{NO}_{4} \mathrm{P}^{+}[\mathrm{M}+\mathrm{H}]^{+} 328.1672$, found 328.1672.

2-(Diethoxyphosphoryl)-N-(4-chlorobenzylidene)propan-2-amine oxide (4-Cl-PPN; 4r). The title compound was obtained from 3 (300 mg, $1.4 \mathrm{mmol})$ and 4-chlorobenzaldehyde (199 mg, $1.4 \mathrm{mmol})$ in DCE $(15 \mathrm{~mL})$ as a white precipitate from pentane $/ \mathrm{Et}_{2} \mathrm{O}, 7: 3(0.35 \mathrm{~g}, 74 \%), \mathrm{mp} 79.2{ }^{\circ} \mathrm{C}\left(\right.$ litt. $\left.[48] 81{ }^{\circ} \mathrm{C}\right)$ : ${ }^{1} \mathrm{H}$ NMR $\left(300 \mathrm{MHz}, \mathrm{CDCl}_{3}\right) \delta 8.23(\mathrm{~d}, J=8.6 \mathrm{~Hz}, 2 \mathrm{H}, \mathrm{H}-2), 7.74(\mathrm{~d}, J=2.8 \mathrm{~Hz}, 1 \mathrm{H}, H \mathrm{C}=\mathrm{NO}), 7.37(\mathrm{~d}$, $J=8.6 \mathrm{~Hz}, 2 \mathrm{H}, \mathrm{H}-3), 4.20\left(\mathrm{~m}, 4 \mathrm{H}, 2 \times \mathrm{OCH}_{2} \mathrm{CH}_{3}\right), 1.86\left(\mathrm{~s}, 3 \mathrm{H}, \mathrm{C}\left(\mathrm{CH}_{3}\right)_{2}\right), 1.81\left(\mathrm{~s}, 3 \mathrm{H}, \mathrm{C}(\mathrm{CH})_{2}\right), 1.33(\mathrm{t}$, $\left.J=7.2 \mathrm{~Hz}, 6 \mathrm{H}, 2 \times \mathrm{OCH}_{2} \mathrm{CH}_{3}\right) ;{ }^{13} \mathrm{C} \mathrm{NMR}\left(75 \mathrm{MHz}, \mathrm{CDCl}_{3}\right) \delta 135.8(\mathrm{C}-4), 132.3(\mathrm{~d}, J=1.5 \mathrm{~Hz}, \mathrm{C}-1)$, $130.2(\mathrm{C}-2), 129.2(\mathrm{~d}, J=4.4 \mathrm{~Hz}, \mathrm{HC}=\mathrm{NO}), 128.7(\mathrm{C}-3), 73.0\left(\mathrm{~d}, J=154.1 \mathrm{~Hz}, C\left(\mathrm{CH}_{3}\right)_{2}\right), 63.5(\mathrm{~d}, J=$ $\left.6.6 \mathrm{~Hz}, \mathrm{OCH}_{2} \mathrm{CH}_{3}\right), 23.3\left(\mathrm{C}_{\left.\left(\mathrm{CH}_{3}\right)_{2}\right),} 16.4\left(\mathrm{~d}, J=5.5 \mathrm{~Hz}, \mathrm{OCH}_{2} \mathrm{CH}_{3}\right) ;{ }^{31} \mathrm{P} \mathrm{NMR}\left(121 \mathrm{MHz}, \mathrm{CDCl}_{3}\right) \delta\right.$ 22.92. HRMS-ESI: calcd for $\mathrm{C}_{14} \mathrm{H}_{22} \mathrm{NO}_{4} \mathrm{PCl}^{+}[\mathrm{M}+\mathrm{H}]^{+} 334.0970$, found 334.0971 .

X-ray Diffraction Analysis. X-ray crystal structures were collected at $293 \mathrm{~K}$ on a Bruker-Nonius Kappa CCD diffractometer using graphite-monochromated Mo K $\alpha$ radiation $(\lambda=0.71073 \AA)$.

Crystal data for 4b: $M=315.29$, space group C c, Hall group C -2yc, $a=11.5234(5) \AA, b=23.042(1)$ $\AA, c=7.7077(4) \AA, \alpha=90^{\circ}, \beta=127.607(2)^{\circ}, \gamma=90^{\circ}$.

Crystal data for [4f+4f'] dimer: $M=331.30$, space group P 21/c, Hall group -P 2ybc, $a=12.2694(14)$ $\AA, b=34.361(3) \AA, c=11.7456(12) \AA, \alpha=90^{\circ}, \beta=95.870(12)^{\circ}, \gamma=90^{\circ}$.

Crystal data for 4k: $M=344.30$, space group C c, Hall group C -2yc, $a=14.3666(4) \AA, b=$ 17.1483(4) $\AA, c=7.19842(16) \AA, \alpha=90^{\circ}, \beta=94.052(2)^{\circ}, \gamma=90^{\circ}$.

Crystal data for 4q: $M=327.35$, space group C c, Hall group C -2yc, $a=16.2402(9) \AA ⿻$, $b=$ 20.1187(2) $\AA, c=9.1254(5) \AA, \alpha=90^{\circ}, \beta=143.236(12)^{\circ}, \gamma=90^{\circ}$.

CCDC reference numbers 1423593 (4b), 1423601 (4f), 1423594 (4k) and 1423602 (4q) contain the supplementary crystallographic data for the X-ray studies reported in this study. This material can be obtained free of charge at www.ccdc.cam.uk/conts/retrieving.html or from the Cambridge 
Crystallographic Data Centre at deposit@ccdc.cam.ac.uk. This material is available free of charge via the Internet at http://pub.acs.org.

EPR Experiments. Chemicals and UV irradiations. All chemicals, enzymes and solvents were analytical grade from Sigma-Aldrich, including diethylenetriaminepentaacetic acid (DTPA), $\mathrm{H}_{2} \mathrm{O}_{2}$, $\mathrm{NaNO}_{2}, \mathrm{SNP}$ and the spin trap PBN. Diethyl(1-(tert-butylamino)-eth-1-yl)phosphonate (7; see Figure 5 inset) [69] and MGD [70] were synthesized according to reported procedures. 2-Nitroso propyl-2diethylphosphonate $\mathbf{6}$ was obtained by oxidation of aminophosphonate $\mathbf{1}$ by a modification of a reported procedure [71] (see Supporting Information).

Doubly distilled deionized water was used in all experiments and all buffer solutions were filtered through a $0.2-\mu \mathrm{m}$ Millipore filter prior to use. UV irradiations were carried out at $254 \mathrm{~nm}$ in a darkroom viewing cabinet using a 6-Watts VL-6.LC lamp (Fisher Biotec).

Formation of PPNs spin adducts and their EPR detection. In all spin trapping experiments, the initial PPNs concentration was set at 30-50 mM, giving saturated aqueous solutions for the least soluble nitrones. For spin-trapping $\mathrm{HO} \cdot$, a Fenton reagent was carried out, consisting of (final concentrations) $\mathrm{FeSO}_{4}(1 \mathrm{mM}), \mathrm{H}_{2} \mathrm{O}_{2}(3 \mathrm{mM})$ and the tested nitrone in $20 \mathrm{mM}$ phosphate buffer with the $\mathrm{pH}$ adjusted to 4.1-4.5. Alternatively, attempts to generate PPNs-OH were performed using either photolysis of 3\% $\mathrm{H}_{2} \mathrm{O}_{2}$ or nucleophilic addition of water in the presence of $\mathrm{FeCl}_{3}(1 \mathrm{mM})$. The PPNs adducts of $\cdot \mathrm{CH}_{3}$, $\cdot \mathrm{CH}_{2} \mathrm{OH}, \mathrm{CH}_{3} \cdot \mathrm{CHOH}, \mathrm{CO}_{2} \cdot{ }^{-}$and $\mathrm{N}_{3} \cdot$ were obtained in $20 \mathrm{mM}$ phosphate buffer ( $\mathrm{pH}$ 7.4) by running the Fenton reagent described above in the presence of the tested PPNs and the competitor $(0.05-0.2 \mathrm{M})$ DMSO, methanol, ethanol, sodium formate and sodium azide, respectively. $\mathrm{PPNs}_{-} \mathrm{SO}_{3} \mathrm{H}$ adducts were prepared by incubating the nitrone with a mixture of sodium sulfite $(20 \mathrm{mM})$ and $4 \mathrm{mM}$ of either potassium dichromate or potassium ferricyanide in DTPA $(1 \mathrm{mM})$-supplemented phosphate buffer $(20$ mM). PPNs-H adducts were prepared in water by aerial oxidation of the nitrone with $\sim 5 \mathrm{mg}$ of $\mathrm{NaBH}_{4}$. The methoxy radical adducts $\mathrm{PPNs}-\mathrm{OCH}_{3}$ were obtained by adding $\sim 1 \mathrm{mg}$ of $\mathrm{Pb}(\mathrm{OAc})_{4}$ to the solution of the parent nitrone $(0.05 \mathrm{M})$ in DMSO containing $25 \%$ methanol. PPNs-OOH adducts were obtained 
by nucleophilic addition of $3 \% \mathrm{H}_{2} \mathrm{O}_{2}$ in oxygenated pyridine and alternative attempts to obtain these nitroxides were performed using either the hypoxanthine $(0.4 \mathrm{mM}) /$ xanthine oxidase $(0.02-0.03$ units $/ \mathrm{mL}) \mathrm{O}_{2}{ }^{-}$generator in DTPA (1 mM)-supplemented phosphate buffer (pH 7.0) or UV-photolysis of $30 \% \mathrm{H}_{2} \mathrm{O}_{2}$ in water.

Samples were quickly introduced into calibrated $50-\mu \mathrm{L}$ glass capillaries and 4096-points EPR spectra were recorded at room temperature within $40 \mathrm{~s}$ following initiation of free radical formation using a Bruker ESP 300 spectrometer (Karlsruhe, Germany) operating at X-band $(9.79 \mathrm{GHz})$ with a $100 \mathrm{kHz}$ modulation frequency, a microwave power of $10 \mathrm{~mW}$ and other settings specified in the appropriate figure legends. The magnetic field strength and microwave frequency were measured with a Bruker ER 035M NMR gaussmeter and a Hewlett-Packard 5350B frequency counter, respectively.

NO Spin trapping. The following stock solutions were prepared daily in deionized water: MGD (0.4 $\mathrm{M}), \mathrm{FeSO}_{4}(80 \mathrm{mM})$, and ascorbic acid $(0.2 \mathrm{M})$. NO release was quantified in aqueous solutions of test compound submitted to UV photolysis using EPR detection of the [Fe(II)-MGD $2-\mathrm{NO}$ ] complex [37]. Briefly, in a glass tube containing $0.4 \mathrm{~mL}$ of $20 \mathrm{mM}$ test compound (i.e., PPNs, PBN or compounds 5 and 6) were added in the following order: $50 \mu \mathrm{L}$ ascH, $25 \mu \mathrm{L}$ MGD and $25 \mu \mathrm{L} \mathrm{FeSO}_{4}$ as to reach the final concentrations of $20 \mathrm{mM}, 20 \mathrm{mM}$ and $4 \mathrm{mM}$ for ascH, MGD and $\mathrm{FeSO}_{4}$, respectively. The $\mathrm{pH}$ of the solution was measured, the mixture was placed into a standard $10 \mathrm{~mm}$ quartz flat cell and submitted to UV photolysis for 70 min following addition of Fe(II). Unless indicated otherwise, EPR spectra of the $\left[\mathrm{Fe}^{2+}-\mathrm{MGD}_{2}-\mathrm{NO}\right]$ complex were acquired by signal-averaging 10 scans using the following parameters: microwave power, $10 \mathrm{~mW}$; modulation frequency, $100 \mathrm{kHz}$; modulation amplitude, $0.198 \mathrm{mT}$; time constant, $163.84 \mathrm{~ms}$; receiver gain, $1 \times 10^{5}$; scan rate, $0.48 \mathrm{mT} / \mathrm{s}$ for a sweep width of $20 \mathrm{mT}$. Following EPR acquisition, the final $\mathrm{pH}$ of the solution was taken. In this assay, the known $\mathrm{NO}$ donors $\mathrm{NaNO}_{2}(20$ $\mathrm{mM})$ and SNP $(0.1 \mathrm{mM})$ were used as references. NO release was estimated from experiments in triplicate by double integration of computer-simulated $\left[\mathrm{Fe}^{2+}-\mathrm{MGD}_{2}-\mathrm{NO}\right] \mathrm{EPR}$ signals, with concentrations expressed in arbitrary units (au). 
Spin trapping in aortic rings and stability of frozen $\mathrm{PPNs}_{-} \mathrm{CH}_{3}$ spin adduct solutions. Frozen samples collected in the aortic rings preparations (see below) were sequentially thawed $(<1 \mathrm{~min})$, placed into a glass capillaries and their spin adduct content was measured by EPR $45 \mathrm{~s}$ after thawing of the sample using the instrument settings as indicated above, except: modulation amplitude, $0.07 \mathrm{mT}$; time constant $81.92 \mathrm{~ms}$; receiver gain, $8 \times 10^{4}$; scan rate, $0.31 \mathrm{mT} / \mathrm{s}$ for a sweep width of $13 \mathrm{mT}$; number of accumulated scans, 10 .

To check whether frozen storage of selected $\mathrm{PPNs}-\mathrm{CH}_{3}$ adducts may alter their EPR signal intensity, they were produced from $35 \mathrm{mM}$ PPN or nitrones $\mathbf{4 b}, \mathbf{d}, \mathbf{e}, \mathbf{g}-\mathbf{i}$ (sample volume, $1 \mathrm{~mL}$ ) in phosphate buffer solution ( $\mathrm{pH}$ 7.4) using the Fenton/DMSO generator described above. Prior to immediate storage in liquid nitrogen, a $\sim 0.35 \mathrm{~mL}$ aliquot was placed in a capillary tube and a control EPR spectrum was recorded 5 min following $\mathrm{Fe}^{2+}$ addition. Four days following freezing, the samples were successively thawed and EPR-scanned 1 min following complete thawing of the sample. Instrument settings were as indicated above, except: modulation amplitude, $0.063 \mathrm{mT}$; time constant $20.48 \mathrm{~ms}$; receiver gain, $2 \times$ $10^{5}$; scan rate, $0.15 \mathrm{mT} / \mathrm{s}$ for a sweep width of $13 \mathrm{mT}$; number of accumulated scans, 2.

Throughout, determination of hfscs of spin adducts and quantitative estimations were performed using spectral simulations obtained by the program of Rockenbauer and Korecz [72].

Animal Procedures. Ethics. All animal care and experimental procedures were performed according to the guidelines of the Directive 2010/63/EU of the European Parliament. The protocol was approved by the National Research Committee for the projects ANR CES 2008-INTOX (2008-2012) and FEDER-AdiabaOx (2008, $\left.\mathrm{n}^{\circ} 13851\right)$. The CNRS and Aix Marseille University have currently valid licences for animal housing and experimentation (agreement C13-055-06) delivered by the French Government and the study was under the supervision of a DVM at CNRS (agreement $\mathrm{N}^{\circ} 13-122$ ). The following authors M. Ca., E. R. and S. P. are graduated for the Certificate in Small Animal Surgery and Experimentation (Aix-Marseille Université, Faculté de Pharmacie and Centre de Formation Permanente du CNRS DR12, Marseille). 
Animals. Twelve male Sprague-Dawley rats weighing 200-250 g (CERJ, Le Genest St Isle, France) were used for the experiments. Animals were maintained in the local animal house under conventional conditions including an enrichment of the structural and social environment while promoting physical and cognitive activity, in a room with controlled temperature $\left(22 \pm 3{ }^{\circ} \mathrm{C}\right)$ and a reverse $12 \mathrm{~h} \mathrm{light} / \mathrm{dark}$ cycle with food (standard Teklad 2016 diet, Harlan Laboratories, Gannat, France) and water available ad libitum.

Isolated aortic rings preparation and treatments. Rats were deeply anesthetized by intraperitoneal injection of sodium pentobarbital (100 mg/kg; Ceva Santé Animale, Libourne, France) before thoracotomy. The aortas were excised, cleaned, dissected into 3-mm ring segments, mounted between two stainless steel hooks and suspended at $37{ }^{\circ} \mathrm{C}$ in oxygenated, isolated $10 \mathrm{~mL}$ baths filled with a modified Krebs-Henseleit $(\mathrm{KH})$ buffer $(\mathrm{pH} 7.35)$ containing (in $\mathrm{mM}$ ): $\mathrm{NaCl}, 118 ; \mathrm{KCl}, 4.7 ; \mathrm{KH}_{2} \mathrm{PO}_{4}$, 1.5; $\mathrm{CaCl}_{2}, 2.5 ; \mathrm{MgSO}_{4}, 1.2 ; \mathrm{NaHCO}_{3}, 25 ;$ EDTA, $0.5 ;$ glucose, 11 . The medium was renewed every 20 min and continuously aerated with a $5 \% \mathrm{CO}_{2}-95 \% \mathrm{O}_{2}$ gas mixture. Changes in tension were recorded using a standard apparatus (Harvard Apparatus, Les Ulis, France). Rings were first equilibrated for 60 min at $1 g$ of resting tension and then stretched step by step until optimal and reproducible reference contraction to high-potassium physiological salt solution (KPSS, $123 \mathrm{mM} \mathrm{KCl}$ ) was obtained. After a 20-min washout, rings were contracted to $50 \%$ of the KPSS response by $10^{-7} \mathrm{M}$ L-phenylephrine hydrochloride (Sigma-Aldrich) and endothelial integrity was tested by adding $10^{-5} \mathrm{M}$ ACh perchlorate (Sigma-Aldrich) to the medium. The endothelium was considered intact if ACh induced a relaxation of $80 \%$ or higher and the rings fulfilling this condition were reequilibrated for $30 \mathrm{~min}$ in $\mathrm{KH}$ buffer before the experiments.

In a first set of experiments, we evaluated the effect of PPNs $(200 \mu \mathrm{M})$ vs vehicle $[\mathrm{KH}+0.1 \%$ DMSO] on the sensitivity of rings to SNP-induced relaxation. The cumulative concentration-response curve to SNP $\left(10^{-10}-10^{-4} \mathrm{M}\right)$ was determined in stretched rings placed in individual wells and preconstricted to $67-70 \%$ of the reference response by PE $\left(5 \times 10^{-6} \mathrm{M}\right)$. Relaxation responses to SNP 
were expressed as percentage of PE induced precontraction. Data are means of 3-6 independent experiments.

In a second set of experiments, we used a reported procedure [58] to investigate whether pretreating rings by PPNs could protect against oxidative stress-induced impairment of ACh-induced vasorelaxation. Rings in wells containing $0.3 \mathrm{~mL}$ of [ $\mathrm{KH}$ buffer $+0.1 \% \mathrm{DMSO}]$ were incubated for 20 min at $37{ }^{\circ} \mathrm{C}$ in the presence of a mixture of xanthine oxidase $(10 \mathrm{mU} / \mathrm{mL}, 4 \mu \mathrm{L})$ and selected nitrones $(200 \mu \mathrm{M})$. Generation of $\mathrm{O}_{2}{ }^{-}-$was then triggerred by adding aqueous xanthine $(0.1 \mathrm{mM}, 10 \mu \mathrm{L})$ to the incubation medium. After 10 min exposure to ROS, rings were preconstricted to $60 \%$ of the reference response with $\mathrm{PE}\left(\sim 10^{-6} \mathrm{M}\right)$ and dose-response curves for the vasorelaxing activity to cumulative ACh concentrations $\left(10^{-9}-10^{-4} \mathrm{M}\right)$ were established and compared to that obtained in normal incubation conditions. Relaxation responses to ACh were expressed as percentage of PE induced precontraction. Data are means of 6 independent experiments/group.

In a third set of experiments, we examined the protection afforded by PPNs against tissue damage caused by endogenous $\mathrm{O}_{2}{ }^{-}$release as a result of NADPH stimulation of endothelial NADPH oxidase. Rings were first preincubated for $30 \mathrm{~min}$ in $[\mathrm{KH}$ buffer $+0.1 \% \mathrm{DMSO}$ containing the selected PPNs $(200 \mu \mathrm{M})$ and $30 \mu \mathrm{M}$ DTC (Sigma-Aldrich), then NADPH (1 mM) was added and incubation was prolonged up to $60 \mathrm{~min}$. Two equal sets of individual rings were then transferred into separate wells prefilled with $0.3 \mathrm{~mL}$ of the same $\mathrm{KH}$ buffer/PPNs or vehicle/NADPH mixture as described above, and further incubated for $30 \mathrm{~min}$ in the dark at $37{ }^{\circ} \mathrm{C}$. One subset of rings was kept for tissue protein carbonyls measurements and the other subset was used for EPR experiments (see below). Data were compared to control wells in which NADPH was omitted. In additional experiments, NADPH oxidase was inhibited by adding DPI (15 $\mu \mathrm{M}$; Sigma-Aldrich) to the medium during the 30 min preincubation phase.

Assay of proteins carbonyls. Protein carbonyls content was determined in ring tissues homogenates using the probe 7-hydrazino-4-nitrobenzo-2,1,3-oxadiazole (NBDH, Sigma-Aldrich) which forms highly fluorescent derivatives with several aldehydes via hydrazone formation [62]. Homogenates were 
prepared by quickly homogenizing $0.1 \mathrm{~g}$ of fresh aortic tissue powdered in liquid $\mathrm{N}_{2}$ in nine bulks of a $1.15 \% \mathrm{KCl}$ ice-cold solution. After centrifugation $\left(3000 \times \mathrm{g}\right.$ for $40 \mathrm{~min}$ at $\left.2-3{ }^{\circ} \mathrm{C}\right)$, the supernatants were diluted 10-fold with PBS $0.1 \mathrm{X}$. Protein concentrations were determined using the BCA assay kit (Thermo Fisher Scientific). Protein carbonyls were derivatized with NBDH in 96-well microplates and were measured in the homogenates by fluorimetry (TECAN Infinite 200), with excitation at $500 \mathrm{~nm}$ and emission recorded at $560 \mathrm{~nm}$. Protein carbonyls content are expressed in nanomoles/mg protein and are the means of 6-12 experiments/group made in triplicate and oxidized BSA was used for calibration.

Preparation of samples for EPR analysis. To each well containing NADPH-stimulated rings in $\mathrm{KH}$ buffer for EPR experiments was added an aliquot of the selected PPNs in DMSO as to reach a final concentration of $15 \mathrm{mM}$ nitrone and $1 \% \mathrm{DMSO}$, and the mixture was incubated for 20 additional min. For each tested PPNs, three $300 \mu \mathrm{L}$-aliquots of the mixture were placed in cryotubes and immediately stored in liquid nitrogen for delayed EPR analysis (see above).

Data calculations and Statistics. Most results were obtained by constructing sigmoidal $\log$ concentration-response curves (Prism 5.0 software, GraphPad, San Diego, CA). Data are expressed as mean \pm SD or SEM for the indicated number of independent experiments. Differences were analyzed using a one-way analysis of variance (ANOVA) followed by a posteriori Newman-Keuls test. Intergroup differences were considered to be significant at $P<0.05$.

\section{Acknowledgments}

The study was supported by grants from the MENRT (2012-2015) and the Agence Nationale pour la Recherche (ANR CES 2008-INTOX-Partner 2). The authors thank H. Rahmouni, V. Pique and P. Stocker for their helpful assistance during experiments, M. Mekaouche (CNRS, CHU Hôpital Nord, Marseille), for his expertise in animal care and preparation, D. M. Bailey and B. Tuccio-Lauricella for

discussion. C. K. gratefully acknowledges the Ministère Algérien de l'Enseignement et de la Recherche for grants (P.N.E. 2014-2016). 


\section{Associated content}

\section{Supporting Information}

Synthesis and analytical data of nitroso compound 6. Additional Figure S1 illustrating X-ray structure of nitrones $\mathbf{4 f}$ and $\mathbf{4 k}$, including packing in the crystal lattice of [4f-4f'] dimers. Additional Figure S2 showing the EPR spectrum of benzoyl nitroxide 4-OH-3,5-OMe-PPNsOX radical formed from nitrone 4i. Procedures for antioxidant assays. Cell culture procedures and cytotoxicity assays.

\section{$\underline{\text { FIGURE CAPTIONS }}$}

Figure 1. Structures of (A) PBN and its antioxidant-based derivatives BHT-PBN [21] and Trolox-PBN [22] successfully tested in in vitro and animal models of oxidative stress, and (B) phenolic (4a-4i) and non phenolic $(\mathbf{4 j} \mathbf{j} \mathbf{4 q})$ derivatives of PPN $(\mathrm{R}=\mathrm{H})$. All PPNs are newly described except for compounds 4c [32], $4 \mathbf{l}$ [30] and 4r [29], and the following nitrones bear aromatic rings inspired from the phenolic acids: caffeic acid (4d), gallic acid (4g), ferulic acid (4h) and sinapic acid (4i).

Figure 2. ORTEP view, drawn with 50\% probability ellipsoids, showing atom numbering of (A) 3-OHPPN (4b) and (B) 2,6-Me-PPN (4q). The N(8)-O(9) bond of nitrone function is oriented towards the rear. Dashed lines indicate intramolecular H-bonds. Free radical addition occurs at C(1) (encircled).

Figure 3. X-band $(9.79 \mathrm{GHz})$ EPR spectra at room temperature and associated computer simulations of (A) 2- $\mathrm{CF}_{3}-\mathrm{PPN}-\mathrm{SO}_{3} \mathrm{H}$; (B) 4-OH-3,5-OMe-PPN-SO $3 \mathrm{H}$; (C) 4- $\mathrm{CO}_{2} \mathrm{H}-\mathrm{PPN}-\mathrm{OOH}$ and (D) 4-OH-3-OMePPN-OCH 3 . Spectra were obtained in phosphate buffer ( $\mathrm{pH} 7.4$; traces $\mathrm{A}-\mathrm{C}$ ) or DMSO/methanol (75:25; trace D) at $10 \mathrm{~mW}$ microwave power and $100 \mathrm{kHz}$ modulation frequency using the parameters (for spectra A-D): modulation amplitude 0.011, 0.035, 0.063, $0.035 \mathrm{mT}$; time constant, 40.96, 40.96, 
40.96, $81.92 \mathrm{~ms}$; receiver gain, 4, 8, 6.3, $3.2 \times 10^{5}$; sweep rate, $0.24,0.21,0.12,0.15 \mathrm{mT} / \mathrm{s}$; number of accumulated scans, 5, 5, 4, 2 .

Figure 4. $\left[\mathrm{Fe}(\mathrm{II})-\mathrm{MGD}_{2}-\mathrm{NO}\right]$ formation from aqueous PPNs UV-photolyzed for 70 min in the presence of ascorbic acid $(20 \mathrm{mM}), \mathrm{MGD}(20 \mathrm{mM})$ and $\mathrm{FeSO}_{4}(4 \mathrm{mM})$. (A) Room temperature EPR spectrum recorded from saturated aqueous 4-Cl-PPN 4r and simulation consistent with a mixture of 44\% nitrosyliron complex (low-field triplet) and decomposition signals consisting of an alkyl radical adduct (as a 12lines spectrum) and a triplet (•) which account for $35 \%$ and $21 \%$ of the total signal, respectively. EPR settings: microwave power, $20 \mathrm{~mW}$, modulation amplitude, $0.056 \mathrm{mT}$; receiver gain, $4 \times 10^{4}$; time constant, $40.96 \mathrm{~ms}$; sweep time for each scan, $0.24 \mathrm{mT} / \mathrm{s}$ for a sweep width of $20 \mathrm{mT}$; number of accumulated scans, 2. (B) Mean $\pm \mathrm{SD}$ formation of $\left[\mathrm{Fe}(\mathrm{II})-\mathrm{MGD}_{2}-\mathrm{NO}\right]$ from nitrones $(20 \mathrm{mM})$ and optimized $\mathrm{C}(1)-\mathrm{N}(8)$ bond lengths of the corresponding hydroxylamine 5 calculated using HyperChem 8.0 Pro. Black bars indicate compounds with ortho aryl substitution. One-way ANOVA $(P<0.01)$ followed by Newman-Keuls test: ${ }^{*} P<0.01$ vs PPN $(n=3)$.

Figure 5. Mechanism of light-induced NO release by PPNs in aqueous medium. Inset: chemical structure of aminophosphonate 7 which does not release NO in aqueous solution.

Figure 6. (A) Effect of PPNs $(200 \mu \mathrm{M})$ on the responses to ACh following treatment with xanthine $(0.1$ $\mathrm{mM}) / x a n t h i n e$ oxidase $(10 \mathrm{mU} / \mathrm{mL})$. Data are means \pm SEM of 3-6 experiments/group. Two-way ANOVA followed by Newman-Keuls test: ${ }^{+} P<0.05$ vs xanthine/xanthine oxidase group. (B) Tissue protein carbonyls following exposure to NADPH $(1 \mathrm{mM})$ for $60 \mathrm{~min}$ in the presence of PPNs. Data are means \pm SEM of 9-12 experiments/group. One-way ANOVA $(P<0.01)$ followed by Newman-Keuls test: ${ }^{*} P<0.05,{ }^{* *} P<0.01$ and ${ }^{* * *} P<0.001$ vs vehicle; ${ }^{\S} P<0.01$ vs $P P N$ group. 
Figure 7. Indirect spin trapping evidence for hydroxyl radical formation in the supernatant of rat aortic rings stimulated by NADPH $(1 \mathrm{mM})$ for $80 \mathrm{~min}$. After $60 \mathrm{~min}$ NADPH stimulation in $\mathrm{KH}$ buffer, the spin trap (15 mM) diluted in DMSO (1\% final concentration) was added to the medium and incubated with rings for 20 min. (A) EPR signal recorded in (a) the complete incubation system containing NADPH, DMSO, DTC (30 $\mu \mathrm{M})$ and 3-OH-PPN 4b. Simulation was consistent with a mixture of 3-OHPPN-CH 3 (94\%; see hfscs in Table 2) and a decomposition signal (6\%) with hfscs: $\mathrm{a}_{\mathrm{N}}=1.399$; $\mathrm{a}_{\mathrm{P}}=$ $3.825 \mathrm{mT}$; (b) complete incubation system minus NADPH; (c) complete incubation system in the presence of DPI $(15 \mu \mathrm{M})$. (B) Mean \pm SD of methyl radical spin adduct EPR intensity. One-way ANOVA $(P<0.01)$ followed by Newman-Keuls test: $* P<0.01$ vs PPN $(n=3)$. EPR settings: microwave power, $10 \mathrm{~mW}$, modulation amplitude, $0.07 \mathrm{mT}$; receiver gain, $8 \times 10^{4}$; time constant, 81.92 ms; sweep time for each scan, $0.31 \mathrm{mT} / \mathrm{s}$ for a sweep width of $13 \mathrm{mT}$; number of accumulated scans, 10.

\section{Abbreviations used}

PBN, $\alpha$-phenyl- $N$-tert-butylnitrone; PBNs, PBN-type nitrones; PPN, 2-(Diethoxyphosphoryl)- $N$ (benzylidene)propan-2-amine oxide; PPNs, aryl substituted PPN-type nitrones; ROS, reactive oxygen species; STW, spectrum total width; MGD, $N$-methyl- $D$-glucamide dithiocarbamate; DTPA, diethylenetriaminepentaacetic acid; SNP, sodium nitroprusside; KH, Krebs-Henseleit; KPSS, highpotassium physiological salt solution; ACh, acetylcholine; PE, L-phenylephrine hydrochloride; DMEM, Dulbecco's modified Eagle's medium; DPI, diphenylene iodonium, DTC, diethyldithiocarbamate.

\section{References}

[1] Halliwell, B.; Gutteridge, J. M. C. In Free Radicals in Biology and Medecine, 4th ed.; Oxford University Press: Oxford, 2007.

[2] Sies, H. Oxidative stress: a concept in redox biology and medicine. Redox Biol. 2015, 4, 180183. 
[3] Jones, D.P. Redefining oxidative stress. Antioxid. Redox Signal. 2006, 8, 1865-1879.

[4] Jones, D. P.; Sies, H. The redox code. Antioxid. Redox Signal. 2015, 23, 734-746.

[5] Espinoza-Diez, C.; Miguel, V.; Mennerich, D.; Kietzmann, T.; Sanchez-Perez, P.; Cadenas, S.; Lamas, S. Antioxidant responses and cellular adjustments to oxidative stress. Redox Biol. 2015, 6, 183197.

[6] Murphy, M. P. Antioxidants as therapies: can we improve on nature? Free Radic. Biol. Med. 2014, 66, 20-23.

[7] Thomas, C. E. Approaches and Rationale for the Design of Synthetic Antioxidants as Therapeutic Agents. In Handbook of Synthetic Antioxidants; Packer, L., Cadenas, E., Eds.; Marcel Dekker: New York, 1997; pp 1-52.

[8] Cadenas, E. Basic mechanisms of antioxidant activity. Biofactors 1997, 6, 391-397.

[9] Niki, E.; Yoshida, Y.; Saito, Y.; Noguchi, N. Lipid peroxidation: mechanism, inhibition, and biological effects. Biochem. Biophys. Res. Commun. 2005, 338, 668-676.

[10] Ingold, K. U.; Pratt, D. A. Advances in radical trapping antioxidant chemistry in the 21 st century: a kinetics and mechanisms perspective. Chem. Rev. 2014, 114, 9022-9046.

[11] Villamena, F. A.; Zweier, J. Detection of reactive oxygen and nitrogen species by EPR spin trapping. Antioxid. Redox Signal. 2004, 6, 619-629.

[12] Novelli, G. P.; Angiolini, P.; Tani, R.; Consales, G.; Bordi, L. Phenyl-t-butyl nitrone is active against traumatic shock in rats. Free Radic. Res. Commun. 1986, 1, 321-327.

[13] Floyd, R. A; Kopke, R. D.; Choi, C. H.; Foster, S. B.; Doblas, S., Towner, R. A. Nitrones as therapeutics. Free Radic. Biol. Med. 2008, 45, 1361-1374. 
[14] Kotake, Y.; Sang, H.; Miyajima, T. Wallis, G. L. Inhibition of NF-кB, iNOS mRNA, COX2 mRNA, and COX catalytic activity by phenyl-N-tert-butylnitrone (PBN). Biochim. Biophys. Acta 1998, $1448,77-84$.

[15] Das, A.; Gopalakrishnan, B.; Voss, O. H.; Doseff, A. I.; Villamena, F. A. Inhibition of ROSinduced apoptosis in endothelial cells by nitrone spin traps via induction of phase II enzymes and suppression of mitochondria-dependent pro-apoptotic signaling. Biochem. Pharmacol. 2012, 84, 486497.

[16] Yasui, H.; Ito, N.; Yamamori, T.; Nakamura, H.; Okano, J.; Asanuma,T.; Nakajima, T.; Kuwabara, M.; Inanami, O. Induction of neurite outgrowth by $\alpha$-phenyl- $N$-tert-butylnitrone through nitric oxide release and Ras-ERK pathway in PC12 cells. Free Radic. Res. 2010, 44, 645-654.

[17] Chamulitrat, W.; Jordan, S. J.; Mason, R. P.; Saito, K.; Cutler, R. G. Nitric oxide formation during light-induced decomposition of phenyl N-tert-butyl nitrone. J. Biol. Chem. 1993, 268, 1152011527.

[18] Cui, Z. G.; Kondo, T.; Matsumoto, H. Enhancement of apoptosis by nitric oxide released from ג-phenyl-tert-butyl nitrone under hyperthermic conditions. J. Cell. Physiol. 2006, 206, 468-476.

[19] Choteau, F.; Durand, G.; Ranchon-Cole, I.; Cercy, C.; Pucci, B. Cholesterol-based a-phenyl-Ntert-butyl nitrone derivatives as antioxidants against light-induced retinal degeneration. Bioorg. Med. Chem. 2010, 20, 7405-7409.

[20] Sambasiva Rao, P.; Kurumurthy, C.; Veeraswamy, B.; Santhosh Kumar, G.; Poornachandra, Y.; Ganesh Kumar, C.; Sathish Babu Vasamsetti ; Srigiridhar Kotamraju. Synthesis of novel 1,2,3triazole substituted-N-alkyl/aryl nitrone derivatives, their inflammatory and anticancer activity. Eur. J. Med. Chem. 2014, 80, 184-191. 
[21] Barclay, L R. C.; Vinqvist, M. R. Do spin traps also act as classical chain-breaking antioxidants? A quantitative kinetic study of phenyl tert-butylnitrone $(\mathrm{PBN})$ in solution and in liposomes. Free Radic. Biol. Med. 2000, 28, 1079-1090.

[22] Balogh, G. T.; Vukics, K.; Könczöl, A.; Kis-Varga, A.; Gere, A.; Fisher, J. Nitrone derivatives of trolox as neuroprotective agents. Bioorg. Med. Chem. Lett. 2005, 15, 3012-3015.

[23] Kim, S.; de A. Vilela, G. V. M.; Bouajila, J.; Dias, A. G.; Cyrino, F. Z. G. A.; Bouskela, E.; Costa, P. R. R.; Nepveu, F. Alpha-phenyl-N-tert-butyl nitrone (PBN) derivatives: synthesis and protective action against microvascular damages induced by ischemia/reperfusion. Bioorg. Med. Chem. 2007, 15, 3572-3578.

[24] Chavarria, C.; Perez, D. I.; Pérez, C.; Morales-Garcia, J. A.; Alonso-Gil, S.; Pérez-Castillo, A.; Gil, C.; Souza, J. M., Porcal, W. Microwave-assisted synthesis of hydroxyphenyl nitrones with protective action against oxidative stress. Eur. J. Med. Chem. 2012, 58, 44-49.

[25] Rice-Evans, C. A.; Miller, N. J.; Paganga, G. Structure-antioxidant activity relationships of flavonoids and phenolic acids. Free Radic. Biol. Med. 1996, 20, 933-946.

[26] Del Rio, D.; Rodriguez-Mateos, A.; Spencer, J. P. E.; Tognolini, M.; Borges, G.; Crozier, A. Dietary (poly)phenolics in human health: structures, bioavailability, and evidence of protective effects against chronic deseases. Antioxid. Redox Signal. 2013, 18, 1818-1892.

[27] Maurelli, E.; Culcasi, M.; Delmas-Beauvieux, M. C.; Miollan, M.; Gallis, J. L.; Tron, T.; Pietri, S. New perspectives on the cardioprotective phosphonate effect of the spin trap 5-(diethoxyphosphoryl)5-methyl-1-pyrroline N-oxide: an hemodynamic ${ }^{31} \mathrm{P}$ NMR study in rat hearts. Free Radic. Biol. Med. 1999, 27, 34-41.

[28] Culcasi, M.; Casano, G.; Lucchesi, C.; Mercier, A.; Clément, J. L.; Pique, V.; Michelet, L.; Krieger-Liszkay, A.; Robin, M.; Pietri, S. Synthesis and biological characterization of new 
aminophosphonates for mitochondrial $\mathrm{pH}$ determination by ${ }^{31} \mathrm{P}$ NMR spectroscop. J. Med. Chem. 2013, $56,2487-2499$.

[29] Tuccio, B.; Zeghdaoui, A.; Finet, J. P.; Cerri, V.; Tordo, P. Use of new $\beta$-phosphorylated nitrones for the spin trapping of free radicals. Res. Chem. Intermed. 1996, 4, 393-404.

[30] Rizzi, C.; Marque, S.; Belin, F.; Bouteiller, J. C.; Lauricella, R.; Tuccio, B.; Cerri, V.; Tordo, P. PPN-type nitrones: preparation and use of a new series of $\beta$-phosphorylated spin-trapping agents. $J$. Chem. Soc., Perkin Trans. 2 1997, 17, 2513-2518.

[31] Farrugia, L. J. WinGX and ORTEP for Windows: an update. J. Appl. Crystallogr. 2012, 45, 849-854.

[32] Liu, Y. P.; Wang, L. F.; Nie, Z.; Ji, Y. Q.; Liu, Y.; Liu, K. J.; Tian, Q. Effect of the phosphoryl substituent in the linear nitrone on the spin trapping of superoxide radical and the stability of the superoxide adduct: combined experimental and theoretical studies. J. Org. Chem. 2006, 71, 7753-7762.

[33] Janzen, E. G.; DuBose, C. M.; Kotake, Y. 2,4,6-trimethoxyphenyl tert-butyl nitrone $(\mathrm{MO})_{3} \mathrm{PBN}$, as a detector of hydroxyl radicals in the presence of peroxides, superoxide and peroxyl radicals. Tetrahedron Lett. 1990, 31, 7395-7398.

[34] Rizzi, C.; Lauricella, R.; Bouteiller, J. C.; Roubaud, V.; Tuccio, B. Distribution of the methyl radical adduct of $\mathrm{N}$-benzylidene-1-diethoxyphosphoryl-1-methylethylamine $\mathrm{N}$-oxide-type nitrones in water-sodium dodecyl sulfate micelles: an electron paramagnetic resonance spin trapping study. Magn. Reson. Chem. 2002, 40, 273-278.

[35] Janzen, E. G.; Kotake, Y.; Hinton, R. D. Stabilities of hydroxyl radical spin adducts of PBNtype spin traps. Free Radic. Biol. Med. 1992, 12, 169-173.

[36] Pacifici, J. G.; Browning, H. L. Jr. $\alpha$-(3,5-Di-tert-butyl-4-hydroxyphenyl)-N-tert-butylnitrone. A novel probe for radical detection and identification. J. Am. Chem. Soc. 1970, 92, 5231-5233. 
[37] Saito, K.; Ariga, T.; Yoshioka, H. Generation of nitric oxide from spin-trapping agents under oxidative conditions. Biosci. Biotechnol. Biochem. 1998, 62, 275-279.

[38] Locigno, E. J.; Zweier, J. L.; Villamena, F. A. Nitric oxide release from the unimolecular decomposition of the superoxide radical anion adduct of cyclic nitrones in aqueous medium. Org. Biomol. Chem. 2005, 3, 3220-3227.

[39] Villamena, F. A.; Hadad, C. M.; Zweier, J. L. Theoretical study of the spin trapping of hydroxyl radical by cyclic nitrones: a density functional theory approach. J. Am. Chem. Soc. 2004, 126, 18161829.

[40] Du, L. B.; Wang, L. F.; Liu, Y. P.; Jia, H. Y.; Liu, Y.; Liu, K. J.; Tian, Q. Effect of 2, 5substituents on the stability of cyclic nitrone spin adducts: a density functional theory approach. Free Radic. Res. 2010, 44, 751-762.

[41] Huang, D.; Ou, B.; Prior, P. L. The chemistry behind antioxidant capacity assays. J. Agric. Food Chem. 2005, 53, 1841-1856.

[42] Dresch, M. T.; Rossato, S. B.; Kappel, V. D.; Biegelmeyer, R.; Hoff, M. L.; Mayorga, P.; Zuanazzi, J. A.; Henriques, A. T.; Moreira, J. C. Optimization and validation of an alternative method to evaluate total reactive antioxidant potential. Ann. Biochem. 2009, 385, 107-114.

[43] Stoica, B.A.; Bordeianu, G.; Stanescu, R.; Serban, D.N.; Nechifor, M. A new method for the quantification of superoxide dismutase mimics with an allopurinol-xanthine oxidase-lucigenin enhanced system. J. Biol. Inorg. Chem. 2011, 16, 753-761.

[44] Foti, M. C. Use and abuse of the DPPH radical. J. Agric. Food Chem. 2015, 63, 8765-8776.

[45] Amorati, R.; Pedulli, G. F.; Cabrini, L.; Zambonin, L.; Landi, L. Solvent and pH effects on the antioxidant activity of caffeic and other phenolic acids. J. Agric. Food Chem. 2006, 54, 2932-2937. 

ferulic acid and its related compounds. J. Agric. Food Chem. 2002, 50, 2161-2168.

[47] Samadi, A.; Soriano, E.; Revuelta, J.; Valderas, C.; Chioua, M.; Garrido, I.; Bartolomé, B.; Tomassolli, I.; Ismaili, L.; Gonzalez-Lafuente, L.; Villaroya, M.; Garcia, A.G.; Oset-Gasque, M.J.; Marco-Contelles, J. Synthesis, structure, theoretical and experimental in vitro antioxidant/pharmacological properties of $\alpha$-aryl, $N$-alkyl-nitrones, as potential agents for the treatment of cerebral ischemia. Bioorg. Med. Chem. 2011, 19, 951-960.

[48] Roubaud, V.; Lauricella, R.; Tuccio, B.; Bouteiller, J. C.; Tordo, P. Decay of superoxide spin adducts of new PBN-type phosphorylated nitrones. Res. Chem. Intermed. 1996, 22, 405-416.

[49] Cos, P.; Ying, L.; Calomme, M.; Hu, J. P.; Cimanga, K.; Van Poel, B.; Pieters, L.; Vlietinck, A. J.; Vanden Berghe, D. Structure-activity relationship and classification of flavonoids as inhibitors of xanthine oxidase and superoxide scavengers. J. Nat. Prod. 1998, 61, 71-76.

[50] Masuda, T.; Shingai, Y.; Takahashi, C.; Inai, M.; Miura, Y.; Honda, S.; Masuda, A. Identification of a potent xanthine oxidase inhibitor from oxidation of caffeic acid. Free Radic. Biol. Med. 2014, 69, 300-307.

[51] Haseloff, R. F.; Mertsch, K.; Rohde, E.; Baeger, I.; Grigor'ev, G.; Blasig, I. E. Cytotoxicity of spin trapping compounds. FEBS Lett. 1997, 418, 73-75.

[52] Gosset, G.; Clément, J. L.; Culcasi, M.; Rockenbauer, A.; Pietri, S. CyDEPMPOs: A class of stable cyclic DEPMPO derivatives with improved properties as mechanistic markers of stereoselective hydroxyl radical adduct formation in biological systems. Bioorg. Med. Chem. 2011, 19, 2218-2230.

[53] Khan, N.; Wilmot, C. M.; Rosen, G. M.; Demidenko, E.; Sun, J.; Joseph, J.; O’Hara, J.; Kalyanaraman, B.; Swartz, H. M. Spin traps: in vitro toxicity and stability of radical adducts. Free Radic. Biol. Med. 2003, 34, 1473-1481. 
[54] Rohr-Udilova, N.; Stolze, K.; Sagmeister, S.; Parzefall, W.; Marian, B.; Nohl, H.; SchulteHermann, R.; Grasl-Kraupp, B. Cytotoxicity of the novel spin trapping compound 5-ethoxycarbonyl3,5-dimethyl-pyrroline $\mathrm{N}$-oxide (3,5-EDPO) and its derivatives. Bioorg. Med. Chem. Lett. 2007, 17, $5698-5703$.

[55] Li, N.; Liu, J. H.; Zhang, J.; Yu, B. Y. Comparative evaluation of cytotoxicity and antioxidative activity of 20 flavonoids. J. Agric. Food Chem. 2008, 56, 3876-3883.

[56] Bouzaiene, N. N.; Jaziri, S. K.; Kovacic, H.; Chekir-Ghedira, L.; Ghedira, K.; Luis, J. The effects of caffeic, coumaric and ferulic acids on proliferation, superoxide production, adhesion and migration of human tumor cells in vitro. Eur. J. Pharmacol. 2015, 766, 99-105.

[57] Anderson, D. E.; Yuan, X. J.; Tseng, C. M; Rubin, L. J.; Rosen, G. M.; Tod, M. L. Nitrone spintraps block calcium channels and induce pulmonary artery relaxation independent of free radicals. Biochem. Biophys. Res. Commun. 1993, 193, 878-885.

[58] Chan, E. C. H.; Drummond, G. R.; Woodman, O. L. 3',4'-dihydroxyflavonol enhances nitric oxide bioavailability and improves vascular function after ischemia and reperfusion injury in the rat. $J$. Cardiovasc. Pharmacol. 2003, 42, 727-735.

[59] Pérez-Vizcaino, F.; Ibarra, M.; Cogolludo, A. L.; Duarte, J.; Zaragoza-Arnaez, F.; Moreno, L.; Lopez-Lopez, G.; Tamargo, J. Endothelium-independent vasodilator effects of the flavonoid quercetin and its methylated metabolites in rat conductance and resistance arteries. J. Pharmacol. Exp. Ther. 2002, $302,66-72$.

[60] Fukuda, T.; Kuroda, T.; Kono, M.; Hyoguchi, M.; Tanaka, M.; Matsui, T. Augmentation of ferulic acid-induced vasorelaxation with aging and its structure importance in thoracic aorta of spontaneously hypertensive rats. Naunyn Schmiedebergs Arch. Pharmacol. 2015, 388, 1113-1117. 
[61] Steffen, Y.; Gruber, C.; Schewe, T.; Sies, H. Mono-O-methylated flavonols and other flavonoids as inhibitors of endothial NADPH oxidase. Arch. Biochem. Biophys. 2008, 469, 209-219.

[62] Stocker, P.; Ricquebourg, E.; Vidal, N.; Villard, C.; Lafitte, L.; Sellami, L.; Pietri, S. Fluorimetric screening assay for protein carbonyl evaluation in biological samples. Anal. Biochem. 2015, 482, 55-61.

[63] Yap, S.; Loft, K. J.; Woodman, O. L.; Williams, S. J. Discovery of water-soluble antioxidant flavonols without vasorelaxant activity. ChemMedChem 2008, 3, 1572-1579.

[64] Atamna, H.; Paler-Martinez, A.; Ames, B. N-t-butyl hydroxylamine, a hydrolysis product of $\alpha$ phenyl- $N$-t-butyl nitrone, s more potent in delaying senescence in human lung fibroblasts. J. Biol. Chem. $\mathbf{2 0 0 0}, 275,6741-6748$.

[65] Burkitt, M. J.; Mason R. P. Direct evidence for in vivo hydroxyl-radical generation in experimental iron overload: an ESR spin-trapping investigation. Proc. Natl. Acad. Sci. USA 1991, 88, $8440-8444$.

[66] Takac, I.; Schröder, K.; Zhang, L.; Lardy,B.; Anilkumar, N.; Lambeth, J. D.; Shah, A. M.; Morel, F.; Brandes, R. P. The E-loop is involved in hydrogen peroxide formation by the NADPH oxidase Nox4. J. Biol. Chem. 2011, 286, 13303-13313.

[67] Souza, H. P.; Liu, X.; Samouilov, A.; Kuppusamy, P.; Laurindo, F. R. M.; Zweier, J. L. Quantitation of superoxide generation and substrate utilization by vascular NAD(P)H oxidase. Am. J. Physiol., Heart, Circ. Physiol. 2002, 282, H466-H474.

[68] Petrov, K. A.; Chauzov, V. A.; Pastukhova, I. V.; Bogdanov, N. N. Nitroalkyl organophosphorus compounds. II. Synthesis and properties of ( $\alpha$-nitroisoalkyl)phosphonates. Zh. Obshch. Khim. 1976, 46, 1246-1250. ibid. J. Gen. Chem., USSR (Engl. Transl.) 1976, 46, 1226-1229. 
[69] Martel, S.; Clément, J. L.; Muller, A.; Culcasi, M.; Pietri, S. Synthesis and ${ }^{31} \mathrm{P}$ NMR characterization of new low toxic highly sensitive $\mathrm{pH}$ probes designed for in vivo acidic $\mathrm{pH}$ studies. Bioorg. Med. Chem. 2002, 10, 1451-1458.

[70] Shinobu, L. A.; Jones, S. G.; Jones, M. M. Sodium $N$-methyl- $D$-glucamine dithiocarbamate and cadmium intoxication. Acta Pharmacol. Toxicol. (Copenh.) 1984, 54, 189-194.

[71] Petrov, K. A.; Treshchalina, L. V.; Chizhov, V. M. Hydroxyamino phosphonates. IV. Synthesis and properties of $\alpha$-(hydroxyamino) phosphonates Zh. Obshch. Khim. 1979, 49, 590-596. ibid. J. Gen. Chem., USSR (Engl. Transl.) 1979, 49, 516-521.

[72] Rockenbauer, A; Korecz, L. Automatic computer simulations of ESR spectra. Appl. Magn. Reson. 1996, 10, 29-43. 
Table 1. Selected Crystallographic Data of PPNs ${ }^{a}$

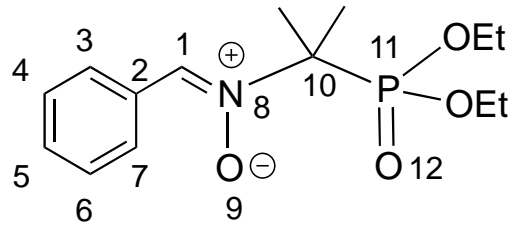

PPNs $\quad$ Bond lengths $(\AA) \quad$ Dihedral angles $\left(^{\circ}\right)$

$\overline{\mathrm{C}(1)-\mathrm{C}(2) \quad \mathrm{C}(1)-\mathrm{N}(8)} \quad \overline{\mathrm{O}(9)-\mathrm{N}(8)-\mathrm{C}(10)-\mathrm{P}(11) \quad \mathrm{N}(8)-\mathrm{C}(1)-\mathrm{C}(2)-\mathrm{C}(3)}$

\begin{tabular}{lrrrr}
$\mathbf{4 b}$ & $1.446(5)$ & $1.302(5)$ & $-91.4(0)$ & $1.3(3)$ \\
$\mathbf{4 f ^ { b }}$ & $1.445(7)$ & $1.297(6)$ & $-72.1(1)$ & $17.5(7)$ \\
$\mathbf{4 f ^ { b }}$ & $1.445(7)$ & $1.297(6)$ & $-72.1(3)$ & $17.2(5)$ \\
$\mathbf{4 k}$ & $1.448(5)$ & $1.312(5)$ & $64.9(2)$ & $3.3(1)$ \\
$\mathbf{4 q}$ & $1.471(3)$ & $1.293(2)$ & $-42.4(4)$ & $-111.4(6)$ \\
$\mathbf{4} \mathbf{c}^{c}$ & $1.448(3)$ & $1.302(3)$ & 67.3 & 0.4 \\
\hline
\end{tabular}

${ }^{a}$ Values in parentheses are the estimated SD. ${ }^{b}$ Represent the geometries of the two structures packed in the crystal lattice (Supporting Information, Figure S1B-D). ${ }^{\mathrm{c}}$ Data from Ref [32]. 
Table 2. Hyperfine Splitting Constants (hfscs) of Different Radical Adducts of Various Hydroxy and Methoxy Substituted PPNs

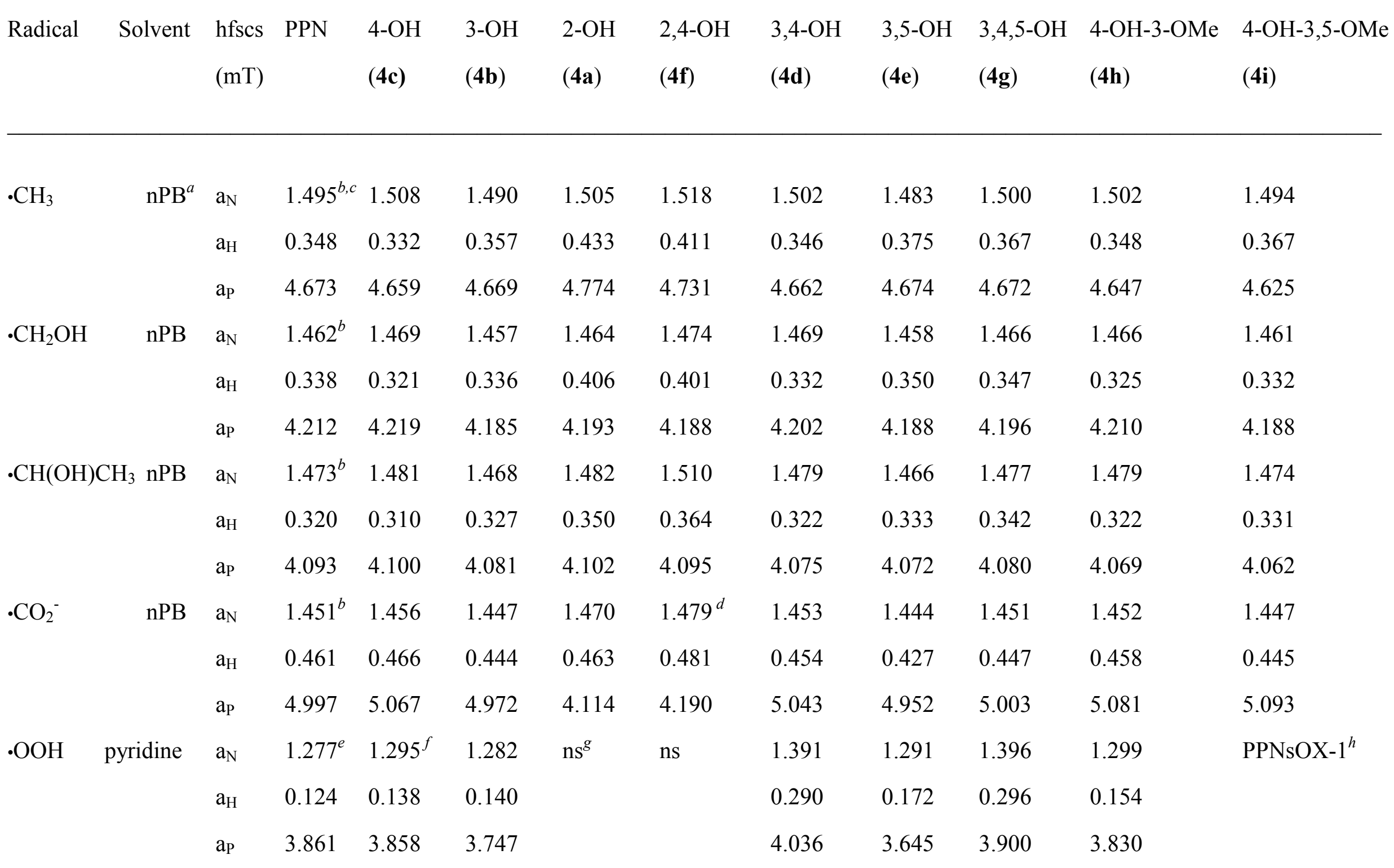




\begin{tabular}{|c|c|c|c|c|c|c|c|c|c|c|c|c|}
\hline \multirow[t]{3}{*}{$\cdot \mathrm{OCH}_{3}$} & DMSO & $a_{N}$ & $1.319^{i}$ & $1.338^{f}$ & 1.321 & 1.356 & 1.371 & 1.289 & 1.325 & $\mathrm{PPNsOX}-2^{h}$ & 1.307 & PPNsOX- $3^{h}$ \\
\hline & & $\mathrm{a}_{\mathrm{H}}$ & 0.248 & 0.280 & 0.273 & 0.344 & 0.367 & 0.185 & 0.297 & & 0.285 & \\
\hline & & $a_{P}$ & 3.899 & 3.921 & 3.847 & 3.983 & 4.014 & $3.967^{j}$ & 3.852 & & 4.017 & \\
\hline \multirow[t]{3}{*}{$\cdot \mathrm{SO}_{3}^{-}$} & $\mathrm{nPB}$ & $a_{N}$ & 1.365 & 1.375 & 1.362 & 1.373 & 1.378 & 1.373 & 1.358 & ns & 1.372 & 1.366 \\
\hline & & $a_{H}$ & 0.133 & 0.129 & 0.128 & 0.148 & 0.137 & 0.122 & 0.123 & & 0.121 & 0.120 \\
\hline & & $a_{P}$ & 4.354 & 4.442 & 4.366 & 4.255 & 4.311 & 4.440 & 4.394 & & 4.462 & 4.479 \\
\hline
\end{tabular}

${ }^{a} \mathrm{nPB}=$ phosphate buffer, $\mathrm{pH} 7.4{ }^{b}$ Data $(\mathrm{mT})$ from Ref. [29] in phosphate buffer, pH 7.0: PPN-CH $\mathrm{C}_{\mathrm{N}}=1.50 ; \mathrm{a}_{\mathrm{H}}=0.36 ; \mathrm{a}_{\mathrm{P}}=4.69 ; \mathrm{PPN}-$

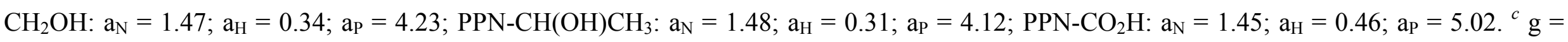
2.00550 (this work). ${ }^{d} \mathrm{~g}=2.00546$ (this work). ${ }^{e}$ Data from Ref. [29] in pyridine: $\mathrm{a}_{\mathrm{N}}=1.26 ; \mathrm{a}_{\mathrm{H}}=0.12 ; \mathrm{a}_{\mathrm{P}}=3.85 \mathrm{mT} .{ }^{f} \mathrm{Data}(\mathrm{mT})$ from Ref. $[32]$ : $4-$ OH-PPN-OOH in pyridine: $\mathrm{a}_{\mathrm{N}}=1.31 ; \mathrm{a}_{\mathrm{H}}=0.16 ; \mathrm{a}_{\mathrm{P}}=3.86$, and 4-OH-PPN-OCH 3 in DMSO: $\mathrm{a}_{\mathrm{N}}=1.34 ; \mathrm{a}_{\mathrm{H}}=0.28 ; \mathrm{a}_{\mathrm{P}}=3.89 .{ }^{g} \mathrm{~ns}=$ no signal. ${ }^{h}$ Decomposition signal assigned to the benzoyl nitroxide $(\mathrm{PPNsOX})$, i.e., $\operatorname{ArC}(\mathrm{O})-\mathrm{N}\left(\mathrm{O} \bullet-\mathrm{C}\left(\mathrm{Me}_{2}\right)-\mathrm{P}(\mathrm{O})(\mathrm{OEt})_{2} ; \mathrm{hfscs}(\mathrm{mT}): \mathrm{PPNsOX}-1\right.$ : $\mathrm{a}_{\mathrm{N}}=$ $0.500 ; \mathrm{a}_{\mathrm{P}}=0.932 ; \mathrm{a}_{\mathrm{H}}=0.371(2 \mathrm{H}), 0.177(6 \mathrm{H}), 0.090 ; \mathrm{PPNsOX}-2: \mathrm{a}_{\mathrm{N}}=0.245 ; \mathrm{a}_{\mathrm{P}}=0.772 ; \mathrm{a}_{\mathrm{H}}=0.241(2 \mathrm{H}), 0.103(1 \mathrm{H}), 0.040(2 \mathrm{H}) ; \mathrm{PPNsOX}-3: \mathrm{a}_{\mathrm{N}}$ $\left.=0.449 ; \mathrm{a}_{\mathrm{P}}=1.406 ; \mathrm{a}_{\mathrm{H}}=0.222(2 \mathrm{H}), 0.117\right) .{ }^{i}$ Data from Ref. [34] in water/methanol $(80: 20): \mathrm{a}_{\mathrm{N}}=1.38 ; \mathrm{a}_{\mathrm{H}}=0.33 ; \mathrm{a}_{\mathrm{P}}=3.99 \mathrm{mT} .{ }^{j} \mathrm{~A}$ satisfactory fit was obtained assuming a mixture of the expected methoxy radical adduct $(36 \%)$ and the corresponding PPNsOX (62\%) having the hfscs: $\mathrm{a}_{\mathrm{N}}=$ $0.526 ; \mathrm{a}_{\mathrm{P}}=0.705 ; \mathrm{a}_{\mathrm{H}}=0.438(2 \mathrm{H}), 0.355,0.192,0.082 \mathrm{mT}$. 
Table 3. EPR Parameters of Different Radical Adducts of 4-Chloro, 2-Trifluoromethyl and Various Nitro and Carboxy Substituted PPNs

\begin{tabular}{|c|c|c|c|c|c|c|c|c|c|c|}
\hline Radical & Solvent & $\begin{array}{l}\text { hfscs } \\
(\mathrm{mT})\end{array}$ & $\begin{array}{l}4-\mathrm{Cl} \\
(4 \mathbf{r})\end{array}$ & $\begin{array}{l}4-\mathrm{NO}_{2} \\
(4 \mathrm{I})\end{array}$ & $\begin{array}{l}3-\mathrm{NO}_{2} \\
(\mathbf{4 k})\end{array}$ & $\begin{array}{l}2-\mathrm{NO}_{2} \\
(\mathbf{4 j})\end{array}$ & $\begin{array}{l}\text { 4-AcNH } \\
(4 \mathrm{~m})\end{array}$ & $\begin{array}{l}4-\mathrm{CO}_{2} \mathrm{H} \\
(4 \mathbf{n})\end{array}$ & $\begin{array}{l}\text { 4- } \mathrm{CO}_{2} \mathrm{Et} \\
(\mathbf{4 o})\end{array}$ & $\begin{array}{l}2-\mathrm{CF}_{3} \\
(\mathbf{4 p )}\end{array}$ \\
\hline \multirow[t]{3}{*}{$\cdot \mathrm{CH}_{3}$} & $\mathrm{nPB}^{a}$ & $a_{N}$ & $1.488^{b}$ & $1.465^{c}$ & 1.471 & 1.453 & 1.490 & 1.479 & 1.475 & 1.476 \\
\hline & & $\mathrm{a}_{\mathrm{H}}$ & 0.314 & 0.294 & 0.267 & 0.469 & 0.317 & 0.329 & 0.326 & 0.580 \\
\hline & & $a_{p}$ & 4.643 & 4.644 & 4.660 & 4.765 & 4.658 & 4.657 & $4.634^{d}$ & 5.016 \\
\hline \multirow[t]{3}{*}{ - $\mathrm{CH}_{2} \mathrm{OH}$} & $\mathrm{nPB}$ & $a_{N}$ & $1.454^{b}$ & $1.434^{c}$ & 1.434 & 1.420 & 1.454 & 1.445 & 1.439 & 1.430 \\
\hline & & $\mathrm{a}_{\mathrm{H}}$ & 0.293 & 0.278 & 0.247 & 0.379 & 0.312 & 0.303 & 0.293 & 0.501 \\
\hline & & $a_{P}$ & 4.256 & 4.326 & 4.394 & 4.308 & 4.259 & 4.267 & 4.248 & 4.342 \\
\hline \multirow[t]{3}{*}{$\cdot \mathrm{CH}(\mathrm{OH}) \mathrm{CH}_{3}$} & $\mathrm{nPB}$ & $a_{N}$ & $1.465^{b}$ & $1.439^{c}$ & 1.442 & 1.423 & 1.469 & 1.454 & 1.451 & 1.430 \\
\hline & & $\mathrm{a}_{\mathrm{H}}$ & 0.308 & 0.268 & 0.247 & 0.327 & 0.303 & 0.296 & 0.280 & 0.367 \\
\hline & & $a_{p}$ & 4.130 & 4.198 & 4.316 & 4.474 & 4.119 & 4.152 & 4.101 & 4.142 \\
\hline \multirow[t]{3}{*}{$\cdot \mathrm{CO}_{2}^{-}$} & $\mathrm{nPB}$ & $a_{N}$ & $1.448^{b, e}$ & $1.434^{c}$ & 1.435 & 1.426 & 1.451 & 1.441 & 1.441 & 1.472 \\
\hline & & $\mathrm{a}_{\mathrm{H}}$ & 0.425 & 0.370 & 0.364 & 0.327 & 0.442 & 0.406 & 0.403 & 0.536 \\
\hline & & $a_{p}$ & 5.013 & 4.947 & 5.052 & 3.876 & 5.021 & 4.949 & 4.952 & 3.842 \\
\hline \multirow[t]{3}{*}{$\cdot \mathrm{OOH}$} & pyridine & $a_{N}$ & $\mathrm{~ns}^{f, g}$ & $1.247^{h}$ & 1.251 & 1.251 & 1.291 & 1.261 & ns & $\mathrm{ns}$ \\
\hline & & $\mathrm{a}_{\mathrm{H}}$ & & 0.112 & 0.106 & 0.174 & 0.141 & 0.117 & & \\
\hline & & $a_{P}$ & & 3.985 & 4.108 & 3.788 & 3.856 & 3.914 & & \\
\hline
\end{tabular}


Table 3 (continued 1)

\begin{tabular}{|c|c|c|c|c|c|c|c|c|c|c|}
\hline \multirow[t]{3}{*}{ •OOH } & water & $a_{N}$ & 1.357 & 1.333 & 1.366 & 1.333 & 1.312 & 1.346 & 1.348 & 1.356 \\
\hline & & $a_{H}$ & 0.200 & 0.168 & 0.235 & 0.307 & 0.179 & 0.196 & 0.188 & 0.444 \\
\hline & & $a_{P}$ & 4.230 & 4.212 & 4.173 & 4.015 & 4.232 & 4.195 & 4.201 & 4.411 \\
\hline \multirow[t]{3}{*}{$\cdot \mathrm{OCH}_{3}$} & DMSO & $a_{N}$ & $1.308^{i}$ & 1.296 & 1.297 & 1.283 & 1.268 & 1.311 & 1.300 & 1.308 \\
\hline & & $a_{H}$ & 0.231 & 0.195 & 0.195 & 0.335 & 0.135 & 0.229 & 0.234 & 0.527 \\
\hline & & $a_{P}$ & 3.900 & 4.027 & 4.027 & 3.823 & 4.062 & 3.824 & 3.887 & $4.308^{j}$ \\
\hline \multirow[t]{3}{*}{$\cdot \mathrm{SO}_{3}^{-}$} & $\mathrm{nPB}$ & $a_{N}$ & 1.362 & 1.333 & 1.331 & 1.332 & 1.367 & 1.361 & 1.354 & 1.341 \\
\hline & & $a_{H}$ & 0.121 & 0.168 & 0.226 & 0.197 & 0.125 & 0.123 & 0.114 & 0.175 \\
\hline & & $a_{P}$ & 4.467 & 3.978 & 4.338 & 4.564 & 4.441 & 4.439 & 4.466 & 3.990 \\
\hline \multirow[t]{3}{*}{$\cdot \mathrm{OH}$} & $\mathrm{acPB}^{a}$ & $a_{N}$ & $1.420^{b, k}$ & $1.402^{c, l}$ & $1.398^{m}$ & 1.426 & ns & $1.414^{n}$ & $1.409^{\circ}$ & $\mathrm{ns}$ \\
\hline & & $a_{H}$ & 0.219 & 0.192 & 0.178 & 0.361 & & 0.216 & 0.208 & \\
\hline & & $a_{P}$ & 4.339 & 4.288 & 4.369 & 3.936 & & 4.308 & 4.300 & \\
\hline \multirow[t]{4}{*}{$\cdot \mathrm{N}_{3}$} & $\mathrm{nPB}$ & $a_{N}$ & 1.392 & 1.370 & 1.368 & ns & ns & 1.388 & 1.381 & ns \\
\hline & & $a_{H}$ & 0.173 & 0.183 & 0.162 & & & 0.200 & 0.188 & \\
\hline & & $a_{P}$ & 4.451 & 4.420 & 4.446 & & & 4.476 & 4.421 & \\
\hline & & $a_{N \beta}$ & 0.187 & 0.192 & 0.201 & & & 0.182 & 0.180 & \\
\hline \multirow[t]{3}{*}{$\cdot H$} & water & $a_{N}$ & $\mathrm{~ns}$ & $1.508^{c}$ & 1.506 & 1.545 & ns & 1.525 & 1.512 & ns \\
\hline & & $a_{H}$ & & $1.042(2 \mathrm{H})$ & $1.065(2 \mathrm{H})$ & $1.325(2 \mathrm{H})$ & & $1.037(2 \mathrm{H})$ & $1.029(2 \mathrm{H})$ & \\
\hline & & $a_{P}$ & & 4.798 & 4.819 & 4.879 & & 4.846 & 4.816 & \\
\hline
\end{tabular}


${ }^{a}$ Phosphate buffer, $\mathrm{pH} 7.4(\mathrm{nPB})$ or $\mathrm{pH} 4.1-4.5(\mathrm{acPB}) .{ }^{b}$ Data $(\mathrm{mT})$ from Ref. [29] in phosphate buffer, $\mathrm{pH}$ 7.0: 4-Cl-PPN-CH${ }_{3}: \mathrm{a}_{\mathrm{N}}=1.50$; $\mathrm{a}_{\mathrm{H}}=$ 0.33; $\mathrm{a}_{\mathrm{P}}=4.67 ; 4-\mathrm{Cl}-\mathrm{PPN}-\mathrm{CH}_{2} \mathrm{OH}: \mathrm{a}_{\mathrm{N}}=1.47 ; \mathrm{a}_{\mathrm{H}}=0.31 ; \mathrm{a}_{\mathrm{P}}=4.34 ; 4-\mathrm{Cl}-\mathrm{PPN}-\mathrm{CH}(\mathrm{OH}) \mathrm{CH}_{3}: \mathrm{a}_{\mathrm{N}}=1.47 ; \mathrm{a}_{\mathrm{H}}=0.30 ; \mathrm{a}_{\mathrm{P}}=4.20 ; 4-\mathrm{Cl}-\mathrm{PPN}-\mathrm{CO} \mathrm{H}_{2} \mathrm{a}_{\mathrm{N}}=$ $1.46 ; \mathrm{a}_{\mathrm{H}}=0.42 ; \mathrm{a}_{\mathrm{P}}=5.02 ; 4-\mathrm{Cl}-\mathrm{PPN}-\mathrm{OH}: \mathrm{a}_{\mathrm{N}}=1.45 ; \mathrm{a}_{\mathrm{H}}=0.23 ; \mathrm{a}_{\mathrm{P}}=4.36 .{ }^{c}$ Data $(\mathrm{mT})$ from Ref. [30] in water: 4-NO${ }_{2}-\mathrm{PPN}-\mathrm{CH}_{3}: \mathrm{a}_{\mathrm{N}}=1.455 ; \mathrm{a}_{\mathrm{H}}=$ $0.307 ; \mathrm{a}_{\mathrm{P}}=4.633 ; 4-\mathrm{NO}_{2}-\mathrm{PPN}-\mathrm{CH}_{2} \mathrm{OH}: \mathrm{a}_{\mathrm{N}}=1.435 ; \mathrm{a}_{\mathrm{H}}=0.287 ; \mathrm{a}_{\mathrm{P}}=4.305 ; 4-\mathrm{NO}_{2}-\mathrm{PPN}-\mathrm{CH}(\mathrm{OH}) \mathrm{CH}_{3}: \mathrm{a}_{\mathrm{N}}=1.449 ; \mathrm{a}_{\mathrm{H}}=0.264 ; \mathrm{a}_{\mathrm{P}}=4.279 ; 4-\mathrm{NO}_{2}-$ PPN-CO ${ }_{2} \mathrm{H}: \mathrm{a}_{\mathrm{N}}=1.414 ; \mathrm{a}_{\mathrm{H}}=0.350 ; \mathrm{a}_{\mathrm{P}}=4.919 ; 4-\mathrm{NO}_{2}-\mathrm{PPN}-\mathrm{OH}: \mathrm{a}_{\mathrm{N}}=1.440 ; \mathrm{a}_{\mathrm{H}}=0.228 ; \mathrm{a}_{\mathrm{P}}=4.742 ; 4-\mathrm{NO}_{2}-\mathrm{PPN}-\mathrm{H}: \mathrm{a}_{\mathrm{N}}=1.507 ; \mathrm{a}_{\mathrm{H}}(2 \mathrm{H})=1.039 ;$ $\mathrm{a}_{\mathrm{P}}=4.794 .{ }^{d} \mathrm{~g}=2.00549$ (this work). ${ }^{e} \mathrm{~g}=2.00543$ (this work). ${ }^{f} \mathrm{~ns}=$ no signal. ${ }^{g}$ Data (mT) from Ref. [30]: 4-Cl-PPN-OOH in pyridine: $\mathrm{a}_{\mathrm{N}}=1.27$; $\mathrm{a}_{\mathrm{H}}=0.12 ; \mathrm{a}_{\mathrm{P}}=3.96 .{ }^{i}$ Data from Ref. [34] in water/methanol (80:20): $\mathrm{a}_{\mathrm{N}}=1.38 ; \mathrm{a}_{\mathrm{H}}=0.32 ; \mathrm{a}_{\mathrm{P}}=4.17 \mathrm{mT}$. g-values (this work): ${ }^{h} 2.00598 ;{ }^{j} 2.00581$; ${ }^{k} 2.00564 ;{ }^{l} 2.00568 ;{ }^{m} 2.00566 ;{ }^{n} 2.00568 ;{ }^{o} 2.00565$. 
Table 4. In Vitro Antioxidant Properties ${ }^{a}$ and Predicted Lipophilicity of PPNs Compared to Reference Compounds

\begin{tabular}{|c|c|c|c|c|}
\hline Compound & $\begin{array}{l}\mathrm{DPPH} \\
\mathrm{EC}_{50}(\mu \mathrm{M})\end{array}$ & $\begin{array}{l}\text { TRAP } \\
(\mathrm{TE})^{d}\end{array}$ & $\begin{array}{l}\text { superoxide quenching }^{b} \\
\qquad \mathrm{IC}_{50}(\mu \mathrm{M})\end{array}$ & $\mathrm{A} \log \mathrm{P}^{c}$ \\
\hline PPN & $>1000$ & $\sim 0.02$ & $375.0 \pm 26.8$ & 1.65 \\
\hline 2-OH-PPN 4a & $>1000$ & $0.25 \pm 0.06$ & $33.5 \pm 2.6$ & 1.30 \\
\hline 3-OH-PPN 4b & $>1000$ & $0.10 \pm 0.02$ & $123.0 \pm 6.5$ & 1.32 \\
\hline 4-OH-PPN 4c & $>1000$ & $0.65 \pm 0.06$ & $60.8 \pm 1.9$ & 1.33 \\
\hline 3,4-OH-PPN 4d & $22 \pm 1$ & $2.22 \pm 0.16$ & $0.2 \pm 0.1$ & 1.26 \\
\hline 3,5-OH-PPN 4e & $>1000$ & $0.70 \pm 0.04$ & $187.0 \pm 14.9$ & 1.26 \\
\hline 2,4-OH-PPN $\mathbf{4 f}$ & $>1000$ & $1.61 \pm 0.15$ & $43.3 \pm 3.9$ & 1.25 \\
\hline 3,4,5-OH-PPN 4g & $19 \pm 1$ & $1.46 \pm 0.09$ & $0.9 \pm 0.1$ & 0.94 \\
\hline 4-OH-3-OMe-PPN $\mathbf{4 h}$ & $254 \pm 9$ & $1.91 \pm 0.10$ & $28.6 \pm 1.1$ & 1.39 \\
\hline 4-OH-3,5-OMe-PPN 4i & $190 \pm 11$ & $1.44 \pm 0.13$ & $72.1 \pm 3.9$ & 1.40 \\
\hline $2-\mathrm{NO}_{2}-\mathrm{PPN} \quad \mathbf{4 j}$ & $>1000$ & $\sim 0.02$ & $30.0 \pm 1.5$ & 1.63 \\
\hline $3-\mathrm{NO}_{2}-\mathrm{PPN} \quad 4 \mathbf{k}$ & $>1000$ & $\sim 0.02$ & $52.3 \pm 2.9$ & 1.63 \\
\hline $4-\mathrm{NO}_{2}-\mathrm{PPN} 4 \mathbf{l}$ & $>1000$ & $\sim 0.02$ & $9.3 \pm 0.3$ & 1.65 \\
\hline 4-AcNH-PPN 4m & $>1000$ & $\sim 0.02$ & $26.3 \pm 5.0$ & 1.39 \\
\hline 4- $\mathrm{CO}_{2} \mathrm{H}-\mathrm{PPN} \quad 4 \mathbf{n}$ & $>1000$ & $\sim 0.02$ & $4.1 \pm 0.1$ & 1.28 \\
\hline 4- $\mathrm{CO}_{2}$ Et-PPN $4 \mathbf{o}$ & $>1000$ & $0.16 \pm 0.02$ & $6.8 \pm 0.3$ & 2.00 \\
\hline $2-\mathrm{CF}_{3}-\mathrm{PPN} \mathbf{4 p}$ & $>1000$ & $\sim 0.02$ & $4.2 \pm 0.2$ & 2.34 \\
\hline 2,6-Me-PPN 4q & $>1000$ & $\sim 0.02$ & $350.2 \pm 12.8$ & 1.98 \\
\hline PBN & $>1000$ & $\sim 0.02$ & $>4000$ & 1.40 \\
\hline & $7 \pm 1$ & $1.18 \pm 0.07$ & $0.7 \pm 0.2$ & 1.17 \\
\hline
\end{tabular}

Gallic acid 


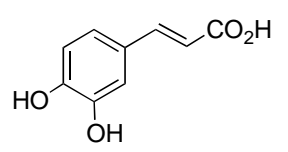
$17 \pm 1$
$2.73 \pm 0.13$
$0.1 \pm 0.0$
1.25

Caffeic acid

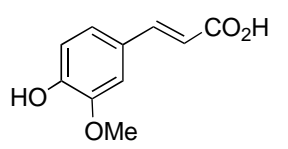
$61 \pm 4$
$2.16 \pm 0.15$
$34.9 \pm 0.7$
1.58

Ferulic acid<smiles>COc1cc(C=CC(=O)O)cc(OC)c1O</smiles>
$35 \pm 1$
$1.64 \pm 0.10$
$22.4 \pm 0.5$
1.63

Sinapic acid

Trolox

$20 \pm 1$

1.00

$13.3 \pm 1.1 \quad 2.73$

Quercetin

$13 \pm 2$

$6.28 \pm 0.06$

$0.5 \pm 0.1$

1.81

${ }^{a}$ Experimental details are given in Supporting Information. Data are means \pm SEM of 3-10 independent experiments made in triplicate. ${ }^{b}$ Superoxide generator was the allopurinol-xanthine oxidase system and scavenging activity was determined by assaying lucigenin chemiluminescence. ${ }^{c}$ Obtained by using the ALOGPS 2.1 software (www.vcclab.org/lab/alogps/). ${ }^{d}$ TE, equivalent Trolox; TRAP $\sim 0.02$ for inactive compounds. 
Table 5. Effect of Selected PPNs and Related Compounds on Cytotoxicity Against A549 Cells ${ }^{a}$ and Potencies for Relaxation to SNP of Endothelium-Intact Rat Aortic Rings ${ }^{b}$

\begin{tabular}{|c|c|c|c|c|c|c|}
\hline \multirow[t]{3}{*}{ Compound } & \multicolumn{4}{|c|}{ Cytotoxicity assay } & \multicolumn{2}{|c|}{ Response to SNP } \\
\hline & FMCA & ATP & MTT & $\mathrm{LDH}$ & sensitivity & relaxation \\
\hline & \multicolumn{3}{|c|}{$\mathrm{IC}_{50}(\mathrm{mM})^{c}$} & $\Delta(\%)^{d}$ & $\mathrm{pEC}_{50}{ }^{e}$ & $R_{\max }(\%)^{\dagger}$ \\
\hline vehicle & 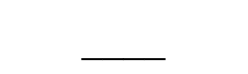 & 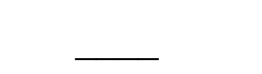 & 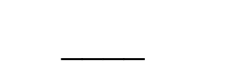 & 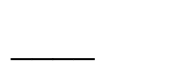 & $7.98 \pm 0.02$ & $99 \pm 3$ \\
\hline PPN & $13.58 \pm 0.12$ & $12.14 \pm 0.51$ & $13.03 \pm 0.42$ & $15 \pm 1 *$ & $8.54 \pm 0.06^{*}$ & $100 \pm 2$ \\
\hline PBN & $8.30 \pm 0.27$ & $9.32 \pm 0.29$ & $10.20 \pm 0.13$ & $18 \pm 2^{*}$ & $8.22 \pm 0.12$ & $98 \pm 2$ \\
\hline 2-OH-PPN 4a & $8.23 \pm 0.25$ & $9.25 \pm 0.19$ & $8.98 \pm 0.36$ & $17 \pm 2 *$ & $8.24 \pm 0.08$ & $99 \pm 2$ \\
\hline 3-OH-PPN 4b & $7.56 \pm 0.27$ & $8.25 \pm 0.21$ & $7.48 \pm 0.97$ & $19 \pm 2^{*}$ & $8.30 \pm 0.10$ & $99 \pm 2$ \\
\hline 4-OH-PPN 4c & $10.47 \pm 0.49$ & $12.36 \pm 0.31$ & $13.02 \pm 0.32$ & $12 \pm 4$ & $8.25 \pm 0.10$ & $99 \pm 2$ \\
\hline 3,4-OH-PPN 4d & $1.87 \pm 0.08$ & $1.92 \pm 0.16$ & $1.30 \pm 0.27$ & $28 \pm 3 * *$ & $9.01 \pm 0.06^{* *}$ & $103 \pm 3$ \\
\hline 3,5-OH-PPN $4 \mathbf{e}$ & $4.95 \pm 0.33$ & $6.98 \pm 0.25$ & $7.91 \pm 0.32$ & $14 \pm 2 *$ & $8.28 \pm 0.11$ & $98 \pm 4$ \\
\hline 3,4,5-OH-PPN $\mathbf{4 g}$ & $0.56 \pm 0.05$ & $0.63 \pm 0.08$ & $0.73 \pm 0.24$ & $36 \pm 3 * *$ & $8.98 \pm 0.11^{* *}$ & $104 \pm 3$ \\
\hline 4-OH-3-OMe-PPN $\mathbf{4 h}$ & $6.41 \pm 0.58$ & $4.32 \pm 0.29$ & $3.87 \pm 0.18$ & $19 \pm 3 *$ & $8.99 \pm 0.03 * *$ & $100 \pm 3$ \\
\hline
\end{tabular}


Table 5 (continued 1)

\begin{tabular}{|c|c|c|c|c|c|c|}
\hline 4-OH-3,5-OMe-PPN $\mathbf{4 i}$ & $12.01 \pm 0.47$ & $14.77 \pm 0.58$ & $15.33 \pm 0.18$ & $12 \pm 4^{*}$ & $8.66 \pm 0.04 *$ & $101 \pm 2$ \\
\hline $2-\mathrm{NO}_{2}-\mathrm{PPN} \quad \mathbf{4 j}$ & $2.20 \pm 0.07$ & $1.35 \pm 0.35$ & $1.33 \pm 0.75$ & $58 \pm 5^{* *}$ & $8.91 \pm 0.06^{*}$ & $100 \pm 2$ \\
\hline $4-\mathrm{NO}_{2}-\mathrm{PPN} 4 \mathbf{l}$ & $1.12 \pm 0.10$ & $0.95 \pm 0.07$ & $1.26 \pm 0.07$ & $54 \pm 6^{* *}$ & $8.37 \pm 0.05^{*}$ & $101 \pm 1$ \\
\hline $4-\mathrm{CO}_{2} \mathrm{H}-\mathrm{PPN} 4 \mathbf{n}$ & $7.83 \pm 1.04$ & $8.23 \pm 0.42$ & $7.28 \pm 0.75$ & $15 \pm 3 *$ & $\mathrm{nd}^{g}$ & nd \\
\hline 4- $\mathrm{CO}_{2} \mathrm{Et}-\mathrm{PPN} 4 \mathbf{o}$ & $4.53 \pm 0.28$ & $3.56 \pm 0.41$ & $3.51 \pm 0.38$ & nd & nd & nd \\
\hline $2-\mathrm{CF}_{3}-\mathrm{PPN} \mathbf{4 p}$ & $2.15 \pm 0.14$ & $2.71 \pm 0.18$ & $4.23 \pm 0.25$ & nd & $8.99 \pm 0.03 * *$ & $104 \pm 2$ \\
\hline 2,6-Me-PPN 4q & $4.74 \pm 0.36$ & $5.25 \pm 0.23$ & $4.41 \pm 0.36$ & nd & $9.03 \pm 0.04 * *$ & $105 \pm 3$ \\
\hline Gallic acid & $0.39 \pm 0.02$ & $0.39 \pm 0.01$ & $0.35 \pm 0.02$ & nd & nd & nd \\
\hline Caffeic acid & $0.49 \pm 0.15$ & $0.73 \pm 0.12$ & $0.67 \pm 0.10$ & nd & nd & nd \\
\hline Ferulic acid & $2.56 \pm 0.21$ & $3.23 \pm 0.09$ & $3.13 \pm 0.08$ & nd & nd & nd \\
\hline Sinapic acid & $4.56 \pm 0.13$ & $5.71 \pm 0.12$ & $4.88 \pm 0.10$ & nd & nd & nd \\
\hline
\end{tabular}

${ }^{a}$ Cells were seeded at $2.5 \times 10^{4}$ cells/well in DMEM until confluence and were then treated with compounds either at $0.01-30 \mathrm{mM}$ for $48 \mathrm{~h}$ or at $15 \mathrm{mM}$ for $3 \mathrm{~h}$ in $\left[\mathrm{DMEM}+0.5 \%\right.$ DMSO] (vehicle). Data are means $\pm \mathrm{SD}$ of $3-6$ independent experiments ${ }^{b}$ Rings were precontracted with $5 \times 10^{-6}$ $\mathrm{M}$ phenylephrine $(\mathrm{PE})$ and the response to SNP $\left(10^{-10}-10^{-4} \mathrm{M}\right)$ was measured in $[\mathrm{KH}+0.1 \% \mathrm{DMSO}]$ medium (vehicle) in the presence or absence of tested compounds $(200 \mu \mathrm{M}) .{ }^{c} \mathrm{IC}_{50}$ defined as the concentration of compound resulting in $50 \%$ cell viability after $48 \mathrm{~h}$ and calculated from concentration-response curves. ${ }^{d}$ Percentage of decrease of intracellular LDH content in cells treated with compounds at $15 \mathrm{mM}$ for $3 \mathrm{~h}$ vs vehicle. 
${ }^{e} \mathrm{pEC}_{50}$ defined as the $-\log$ concentration of SNP resulting in $50 \%$ inhibition of the maximum response to PE. ${ }^{f} \mathrm{R}_{\text {max }}$ defined as the calculated maximal relaxation response to SNP. ${ }^{g}$ nd $=$ not determined. One way-ANOVA followed by Newman-Keuls test: $* P<0.05$ and $* * P<0.01$ vs corresponding vehicle. 
Table 6. Effect of Nitrones $(200 \mu \mathrm{M})$ on the Potencies for Relaxation to ACh in Endothelium-Intact Rat Aortic Rings Exposed to Superoxide Radicals

\begin{tabular}{|c|c|c|}
\hline \multirow[t]{2}{*}{ Condition } & \multicolumn{2}{|c|}{ Response to $\mathrm{ACh}^{a}$} \\
\hline & $\mathrm{pEC}_{50}{ }^{b}$ & $R_{\max }(\%)^{c}$ \\
\hline vehicle & $7.66 \pm 0.06$ & $95 \pm 2$ \\
\hline vehicle $+\mathrm{O}_{2}{ }^{-}$ & $6.39 \pm 0.08 *$ & $56 \pm 2 *$ \\
\hline $\mathrm{PBN}+\mathrm{O}_{2}^{\bullet^{-}}$ & $6.76 \pm 0.22$ & $62 \pm 4$ \\
\hline $\mathrm{PPN}+\mathrm{O}_{2}^{\bullet^{-}}$ & $6.83 \pm 0.08$ & $75 \pm 2$ \\
\hline 3,4-OH-PPN 4d + $\mathrm{O}_{2}^{\bullet^{-}}$ & $7.39 \pm 0.05^{\S}$ & $93 \pm 1^{\S}$ \\
\hline 3,4,5-OH-PPN 4g $+\mathrm{O}_{2} \bullet^{-}$ & $7.55 \pm 0.05^{\S}$ & $93 \pm 1^{\S}$ \\
\hline 4-OH-3-OMe-PPN $\mathbf{4 h}+\mathrm{O}_{2}^{\cdot-}$ & $7.27 \pm 0.04^{\S}$ & $86 \pm 1^{\S}$ \\
\hline 4-OH-3,5-OMe-PPN 4i $+\mathrm{O}_{2}^{\bullet^{-}}$ & $7.17 \pm 0.08^{\S}$ & $77 \pm 2^{\S}$ \\
\hline
\end{tabular}

${ }^{a}$ Rings were exposed for $10 \mathrm{~min}$ to xanthine $(0.1 \mathrm{mM})$-xanthine oxidase $(10 \mathrm{mU} / \mathrm{mL})$ before precontraction with PE $\left(\sim 10^{-6} \mathrm{M}\right)$. The response to ACh $\left(10^{-9}-10^{-4} \mathrm{M}\right)$ was then determined in $[\mathrm{KH}+$ $0.1 \%$ DMSO] medium (vehicle) in the presence or absence of compounds. Data are means \pm SD of 6 independent experiments/group. ${ }^{b} \mathrm{pEC}_{50}$ defined as the $-\log$ concentration of $\mathrm{ACh}$ resulting in $50 \%$ inhibition of the maximum response to $\mathrm{PE} .{ }^{c} R_{\max }$ defined as the calculated maximal relaxation response to ACh. One-way ANOVA followed by Newman-Keuls test: ${ }^{*} P<0.05$ vs vehicle; ${ }^{\S} P<0.05$ vs vehicle $+\mathrm{O}_{2}{ }^{-}$ 